\title{
Localization and Functional Roles of Components of the Translation Apparatus in the Eukaryotic Cell Nucleus
}

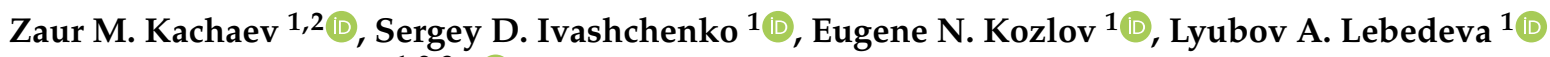 \\ and Yulii V. Shidlovskii $1,2,3, *$ (D) \\ 1 Department of Gene Expression Regulation in Development, Institute of Gene Biology, \\ Russian Academy of Sciences, 119334 Moscow, Russia; k-z-m@mail.ru (Z.M.K.); \\ ivashchenko.sd@phystech.edu (S.D.I.); ugin.sfu@gmail.com (E.N.K.); 1178@yandex.ru (L.A.L.) \\ 2 Center for Genetics and Life Science, Sirius University of Science and Technology, 354340 Sochi, Russia \\ 3 Department of Biology and General Genetics, Sechenov First Moscow State Medical University (Sechenov \\ University), 119992 Moscow, Russia \\ * Correspondence: yul.biogen@gmail.com
}

check for updates

Citation: Kachaev, Z.M.; Ivashchenko, S.D.; Kozlov, E.N.; Lebedeva, L.A.; Shidlovskii, Y.V. Localization and Functional Roles of Components of the Translation Apparatus in the Eukaryotic Cell Nucleus. Cells 2021, 10, 3239. https://doi.org/10.3390/ cells10113239

Academic Editor: Hiroshi Miyamoto

Received: 28 September 2021 Accepted: 16 November 2021 Published: 19 November 2021

Publisher's Note: MDPI stays neutral with regard to jurisdictional claims in published maps and institutional affiliations.

Copyright: (c) 2021 by the authors. Licensee MDPI, Basel, Switzerland. This article is an open access article distributed under the terms and conditions of the Creative Commons Attribution (CC BY) license (https:// creativecommons.org/licenses/by/ $4.0 /)$.

\begin{abstract}
Components of the translation apparatus, including ribosomal proteins, have been found in cell nuclei in various organisms. Components of the translation apparatus are involved in various nuclear processes, particularly those associated with genome integrity control and the nuclear stages of gene expression, such as transcription, mRNA processing, and mRNA export. Components of the translation apparatus control intranuclear trafficking; the nuclear import and export of RNA and proteins; and regulate the activity, stability, and functional recruitment of nuclear proteins. The nuclear translocation of these components is often involved in the cell response to stimulation and stress, in addition to playing critical roles in oncogenesis and viral infection. Many components of the translation apparatus are moonlighting proteins, involved in integral cell stress response and coupling of gene expression subprocesses. Thus, this phenomenon represents a significant interest for both basic and applied molecular biology. Here, we provide an overview of the current data regarding the molecular functions of translation factors and ribosomal proteins in the cell nucleus.
\end{abstract}

Keywords: translation factor; ribosomal protein; gene expression; nucleus; stress; cell response; transcription; mRNA export; cancer; moonlighting protein

\section{Introduction}

mRNA translation is performed by a large number of highly conserved proteins and RNAs. The main components of the translation apparatus (CTAs) include translation factors, ribosomal proteins (RPs), and ribosomal RNAs (rRNAs) [1]. The eukaryotic 80S ribosome consists of two subunits, the $40 \mathrm{~S}$ and the 60S. The large subunit contains three types of rRNA (28S, 5.8S, and 5S) and approximately 50 RPL proteins, whereas the small subunit consists of a single $18 \mathrm{~S}$ rRNA and approximately $30 \mathrm{RPS}$ proteins. The ribosome components are encoded by hundreds of copies of rRNA genes and dozens of RP genes, and most of the ribosome biogenesis steps occur in the nucleolus [2-4]. Ribosome biogenesis is an energy-consumptive process that is finely regulated by various signaling pathways, including the target of rapamycin (TOR) pathway [5-9].

The core group of proteins that govern translation includes initiation, elongation, and termination/release factors. Translation initiation factors are highly conserved and include the eukaryotic initiation factors (eIFs) eIF1, eIF1A, eIF1B, eIF2 (a complex consisting of three subunits; eIF2S1 is also known as eIF2 $\alpha$ ), eIF2A, eIF2B (a complex consisting of five subunits), eIF3 (a complex consisting of up to 13 subunits), eIF4A, eIF4B, eIF4E, eIF4G, eIF4H, eIF5, eIF5B, and auxiliary eIF6. The eukaryotic elongation factors (eEFs) include eEF1A, eEF1B (a complex consisting of two to four subunits), eEF2, eIF5A, and eEFSec. The eukaryotic release factors include eRF1 and eRF3. Some CTAs have several paralogs 
and isoforms. The functioning of the core apparatus is accompanied by other proteins, in addition to these factors $[1,10-16]$.

\section{Nuclear and Subnuclear Localization of Translation Factors and Its Regulation}

Initially, translation factors were thought to localize in the cytoplasm. In the 1990s, one of the first studies by N. Sonenberg reported that eIF4E was localized to the nuclei of COS-1 monkey cells [17], which was later found to be a conserved feature of this protein in other species $[18,19]$. Since then, hundreds of papers have described the nuclear localization of various CTAs, although in many cases, the functional roles associated with nuclear localization remain unclear and poorly explored.

Multiple screening studies have applied cell imaging or biochemical purification techniques to reveal the presence of translation factors in the nucleus. A localization screen of the YFP-tagged Saccharomyces pombe ORFeome revealed the nuclear or dual nuclear and cytoplasmic localization of eIF1A, eIF2S1, eIF2B1, eIF2B4, eIF3d, eIF3g, eIF3i, eIF5A1, eIF6, eEF1A-B, and eRF1 [20]. By contrast, an analysis of the GFP-tagged proteome in Saccharomyces cerevisiae revealed that only eIF6 was localized to the nucleus [21], although the nuclear localization of eIF4E in S. cerevisiae was described in a separate study [18]. In a screen of YFP-tagged Drosophila embryonic proteins, eIF1A showed nuclear localization [22].

The analysis of the nuclear proteome of Arabidopsis revealed the presence of eIF2S1 and several RPs in the nucleus. eIF2S1 and a set of RPs showed nuclear accumulation following cold stress, whereas another set of RPs showed the opposite behavior [23]. Another screen examining Arabidopsis protein localization identified the nuclear localization of eIF3f, eIF4E, eIF5, and eEF1A [24]. A recent analysis of the Arabidopsis nuclear proteome revealed additional CTAs with nuclear localization, and several RPs were found to be imported into the nucleus during the immune response $[25,26]$.

Systematic immunostaining analysis of human translation factor localization revealed the presence of eIF1, eIF1A, and eIF6 in the nucleus [27]. eIF1A was also found in the nucleus of human cells following the inhibition of importin-13 [28]. The human protein haponin (eIF1AD), which is paralogous to eIF1A, resides in the nucleus and is involved in the oxidative stress response [29]. eIF6 was found in the human nucleolus, where it participates in ribosome biogenesis [30]. The elongation factor eEFSec presents a dual nucleocytoplasmic localization and utilizes CRM1 (exportin 1)-mediated nuclear export pathway [31]. In Xenopus oocytes, the nucleoproteome includes eIF4E, eIF6, and eEFSec [32]. A recent analysis of the chromatin-associated proteome in mouse embryonic stem cells revealed the presence of an almost complete set of translation factors and RPs [33].

Several translation factors have been found in specific subnuclear compartments, including the nucleolus, nuclear bodies, and speckles, or colocalizing with specific proteins. eIF4A1, eIF6, and eEF1A were found in the nucleolus in Arabidopsis [34]. eRF1 was found in the nucleolus in yeast, where it likely participates in the quality control mechanisms of maturing ribosomes [35]. eIF3k directly interacts with the nuclear promyelocytic leukemia protein (PML), and its isoform eIF3k2 is localized in PML bodies in human cells [36]. In addition, eIF3k interacts with and partially colocalizes with cyclin D3 in the nuclei of human cells [37]. eIF3e was found in nuclear bodies in human primary lymphocytes [38]. eIF4E was found in nuclear speckles, which often colocalize with PML bodies in human cells [39].

Fractionation techniques have further confirmed the association of CTAs with subnuclear structures. The analysis of interchromatin granule cluster compositions from mouse liver nuclei revealed the presence of eIF4A and multiple RPs [40]. The sequential extraction of proteins from human cells to obtain a chromosome scaffold fraction revealed several RPs in this fraction [41]. Another study of human cells showed the presence of eIF4A1, eIF5A1, eIF6, eEF1A1, eEF1B $\gamma, \mathrm{eEF} 1 \varepsilon 1, \mathrm{eEF} 2$, and multiple RPs in the insoluble nuclear fraction, which contains nuclear architectural components [42].

Some of the interactomes reported for nuclear proteins also imply a nuclear localization for several CTAs. For example, the interactome reported for murine nuclear 
phosphoinositide-specific phospholipase $C \beta 1 \mathrm{~b}$ (PI-PLC $\beta 1 \mathrm{~b}$ ), which is involved in the regulation of cell division, revealed several RPs and subunits of eIF2, eIF3, eIF4A, eIF4B, eIF5A1, eIF5A2, and eEF1A [43]. In Drosophila, the interactions of eIF1A with the transcription factor (TF) Ssb-c31a, eIF5A with TF Mes2, eEF1B $\delta$ and eEF2 with the histone-associated factors nucleoplasmin and Df31 have been reported [44].

Certain CTAs could be components of several protein complexes and thus have specific nuclear functions. eIF3e/Int6 is a subunit shared with the proteasome and COP9 signalosome, which are involved in protein degradation [45,46]. In yeasts, eIF3e is required for a proper accumulation of proteasomes in the nucleus, which is crucial for the progression of the cell cycle $[47,48]$. eIF3e and eIF3c are also associated with the COP9 signalosome in Arabidopsis nuclei [49].

Several molecular mechanisms are employed in the cell to control nuclear localization of translation factors. The phosphorylation status appears to affect the localization. Mammalian eIF2S1 was found in the nucleus, and its localization depends on the phosphorylation [50-53]. An analysis of the nuclear phosphoproteome in HeLa cells revealed the presence of phosphorylated eIF2B5, eIF4B, eIF4G1, eIF4G2, eIF3b, eIF3c, eIF3g, eIF5B, RPS3, and RPLP0 [54].

The nuclear accumulation of eIF5A1 and eIF5A2 paralogs is regulated via acetylation, which is supervised by nuclear PCAF, HDAC6, and Sirtuin enzymes. The mutually opposite modification by hypusine determines their localization in the cytoplasm in mammalian cells [55-57]. eIF5A2 was also found in the nuclei of Arabidopsis cells [58,59]. In plants, phosphorylation by casein kinase 2 (CK2) plays a role in the regulation of eIF5A nucleocytoplasmic shuttling $[60,61]$. In mammals, the nuclear entry of eIF5A1 has been initially suggested to occur via passive diffusion [62], but an NLS was later identified in the N-terminus of the protein [63]. eIF5A1 export occurs with the help of exportin-1 or exportin-4, whereas eIF5A2 export requires exportin-4 [57,64].

Other proteins may control the intracellular localization of translation factors. The transport of human eIF4E to the nucleus depends on the eIF4E transporter 4E-T, a nucleocytoplasmic shuttle protein that contains an eIF4E-binding site. In the presence of a 4E-T transporter, the formation of an importin- $\alpha \beta$ heterodimer in a complex with eIF4E is possible $[65,66]$. Interestingly, in the nuclei of human cells, 4E-T colocalizes in PML-associated foci with another multifunctional factor, Pat1, which is also involved in translation control [67]. 4E-T also mediates the nuclear import of the translational repressor DDX6 in human cells [68] and serves as a general translation repressor [66]. In Drosophila, eIF4E interacts with the translation regulator cup, which is a shuttling protein, and this interaction is important for cup retention in the cytoplasm of ovarian cells [69].

Viral infection is one of the factors that affect the intracellular distribution of various CTAs. A fraction of eIF3e was found in PML bodies under normal conditions, whereas the binding of the human T-cell leukemia virus (HTLV-I) regulatory Tax protein with eIF3e causes its redistribution to the cytoplasm [70]. Contrary, eIF4A1 translocates to the nucleus and cooperates with the viral protein Rev to promote further Gag protein synthesis during HIV-1 replication in human cells [71]. Viral infection causes the strong nuclear accumulation of eIF4G in HeLa cells [72].

In addition to the core CTAs, other translational factors and translational regulators have been identified in the nucleus. The translation factor SLIP (MIF4GD), which is required for the replication-dependent translation of histone mRNAs, was found in both the nucleus and cytoplasm in human cells [73]. The translational repressor nanos3 was found in the nuclei of murine and human primordial germ cells $[74,75]$. The mTOR kinase, which acts as a general regulator of translation, was found in cell nuclei and has been associated with nuclear regulatory functions in human and murine cells [76,77]. The eIF2 $\alpha$ (eIF2S1) kinase 2 PKR was also found in the nuclei of acute leukemia cells [78]. 


\section{Regulation of RP Nuclear Localization}

RPs enter the nucleus to participate in rRNA maturation and ribosome assembly [79-81], and RPs are abundant in the nucleolus. Indeed, study of the interactome of the nucleolar protein Nop132 [82] and direct nucleolar proteome isolation revealed multiple RPs [83]. Moreover, RPL11 and RPL15 are significant contributors to the integrity of the nucleolar structure in human cells [84]. RPs feature a nuclear localization signal (NLS), which is commonly found in highly conserved rRNA-binding domains and appears to be involved in rRNA folding [85]. Other eukaryotic-specific sequences in RPs have also been identified as involved in the nuclear trafficking of RPs [86]. NLSs of several RPs define their localization not only in the nucleuolus, but also in the nucleoplasm $[87,88]$.

The various regulatory pathways and protein modifications mediate the nuclear and subnuclear localization of RPs [80,89-92]. The mTOR signaling pathway regulates the nuclear import of RPs in human cells [93]. RPL10B relocates to the nucleus upon UV irradiation in Arabidopsis [94]. The proper localization of RPS10 in the granular component of the nucleolus in human cells requires arginine methylation by protein arginine methyltransferase 5 (PRMT5) [95], whereas RPS3 transport to the nucleolus is dependent on arginine methylation by PRMT1 [96]. RPL3 in human cells is a substrate of nuclear methyltransferase-like 18 (METTL18); this modification is important for its role in ribosome biogenesis [97]. Modification by the small ubiquitin-like modifier protein (SUMO) regulates the nuclear localization of RPL22 in Drosophila meiotic spermatocytes [98].

Interaction with other molecules might affect the RP localization. Epstein-Barr virus (EBV) infection causes the relocalization of RPL22 in B lymphocytes via interactions between RPL22 and non-coding RNA [99,100]. The potato virus A causes the accumulation of several RPs in the nucleus [101]. By contrast, the rabies virus phosphoprotein interacts with RPL9, causing translocation from the nucleus to the cytoplasm in human cells [102]. The nucleolar localization of RPS9 in human cells depends on its interaction with the multifunctional protein nucleophosmin $[103,104]$. The tumor suppressor BCCIP $\beta$ interacts with RPS7 and modulates its extraribosomal functions in the nuclei of human cells [105]. BCCIP $\beta$ also forms a complex with nuclear RPL23 and eIF6 in human cells; this interaction stabilizes the nuclear pool of RPL23 [106]. The properties of a nuclear RPs could differ from those of their cytoplasmic counterparts; for example, not cytosolic but nuclear RPS3A specifically binds phosphatidylinositol trisphosphate second messenger in human cells [107].

RPs also contribute to the intranuclear localization of other proteins. RPL5 is abundant in the nucleolus in human cells, and its interaction with the nucleolar ATPase NVL2, which is involved in ribosome biogenesis, determines the specific nucleolar localization of NVL2 [88]. RPS3 or RPL19 are required for the nuclear localization of ERH protein in Drosophila [108]. RPL9 participates in the intranuclear trafficking of mammary tumor virus (MMTV) Gag protein [109]. RPL11 interacts with the nuclear protein PML and is important for the nucleolar localization of PML, which is induced by stress conditions in mammalian cells [110]. RPS6 interacts with the latency-associated nuclear antigen (LANA) of Kaposi's sarcoma-associated herpesvirus, contributing to its stability [111].

A component of the $40 \mathrm{~S}$ ribosomal subunit RACK1 is constitutively present in the nucleus of murine cells, where it is recruited into the BMAL1 complex in a circadian manner during the negative feedback phase of the circadian cycle [112]. RACK1 localization in the nucleus and interactions with eIF6 in both the cytoplasmic and nuclear compartments were also described in Arabidopsis [113].

CTAs have been found to be involved in multiple nuclear functions. We describe their key nuclear activities below.

\section{Roles for CTAs in DNA Repair, Synthesis, and Genome Integrity Control}

Several CTAs are essential components of the DNA damage response pathway. RPS3 is one of them. In response to genotoxic stress, RPS3 is translocated to the nucleus and recruited to the DNA damage loci in human cells. The translocation of RPS3 in the DNA damage response pathway is mediated by RPS3 phosphorylation due to 
extracellular signal-regulated kinase (ERK1/2), cyclin-dependent kinase (CDK1), and protein kinase C- $\delta$ [114-117], whereas nuclear protein phosphatase 2A appears to counteract this process [118]. RPS3 possesses endonuclease activity [119-122] and interacts with the base excision enzymes 8-oxoguanine DNA glycosylase 1 (OGG1) and apurinic/apyrimidinic endonuclease (APE/Ref-1) [123], in addition to uracil-DNA glycosylase (UNG) in human cells [124]. Human RPS3 additionally interacts with transcription factor IIH (TFIIH) and is involved in the nucleotide excision repair pathway [125]. RPS3 has also been identified to participate in DNA repair and replication through stress-induced interaction with RecQ-like helicase 4 (RecQ14) in human cells [126].

In addition to participating in DNA repair and sustaining the genome integrity, RPS3 can induce apoptosis. RPS3 binds E2F1 and promotes proapoptotic gene induction in rat neurons. However, Akt-dependent phosphorylation of RPS3 disrupts this interaction, stimulating the nuclear accumulation of RPS3, and its repair function in the nucleus sustains neuronal survival [127]. The translocation of RPS3 to the nuclear membrane in murine lymphocytic cells has also been associated with the induction of apoptosis [128].

Other RPs are also involved in DNA damage pathways. In the nucleolus, human RPSA interacts with RNF8 protein, which is involved in the DNA damage response. DNA damage causes the release of RNF8 and BRCA1 to the nucleoplasm, which is regulated by RPSA [129]. Human RPL6 interacts with the histone H2A/H2AX and is recruited to DNA damage loci in a poly (ADP-ribose) polymerase (PARP)-dependent manner. RPL6 is important for the binding of mediator of DNA damage checkpoint protein 1 (MDC1) with $\gamma \mathrm{H} 2 \mathrm{AX}$ and the further recruitment of additional repair proteins. RPL8 and RPS14 are also recruited to DNA damage sites [130].

Human RPS27L binds to proteins FANCD2 and FANCI, which are components of the interstrand cross-link repair pathway. RPS27L binding prevents their degradation and stimulates DNA repair [131]. Interaction in human cells has been reported between RPLP0 and the DNA repair enzyme and transcriptional co-activator APE1/Ref-1, which serves as a master regulator of the cellular response to oxidative stress conditions [132]. Moreover, RPLP0 has been hypothesized to act as an endonuclease involved in DNA repair in Drosophila [133].

The DNA repair and telomere maintenance protein nibrin (NBS1) might be regulated by Mdm2; their interaction is affected by several Mdm2-binding RPs in human cells [134] (see below). A role of human RPL3 in the control of DNA repair activity has also been described [135]. Human eIF2 participates in the stabilization of the DNA-dependent protein kinase (DNA-PKcs)-Ku complex during DNA double-stranded break repair, and eIF2S2 is a substrate of DNA-PK [136].

eIF3e localizes to DNA damage loci and participates in repair processes via interactions with ATM protein kinase to promote the loading of the RAD51 recombinase in human cells $[137,138]$. The COP9 signalosome, which carries eIF3e as a subunit, plays a regulatory role in the DNA repair response [139].

Several CTAs contribute to the regulation of DNA replication. RPL5A and RPL5B participate in regulating the telomere length set point in Arabidopsis [140]. Human eIF3e also interacts with the polyubiquitinylated form of the replication factor MCM7 in the nucleus, which prevents its proteasomal degradation and increases its association with chromatin [141]. RPL4 is essential for replication of viral DNA, acting via interactions with Epstein-Barr virus nuclear antigen 1 (EBNA1), and the formation of the origin of plasmid replication (oriP) complex [142].

The eEF1ع1 subunit (AIMP3, aminoacyl tRNA synthetase complex component) is translocated to the nuclei of actively proliferating human cells during the S-phase. AIMP3 also localizes to the nucleus in response to DNA damage by UV exposure and adriamycin treatments. In response to DNA damage, this factor directly interacts with the ATM/ATR kinase, resulting in the subsequent activation of p53 [143]. The deletion of AIMP3 in mice causes the accumulation of DNA damage, indicating its involvement in the regulation of genome stability $[144,145]$. Another component of the tRNA synthetase complex, AIMP2, 
contributes to the DNA damage response by translocating to the nucleus, interacting with p53, and preventing its Mdm2-mediated degradation in murine cells [146]. Nuclear AIMP2 also promotes the degradation of the FBP, a transcriptional activator of c-Myc in human cells [147].

Nuclear eEF2 has the opposite genome-destabilizing effect. It is phosphorylated by C-terminal Src kinase (CSK), which is coupled with proteolytic cleavage. The nuclear translocation of the cleaved product causes genome instability, nuclear deformation, and aneuploidy formation in human cells [148].

\section{Roles of CTAs in Transcriptional Regulation}

RPs and rRNAs have been identified in active transcription sites. The recruitment of RPs to chromatin occurs co-transcriptionally in an RNA-dependent manner. RPS2, RPS5A, RPS9, RPS11, RPS13, RPS18, RPL8, RPL11, RPL32, and RPL36 have been found at active loci on polytene chromosomes in Drosophila, and RNase treatment substantially reduces their association with chromosomes. In addition, eIF5B and eRF3 have been found at active transcription sites on polytene chromosomes, colocalizing with RNA polymerase II (RNAP II) $[149,150]$.

The presence of RPL7, RPL11, and RPL25 (homolog of human RPL23A) at active transcription loci has been observed in S. pombe; RPs localize to protein-coding and nonprotein-coding genes, including tRNA, snoRNA, snRNA, and 5S rRNA genes. Moreover, these RPs are also localized on genomic repeats and centromeres. RP recruitment to chromosomes in yeast occurs predominantly in an RNA-dependent manner [151]. The association of RPS7, RPL7, RPL26, and RPL34 with nascent transcripts in yeast was shown in another study [152]. RPS14 inhibits the transcription of its own gene in human cells [153]. RPL12 is required for the transcription of phosphate signal transduction (PHO) pathway genes in yeast [154].

The presence of CTAs in condensed chromatin has also been described. Several RPs interact with histone H1 in Drosophila, and H1 and RPL22 reside in condensed chromatin. $\mathrm{RP}-\mathrm{H} 1$ interactions are likely important for transcriptional repression [155]. The analysis of the H1 interactome revealed multiple RPs, eIF3 subunits, and other CTAs [156,157]. The interactome for the heterochromatin protein HP1a in Drosophila includes eIF2S2, eIF3d1, eIF4A, eIF4B, eIF5A, eIF4G, eEF1A1, eEF2, and multiple RPs [158], and eIF4A interacts with HP1c in Drosophila [159]. The nuclei of human sperm containing condensed chromatin are also abundant in multiple RPs [160].

Multiple interactions of RPs with specific and general TFs have been described. RPs are commonly involved in transcriptional regulation through the modulation of transcription factors (TFs) function. Several RPs were co-purified with TFIIIE and recruited to tRNA and 5S rRNA genes in S. cerevisiae [161]. RPL11 represses c-Myc-dependent RNAP III transcription in mammalian cells [162], and RPS20 is involved in RNAP III transcription termination control in yeast [163]. In mammals, RPL11 binds to the c-Myc and represses the activity of its target promoters [164]. Human RPS14 also interacts with c-Myc and prevents the recruitment of c-Myc and its co-activator TRRAP to target genes [165]. Nuclear RPL3 binds to the phosphorylated TF Sp1, which is hypothesized to result in promoter-dependent effects, resulting in either the dissociation or stable recruitment of Sp1 in human cells [166].

Murine RPS3A binds the TF C/EBP homologous protein (CHOP, also known as GADD153) to inhibit its activity [167]. Human RPS3A also inhibits the activities of the transcriptional co-activator EBNA5 of the Epstein-Barr virus [168] and nuclear PARP [169]. Human RPS2 binds the putative TF zinc finger protein 277 (ZNF277) in human cells [170]. RPLP1 and RPLP2 show intrinsic potential to activate transcription in yeast [171].

Mammalian RPL13 stimulates the activity of $N F-\kappa B$ and IFN- $\beta$ promoters and is targeted by specific viral proteases due to its contributions to the antiviral response [172]. RPL10A in Arabidopsis relocates to the nucleus after phosphorylation by NIK1 kinase [173]. In the nucleus, RPL10A interacts with the transcription repressor L10-interacting MYB 
domain-containing protein (LIMYB), which downregulates the expression of RP genes as a component of the antiviral defense strategy in plants [174].

RPs can affect the recruitment of TFs to their target loci. RPL6 mediates the DNA binding of the TF Tax, expressed by HTLV-1 [175]. Human RPL7 counteracts the binding of vitamin D receptor retinoid $X$ receptor (VDR-RXR) with its target loci [176], whereas rat RPL11 counteracts the binding of peroxisome proliferator-activated receptor- $\alpha$ (PPAR- $\alpha$ ) [177]. RPL10 participates in the suppression of c-Jun homodimer binding with DNA in human cells [178].

In mammals, RPS3 is essential for nuclear factor (NF)- $\kappa B$ signaling by stabilizing the NF- $\kappa B$ binding with target genes [179]. Modification of the NF- $\kappa B$ p65 subunit promotes its binding with RPS3 [180], an interaction that is enhanced by the factor of immune response lipocalin 2 [181]. The nuclear localization of RPS3 requires phosphorylation by the inhibitor of NF- $\kappa B$ kinase $(\mathrm{IKK} \beta$ ) or casein kinase $2 \alpha$, and nuclear RPS3 promotes specific NF- $\mathrm{B}$ functions [182,183]. By contrast, the deubiquitination of human RPS3 blocks its nuclear translocation [184]. Human RPS3 also binds p53 to protect it from ubiquitination [185].

RPs are involved in the regulation of p53 transcriptional response. In mammals, multiple RPs bind to Mdm2, an E3 ligase and negative regulator of p53 [186-193]. The RP-Mdm2-p53 pathway connects ribosomal biogenesis with p53 activity [194]. Nucleolar stress causes the release of RPs to the nucleoplasm, which blocks Mdm2 and stimulates p53 activity. RPL11 and RPL5 are the principal players in this process [166,195]. Moreover, the formation of a complex between human RPL11 and Mdm2 is required for the recruitment of the p53 transcriptional coactivators p300/CBP to target promoters and the acetylation of p53 at K382. This process is accompanied by the neddylation of RPL11 [196]. This modification controls both nuclear and nucleolar localization of human RPL11, also contributing to the regulation of p53 activity $[197,198]$. Human RPL11 also directly interacts with the tumor suppressor ADP-ribosylation factor (ARF), forming a complex with Mdm2 and p53, which enhances p53 transcriptional activity [199]. The nucleolar protein GRWD1 mediates the opposite effect by binding RPL11 and blocking its interaction with Mdm2 in human cells [200]. Another nucleolar protein, spindling 1 (SPIN1), sequesters human RPL5 in the nucleolus, preventing its interaction with Mdm2 [201].

RPS26 interacts with p53 independently of Mdm2, forming a complex with p53 and p300, contributing to the p53 transcriptional response in mammals [202]. Genotoxic agents cause the proteasomal degradation of human RPL37 in the nucleoplasm and trigger the RPL11-dependent stabilization of p53 [203]. Similarly, silencing of human RPS9 activates p53 [204]. In addition, RPS2, RPS7, and RPS27A are substrates of Mdm2 in human cells, further contributing to the regulation of the p53 response [189,191,192,205].

RPs contribute to E2F1 functioning, as mentioned above for RPS3 [127]. RPL11 binding to Mdm2 stimulates E2F1 degradation and induces apoptosis in human cells [166,195]. RPL3 also negatively regulates the activity of E2F1-dependent promoters by interacting with PARP1 and sequestering it from promoters in human cancer cells [206].

Human RPL5 and RPL11 induce the transcriptional activity of TAp73, a p53 homolog. Upon ribosomal stress, the RPs bind the transactivation domain of TAp73 to block the binding of the Mdm2 negative regulator [207]. Human RPS7, an Mdm2 partner protein, interacts with the multifunctional GADD $45 \alpha$ nuclear protein, preventing its Mdm2-mediated degradation. The cytotoxic agent arsenite enhances the RPS7-Mdm2 interaction, preventing GADD $45 \alpha$ ubiquitination and degradation, inducing the activation of a GADD $45 \alpha$-dependent cell death pathway [208].

RPs also affect gene expression via epigenetic regulation. In Drosophila, the K3me3modified RPL12 interacts with the epigenetic cofactor Corto via the Corto chromodomain. Corto and RPL12 colocalize in active chromatin on polytene chromosomes and are jointly involved in the regulation of euchromatin gene transcription, particularly heat shock genes and RP genes [209]. In this case, RPL12 might function jointly with the transcription factors $\mathrm{Mad} / \mathrm{Med}$, which are effectors in the BMP signaling pathway [210]. Another RP, RPLP0, is thought to be involved in epigenetic regulation by modifying position-effect variegation in Drosophila [211]. 
RPS6 is recruited to promoters of rRNA genes and, together with histone deacetylase 2, silences rDNA transcription in plants [212]. Plant RPS6 also interacts with nucleosome assembly protein 1 (NAP1), which, on the contrary, promotes rDNA transcription [213].

Direct interactions of several CTAs with RNA polymerases were found. Interactions between the Rpb11c $\alpha$ minor isoform of the human RNAP II subunit with eIF3a, eIF3i, and eIF3m have been described [214]. The Rpb4/7 heterodimer shows physical and functional interactions with the eIF3j and eIF3c subunits in yeast, although this interaction was investigated in the context of translation rather than transcription [215]. The RNAP II interactome in human cells shows the presence of eIF2S1, eIF4A1, eIF4A2, eIF4G, eIF5B, eIF6, eEF1A1, and multiple RPs. Although an extract from mitotic cells was used in this study, RNAP II interactions with other cytoplasmic proteins were much weaker than those with CTAs [216]. In line with these data, eIF3m depletion has a strong effect on transcription compared with a limited effect on translation in mice [217].

Mammalian eIF31 (PAF67) is found in the nucleolus and acts as a cofactor for RNAP I, participating in the initiation of rRNA gene transcription [218,219]. Phosphorylated eIF2S1 $(\mathrm{eIF} 2 \alpha)$ is hypothesized to have direct effects on the transcriptional activities of the basal TF RRN3/TIF-IA and RNAP I transcription in human cells [220].

The direct participation of translation factors in transcriptional regulation has been described in multiple studies. The C-terminal domain of eIF3e increases the activity of Pap1 TF, a component of the oxidative stress response in yeast [221]. eIF3e also interacts with the transcriptional repressor Rfp, which colocalizes in PML-containing nuclear bodies in mammalian lymphocytes. Rfp drives the translocation of eIF3e to nuclear bodies [38].

eIF3f in the human cell nucleus regulates the expression of 34 genes (eIF3F gene cluster) via cooperation with signal transducer and activator of transcription 3 (STAT3) and other TFs [222]. In the nucleus, eIF3f interacts with and colocalizes with CDK11 in human cells, and phosphorylation by CDK11 is likely responsible for the nuclear localization of eIF3f $[223,224]$. eIF3h has also been suggested to play a role in transcription or epigenetic regulation and has been described as an enhancer of variegation in mice [225].

Nuclear eIF5A2 binds to the promoter of the HIF1 $\alpha$ gene, activating its transcription. An accumulation and nuclear translocation of eIF5A2 in human cells are induced by hypoxia. [226].

eEF1A displays nuclear localization in human fibroblasts [227]. eEF1A is involved in the heat shock response through the eEF1A1-mediated stimulation of heat shock factor 1 (HSF-1), which is recruited to the HSP70 gene promoter in human cells, resulting in HSP70 transcription. eEF1A1 also binds to the elongating RNAP II and the $3^{\prime}$ UTR of HSP70 mRNA, contributing to the stabilization and export of mRNA from the nuclei. By contrast, the paralogous factor eEF1A2 does not affect HSF-1 binding to the promoter [228]. The interaction between RNAP II and TAR RNA of HIV-1 is stabilized by eEF1A, which is important for transcriptional stimulation [229]. Nuclear eEF1A in Trypanosoma has been suggested to be involved in specific transcriptional programs [230].

eEF1A also interacts with the zinc finger-associated domain (ZAD) of the TFs Zw5, ZIPIC, and Grau in Drosophila, presumably regulating the transcriptional activity of their target genes [231]. eEF1A in human T lymphocytes forms a complex with the tyrosine kinase Txk and PARP1. eEF1A and PARP1 are phosphorylated and translocated into the nucleus upon cell stimulation. This complex is recruited to the IFN- $\gamma$ gene promoter and supports the transcriptional activity of IFN- $\gamma$ [232]. eEF1A also interacts with zinc finger protein ZPR1 in both mammalian cells and yeast. ZPR1 is a signaling factor that communicates proliferative growth signals from the cytoplasm to the nucleus. Upon stimulation, both proteins are translocated into the nucleus, which is an important process for cellular proliferation $[233,234]$. In the murine cell nucleus, eEF1A2 is a substrate of PKC $\beta I$ kinase, which is involved in various signaling pathways [235].

eEF1B has also been found in the nuclei of human cells. The interactome of nuclear eEF1B $\beta$ indicates a putative role in transcription, splicing, and DNA damage response, whereas the interactome of nuclear eEF1B $\gamma$ suggests a role in the splicing and 
control of mRNA stability [236]. Moreover, eEF1B $\gamma$ binds the Rpb3 subunit of RNAP II and is recruited to the promoters of genes encoding vimentin, Che1 (AATF), and p53 in human cells $[237,238]$. The nuclear localization of eEF1B $\gamma$ has also been described in Drosophila [239]. A specific long isoform, eEF1B $\delta \mathrm{L}$, is highly expressed in the human brain and testes. This isoform harbors an additional N-terminal sequence with an NLS, resulting in nuclear localization. This protein is a TF that cooperates with HSF-1 and Nrf2 TFs to support the transcription of heat shock element-carrying genes [240,241].

In addition to direct participation in transcription, CTAs regulate the subcellular/ subnuclear localization and cell levels of specific TFs, thus indirectly affecting transcriptional activity. RPL23 serves as a negative regulator of Myc-associated zinc finger protein (MIZ-1)-dependent transcription in human cells by retaining its essential coactivator nucleophosmin in the nucleolus [242]. Human RPS27 is required for NF- $\mathrm{kB}$ phosphorylation and nuclear translocation [243]. RPS27 also regulates NF- $\mathrm{KB}$ signaling in shrimp [244]. Human RPS3A stimulates NF- $\mathrm{KB}$ nuclear translocation synergistically with hepatitis B virus X protein ( $\mathrm{HBx}$ ) [245]. RPL41 induces the phosphorylation and relocalization of the activating transcription factor 4 (ATF4) from the nucleus to the cytoplasm, resulting in its subsequent proteasomal degradation in human cancer cells [246]. Stress conditions induce eIF2S1 (eIF2 $\alpha$ ) phosphorylation, resulting in the general inhibition of translation. However, simultaneous activation of specific translation of the ATF4 mRNA was described in mammalian cells. Increased levels of ATF4 induce a specific transcription program that allows the cell to respond to stress [247]. eEF1A participates in the phosphorylation and nuclear localization of the STAT3 TF upon Helicobacter infection in mammals [248]. eIF3e interacts with and directs the proteasomal degradation of HIF- $2 \alpha$ in mammals $[45,249]$. Human eIF3f is a deubiquitinase that deubiquitinates the Notch1 receptor, allowing for its TF activity [250]. eIF3h deubiquitinases YAP and Snail TFs, which stabilizes these proteins and promotes the corresponding signaling in human cells [251,252].

eEF1A is a component of the nuclear protein export pathway in mammalian cells. Cargo proteins harboring specific transcription-dependent nuclear export motifs couple export with RNAP II transcription [253]. The signal for eEF1A-dependent export is a polyalanine tract, the disruption of which can result in the mislocalization of several TFs and disease development [254]. Acetylated eEF1A1 is translocated to the nucleus in mammalian nervous system cells, where it binds the TF Sox10 and promotes its export [255]. Human eEF1A is also involved in the nuclear export of the Snail TF through the Exp5Aminoacyl-tRNA complex [256]. Mammalian eEF1A is exported from the nucleus via interaction with exportin-5, which is tRNA-dependent $[27,257]$. In yeast, eEF1A is also required for the re-export of aminoacylated tRNAs to the cytoplasm [258].

Human tyrosyl-tRNA synthetase (TyrRS) regulates gene expression by an epigenetic mechanism. Stress conditions cause the nuclear localization of TyrRS. The binding of nuclear TyrRS to TRIM28/histone deacetylase 1 (HDAC1) repressor complex blocks its activity toward E2F1 and stimulates the transcription of E2F1-dependent genes [259]. TyrRS also binds 20 genes encoding translation machinery components, recruits the TRIM28/HDAC1 or nucleosome remodeling deacetylase (NuRD) complex, and represses the transcription of these loci [260]. The nuclear translocation of TyrRS is regulated by acetylation, which is under control of p300/CBP-associated factor (PCAF) and sirtuin 1 enzymes [261]. Some mutations in TyrRS have been associated with E2F1 hyperactivation and the development of Charcot-Marie-Tooth neuropathy [262].

Cytoplasmic polyA-binding protein (PABPC) is a multifunctional RNA-binding protein that regulates various aspects of protein translation and mRNA stability. Several paralogous PABPCs have been described in mammals and plants; studies in mammals usually focus on PABPC1 as a predominant one in the cell. Nuclear translocation of PABPC is specifically induced by infection with viruses of various classes or occurs in response to cell stress in mammals and plants [263-275]. Virus-induced nuclear translocation of PABPC causes the general inhibition of translation [276] while allowing for viral protein synthesis to continue [277]. Viral protein synthesis could be realized via viral nuclear non-coding 
RNAs, which bind nuclear PABPC and selectively targets viral RNA for export and expression [278]. The nuclear accumulation of PABPC causes mRNA hyperadenylation and blocks its export, downregulating gene expression in mammalian cells [279]. In addition to the general translation shutoff, the nuclear localization of PABPC could result in the reprogramming of translation for specific subsets of mRNAs and affect mRNA stability and splicing $[270,280]$.

The inhibition of transcription results in PABPC1 accumulation in nuclear speckles in human cells where it colocalizes with the splicing component SC35, and the nuclear localization of PABPC1 requires ATP [281]. In mammals, PABPC1 in the nucleus binds to polyadenylated intron-containing pre-mRNA [282]. An interaction between human PABPC1 and histone H1 was also described [157], and in virus-infected cells, fish PABPC is associated with both histones and splicing factors [276].

PABPC nuclear import depends on an interaction with $\alpha$-importins, whereas the nuclear export of PABPC depends on ongoing mRNA export and occurs in an mRNAdependent manner in mammals $[280,283]$. Export of mammalian PABPC1 occurs in a transcription-dependent manner with the participation of eEF1A [253]. Human PABPC1 participates in the nuclear trafficking of long interspersed element-1 (LINE1) ribonuclear protein (RNP), which is essential for L1 retrotransposition [284]. The NLS of PABPC resides in an RNA-binding domain and is masked by interactions with RNA. Thus, mRNA degradation or cytoplasmic deadenylation exposes the NLS, allowing for interactions with importins and driving the nuclear relocalization of PABPC [285,286].

The nuclear translocation of human PABPC impairs the recruitment of RNAP II and TATA-binding protein to promoters during the early stages of transcription but has no effects on the phosphorylation of the RNAP II C-terminal domain (CTD) or the recruitment of RNAP III. Thus, PABPC serves as an indicator of mRNA abundance, as the degradation of cytoplasmic mRNA results in its translocation to the nucleus and the inhibition of transcription [287]. As a result, PABPC has opposing effects on mRNA depending on its localization, stabilizes mRNA in the cytoplasm, and represses its synthesis in the nucleus. This mechanism represents an important feedback pathway that connects nuclear transcription with the cytoplasmic fate of mRNA [288,289].

Other proteins are also involved in the regulation of PABPC localization. The RNA helicase DEAD-box helicase 3 X-linked (DDX3X) interacts with PABPC1, and the downregulation of DDX3X causes the nuclear accumulation of PABPC1 in human cells [290,291]. A similar effect was observed for the cytoskeletal protein paxillin, which interacts with human PABPC1 in the nucleus, and both proteins are exported via the CRM1-exportin pathway [292].

PABPC1 binds the androgen receptor (AR) and is required for both AR-dependent transcription and its nuclear localization in human prostate cells [293]. Interestingly, paxillin is also a coregulator of AR, which is induced by androgens and EGF signaling [294]. PABPC stimulates the nuclear import of the TF Mld, but not other TFs during the ecdysone response in Drosophila [295].

For the single polyA-binding protein (PAB1) in S. cerevisiae, the nuclear import receptor Kap108/Sxm1 is known to be involved in the shuttling of PAB1 between the nucleus and the cytoplasm. Interestingly, the disruption of PAB1 import into the nucleus also affects mRNA export from the nucleus [296]. PAB1 is associated with cleavage factor IA (CFIA) and participates in the formation of the $3^{\prime}$-end of mRNA [297].

Participation in transcription has been described for Drosophila PABPC-interacting protein 2 (Paip2), which is a translational inhibitor [298]. Paip2 was also found in the nucleus, where it binds active promoters in an RNA-dependent manner [299]. Paip2 is associated with various proteins, including the mRNA capping protein CBP80. Paip2 and CBP80 regulate the level of serine-5 CTD RNAP II phosphorylation on the promoter [300] and participate in the mRNA capping checkpoint [301]. 


\section{Role of CTAs in mRNA Processing}

Nuclear CTAs have been associated with mRNA splicing and $5^{\prime}$ - and $3^{\prime}$-processing. RPs affect the transcription, splicing, and translation stages of their own gene expression [302-304]. In mammals, RPS13 represses its own expression by binding its pre-mRNA and disrupting spliceosome assembly to inhibit splicing [305]. The self-suppression of premRNA splicing was also shown for RPS9 [306], RPS14 [307,308], RPS26 [309], RPL3 [310], RPL4 [311], RPL10A [312], RPL12 [313], RPL22 [314], RPL30 [315,316], and RPL32 [317,318] in various organisms. Regulation of RP gene expression via splicing is of special importance in budding yeasts, in which RP genes belong to a small group of intron-containing genes $[306,319,320]$.

Human RPL3 is associated with alternative splicing by recruiting several factors to its own pre-mRNA to promote the selection of an alternative splice site, forming an mRNA with a premature stop codon that is degraded by the NMD pathway [310,321,322]. The pre-mRNA splicing of other genes is also regulated by these proteins. RPL22 and its paralog RPL2211 have opposing effects on splicing in Danio rerio during gastrulation. RPL22 binds introns and induces exon 9 skipping in smad2 pre-mRNA, whereas RPL22l1 promotes exon 9 inclusion [323]. Two RPL22 paralogs in yeast negatively affect the splicing of each other's pre-mRNAs [324]. RPL26 participates in $p 53$ pre-mRNA splicing and the generation of specific mRNA isoforms in human cancer cells [325].

Human RPS3A interacts with the U5 and U11 snRNAs, which are required for U11 snRNA processing and minor-class splicing [326]. In Arabidopsis, RPL24 binds pre-miRNA and facilitates its processing [327].

Human eIF4E colocalizes with splicing factors (U1 snRNP) in cell nuclei and concentrates in nuclear speckles in an RNA-independent manner. Speckles appear to serve as functional sites for the formation of certain RNPs. Treatment of cells with the DRB (an inhibitor of RNAP II activity) causes the condensation of eIF4E granules, whereas overexpression of the Clk/Sty kinase causes dispersion of nuclear speckles [328]. eIF4E contributes to the female-specific alternative splicing of $m s l-2$ and $S x l$ pre-mRNAs in Drosophila. eIF4E has been associated with several splicing factors in flies [329].

Human eIF4E interacts with factors involved in mRNA $3^{\prime}$ processing in the nucleus, stimulating the maturation of several transcripts in human cells, which occurs independently of its participation in mRNA export [330]. Human eIF4E also stimulates the capping of hundreds of coding and non-coding RNAs harboring a specific signal [331].

In human cells eIF2A, eIF4A, eIF4G1, eIF3a, eIF3b1, eIF3e, eIF3f, eIF3h, eIF3i1, eEF1A, and eEF1B $\gamma$ are associated with the pre-mRNA $3^{\prime}$ processing complex [332]. The yeast homolog of eEF1A, the Tef1 protein, interacts with the CFI pre-mRNA processing factor $[333,334]$.

Human eIF3e co-purifies with nuclear mRNA cap-binding protein CBP80 [335].

Human eIF4A1 is also associated with the nuclear CBP80, and this interaction is further stimulated by the viral protein Rev during HIV-1 infection [71]. In Drosophila, nuclear eIF4A was also described [336], and its association with splicing regulators was shown [337]. The paralogous factor eIF4A3 is not involved in translation but serves as a component of the spliceosome and the exon junction complex (EJC) [338] and participates in ribosome biogenesis [339]. Interestingly, subcellular localization of eIF4A3 is also regulated [340,341].

A significant pool of the translation initiation factor eIF4G is localized in the nuclei of mammalian cells, where it interacts with the cap-binding complex $(\mathrm{CBC})$ but not with nuclear eIF4E. eIF4G also interacts with spliceosomal snRNPs and splicing factors. eIF4G is recruited to pre-mRNA via the $C B C$, and this complex is exported to the cytoplasm [342]. In yeast, eIF4G is also associated with spliceosome components, and its depletion downregulates splicing [343].

eIF4G3 (but not the eIF4G1 paralog) localizes to the nuclei of mammalian spermatocytes in the region of a specific $\mathrm{XY}$ body. Mutations in the eIF4G3 gene cause meiosis arrest and male infertility. eIF4A1, eIF4E, eIF4E2, RPS6, RPL10L, and other CTAs are also localized in the XY body, where they are likely associated with mRNA metabolism [344]. 
Cytoplasmic polyadenylation element-binding (CPEB) proteins promote polyadenylationinduced translation in the cytoplasm $[345,346]$, and all CPEB proteins act as shuttling proteins. The blockade of CRM-1-dependent nuclear export causes the nuclear accumulation of CPEB1, CPEB3, and CPEB4 in human cells. Stimulated neurons also show increased CPEB accumulation in the nucleus. In particular, the nuclear accumulation of CPEB4 depends on the depletion of calcium from the ER [347]. Nuclear CPEB1 in human cells was found in a few foci associated with the nucleoli, which contain CRM1 and might play a role in ribosome biogenesis [348]. In Xenopus oocytes, CPEB is associated with lampbrush chromosomes and several factors involved in nuclear RNA processing. In mouse fibroblasts, CPEB mediates alternative splicing [349]. In HeLa cells, CPEB1 colocalizes with splicing factors in the nucleus. CPEB1 binds with pre-mRNA, mediates the selection of alternative sites of polyadenylation, and shortens the $3^{\prime} \mathrm{UTR}$ of different transcripts. CPEB1 also affects alternative splicing by preventing the recruitment of the splicing factor U2AF65 [350]. During neurogenesis, murine CPEB3 serves as a crucial regulator of alternative splicing [351]. Nuclear CPEB3 interacts with STAT5b and inhibits transcriptional activity in mouse neurons. The NMDA-mediated activation of neurons stimulates the nuclear accumulation of CPEB3 in an IPO5-dependent manner, further downregulating the expression of the STAT5b target gene EGFR [352,353].

\section{Role of CTAs in Nuclear mRNA Export}

As indicated above, eIF4E is involved in nuclear mRNA biogenesis. Moreover, it defines a specific mRNA export pathway. In the nucleus, human eIF4E is specifically associated with the mRNA encoding the CDK1 and is involved in its export. The eIF4Esensitive element (4E-SE) binding site for eIF4E in CDK1 mRNA is approximately $100 \mathrm{nt}$ found in the $3^{\prime} \mathrm{UTR}$ [354]. In human cells, the overexpression of eIF4E alters the composition of the nuclear pore complex (NPC), increasing the export of Gle1, DDX19, and RanBP1 mRNA [355].

The eIF4E-dependent export pathway for RNPs differs from the general RNP export pathways [TAP/NXF1 or REF/Aly] and requires the participation of the CRM1-exportin system. Currently, approximately 3000 transcripts in human cells are known to be eIF4E export targets, many of which encode oncoproteins [356-358].

eIF4E-dependent mRNA export is affected by other proteins. Human eIF4E interacts with PML, which reduces the affinity of eIF4E for the mRNA cap [359]. PML can cause the retention of cyclin D1 mRNA in the nucleus, while eIF4E inhibits this retention and alters the morphology of PML bodies in human cells [39]. The human homeodomain protein HOXA9 stimulates the eIF4E-dependent export of mRNAs encoding cyclin D1 and ornithine decarboxylase (ODC) from nuclei, increasing the efficiency of ODC synthesis. This function of HOXA9 is transcriptionally independent and occurs via competition with another homeodomain protein PRH, which represses the eIF4E function [360]. Several candidate cofactors for the human eIF4E have been identified, which are associated with mRNA export [357,358]. One of these eIF4E partners is the LRPPRC protein, which binds both eIF4E and the 4E-SE element in mRNA. The overexpression of LRPPRC affects the nuclear export of several eIF4E-dependent mRNAs.

eIF5A is another factor that contributes to mRNA export control. eIF5A1 is associated with the intranuclear filaments of the NPC in mammalian cells and Xenopus oocytes. eIF5A1 acts as a shuttling protein, which interacts with the CRM1 nuclear receptor. In particular, eIF5A1 is essential for HIV-1 Rev RNA transport [361]. Moreover, nuclear eIF5A1 is important for HIV-1 Rev protein functions in transcriptional activation and viral RNA export [362-364]. eIF5A is additionally acts as a cofactor of HTLV-I Rex RNA export factor [365].

The role of the eIF5A-dependent export pathway was shown for several other transcripts. In mammalian cells, Sirtuin-1 (Sirt1) serves as a pH-sensor that deacetylates nuclear eIF5A during anaerobiosis, directing the export of eIF5A with associated TSC2 mRNA. TSC2 induces metabolic depression [366]. Hypusinated eIF5A transports a set of specific 
mRNAs from the nucleus to ribosomes for translation, which is a mechanism employed by murine macrophages due to the induction of hypusinating deoxyhypusine synthase (DHPS) enzyme by bacterial infections [367]. Hypusination of eIF5A is crucial for the export of the Nos 2 mRNA upon the cytokine response of islet $\beta$ cells in mice [368]. Hypusine modification of eIF5A is essential for CD83 mRNA export and the full stimulatory activity of mature human dendritic cells [369].

The negative regulator of translation PDCD4, which controls eIF4A function during translation, resides predominantly in the nucleus under normal growth conditions in murine cells. Under serum starvation conditions, PDCD4 accumulates in the cytoplasm, although the inhibition of CRM1-dependent nuclear export prevents this accumulation. PDCD4 binds RNA and may be involved in nuclear RNA metabolism [370]. During metastasis in several cancers, a shift can be observed from a nuclear to cytoplasmic localization for PDCD4 [371].

\section{Nuclear Localization of some CTAs Is Associated with Oncogenesis}

The nuclear and subnuclear localization of several CTAs is associated with the development of an oncogenic phenotype. The RP-Mdm2-p53 pathway, described above, is important for tumor surveillance [194]. RPL11 retention in the nucleolus is important for tumor progression. The tumor suppressor PICT1 interacts with RPL11 and other RPs to maintain their nucleolar localization. Under stress conditions, PICT1 becomes depleted, and RPL11 escapes into the nucleoplasm, where it binds Mdm2 and blocks p53 ubiquitination $[166,372,373]$. The relocalization of RPL11 to the nucleoplasm can be detected under oncogenic or replicative stress conditions, and other components of the 5S RNP complex (RPL5 and 5S rRNA) are also involved in p53 activation [374].

The formation of an alternative Mdm2-RPL5 complex with the splicing factor SRSF1 also contributes to p53 stabilization and has been described in cells under stress conditions [375]. RPL26 regulates $p 53$ pre-mRNA splicing. Ionizing irradiation or methyl methanesulfonate treatment induces the binding of RPL26 to $p 53$ pre-mRNA, further inducing the recruitment of the splicing factor SRSF7 and the generation of alternatively spliced $p 53 \beta$ mRNA, which can induce a cellular senescent phenotype [325]. In several types of cancer, RPS3 as a component of the NF- $\mathrm{BB}$ TF contributes to the upregulation of prosurvival genes, radioresistance, and cancer development [134].

Specific RNA giant nuclear body has been observed in cancer cells but not normal cells. eIF3d, eIF4A1, eIF4E, eEF1B $\delta$, eEF2, and 47 RPs contribute to the composition of the body [376]. Nuclear accumulation of eIF2S1 (eIF2 $\alpha$ ) in gastrointestinal carcinomas cells [377] and meningioma cells [378] has also been described.

The regulation of eIF3e nuclear localization could be a mechanism for tumorigenesis, as shown in fibroblasts [45,379]. eIF3f is localized in the nuclei of adenocarcinoma cells and regulates the expression of genes that control key events accompanying tumor formation. In particular, eIF3f regulates the expression of the central effector of metastases, Snail2, which is important for the induction of the epithelial-mesenchymal transition [222].

eIF4E is a pro-oncogenic protein that is highly upregulated in many cancers [380]. The abundance of nuclear phosphorylated eIF4E, such as in oligodendroglial tumors [378], is associated with increased tumor burden and reduced response to chemotherapy [381]. The overexpression of RAN binding protein 2 (RANBP2) specifically inhibits the eIF4E mRNA export pathway and impairs eIF4E-dependent oncogenic transformation. eIF4E overcomes these inhibitory mechanisms by indirectly lowering RANBP2 levels. Thus, the reprogramming of mRNA export allows this oncogene to control cell proliferation [355], as also demonstrated in acute myeloid leukemia (AML). The nuclear accumulation of eIF4E in AML patients correlates with an increase in the eIF4E-dependent export of oncoproteinencoding transcripts. Importin-8 is involved in the direct import of eIF4E into the nuclei. Patients with AML have high levels of importin-8, leading to the increased accumulation of eIF4E in the nucleus. Thus, the importin-8-eIF4E complex is regarded as a new target for cancer therapy [382]. The phosphorylation of nuclear eIF4E is crucial for the proper control 
of mRNA export and oncogenic activity. Mitogen-activated protein kinase interacting kinases (MNKs) control the phosphorylation of eIF4E, and some other signaling pathways are also involved in the control of eIF4E activity [383].

eIF5A1 accumulates at high levels in the cytoplasm and nuclei of lung tumor cells, A549 cells, and lymphocytic cells $[64,384,385]$. eIF5A1 expression is also altered in esophageal cancer. eIF5A1 is rapidly translocated to the nucleus by tumor necrosis factor $\alpha$ (TNF$\alpha$ ), death receptor activation, or treatment with actinomycin $\mathrm{D}$ in colon adenocarcinoma cells. Unhypusinated eIF5A1, which is capable of nuclear localization, has pro-apoptotic functions in the nuclear form [386].

eIF5A may participate in oncogenesis by altering nucleocytoplasmic transport [387]. High levels of eIF5A2 in the nucleus and cytoplasm lead to low survival rates among patients with melanoma. eIF5A2 is a downstream target of the PI3K/Akt pathway and may induce the epithelial-mesenchymal transition [388,389]. The increased expression of eIF5A2 is associated with metastasis, angiogenesis, and shorter survival times in patients with esophageal squamous cell carcinoma. eIF5A2 may also act via the HIF1 $\alpha$-mediated signaling pathway [226].

eEF1A is required for the growth of tumor cells. Various eEF1A isoforms can be found in the nuclear fractions of T-lymphoblast cancer cells. eEF1A is the main nuclear protein that specifically recognizes aptameric cytotoxic oligonucleotides in these cells. By contrast, nuclear eEF1A in normal human lymphocytes does not show such activity [390]. The oncogene PTI-1 encodes a truncated version of eEF1A, which localizes to the nucleus [391]. The nuclear localization and interaction of eEF1A and eEF1B subunits appear to contribute to cancer development in some cases [392]. The nuclear CSK-dependent localization of eEF2 is associated with aneuploidy formation, which is directly linked to malignant transformation [148].

\section{Nuclear Translation Hypothesis}

The nuclear localization of multiple CTAs has served as the basis for the nuclear translation hypothesis. The first papers describing nuclear translation were published in the middle of the 20th century $[393,394]$ but were not subjected to criticism at that time, as the classical paradigm of separation between transcription and translation was just emerging. In the early 2000s, a hypothesis regarding nuclear translation was proposed [395], which was met with substantial criticism [396,397].

In pioneering work [395], permeabilized HeLa cells and extracted mammalian nuclei were incubated with labeled leucine and lysine-tRNAs. After incubation, newly synthesized polypeptides were found to be associated with discrete transcription factors. The hypothesis of "proofreading" for newly synthesized transcripts at the transcription loci was proposed. This model also suggests that NMD could occur directly in the nucleus [398].

New arguments for nuclear translation continue to be introduced. The formation of mature 80S ribosomes in the nucleoplasm was described [399], and the direct visualization of nuclear translation was performed [400]. An intriguing mechanism for the synthesis of peptides presented on major histocompatibility complex (MHC) class I molecules in T cells was suggested. Peptides might be synthesized on a pre-mRNA or intron template prior to mRNA splicing during the pioneer round of translation [401,402]. Moreover, these peptides can serve as tumor-associated antigens [403]. In general, nuclear translation is expected to generate multiple, short-lived peptides [404], implying an additional important functional output for nuclear translation, which can be implemented during cancer treatment $[405,406]$.

Noncanonical nuclear translation is thought to occur without the participation of a complete set of factors required for the cytoplasmic synthesis of full-length proteins [402]. Solid-like amyloid bodies could coordinate local nuclear protein synthesis by concentrating RPs and CTAs in the nucleus during stress [407]. Despite the use of a substantially wide range of methods to confirm the existence of nuclear translation, this model remains poorly accepted by the wider scientific community [408]. 


\section{Conclusions}

Multiple cytoplasmic factors, referred to as CTAs, have been found in the nuclei of various cell types, where they demonstrate a wide variety of functions. An overview of the principal findings in this field is provided in Table 1 and Figure 1. The data collected to date indicate that most CTAs commonly demonstrate a dual nuclear and cytoplasmic localization; however, different sets of CTAs present with nuclear localization in different cells and under different conditions.

Table 1. Overview of the nuclear localization and functions of core components of the translation apparatus (CTAs).

\begin{tabular}{|c|c|c|c|}
\hline $\begin{array}{c}\text { Protein (RP Names are Indicated } \\
\text { According to [3]) }\end{array}$ & $\begin{array}{c}\text { Nuclear Functions } \\
\text { (Pooled Data for All Species) }\end{array}$ & $\begin{array}{l}\text { Species in which Nuclear } \\
\text { Localization Was Detected }\end{array}$ & References \\
\hline RPSA & $\begin{array}{l}\text { Controls RNF8 and BRCA1 trafficking } \\
\text { Localized at active loci on chromosomes } \\
\text { Chromatin-associated } \\
\text { Found in the insoluble nuclear fraction }\end{array}$ & Mammals, flies, and plants & {$[25,26,33,42,129,149,150]$} \\
\hline RPS2 & $\begin{array}{c}\text { Binds Mdm2 and ZNF277 } \\
\text { Localized at active loci on chromosomes } \\
\text { Associated with HP1a } \\
\text { Associated with RNAP II } \\
\text { Associated with histone H1 } \\
\text { Chromatin-associated } \\
\text { Component of interchromatin granule clusters } \\
\text { Found in the insoluble nuclear fraction } \\
\text { Found in nuclei of sperm }\end{array}$ & Mammals and flies & $\begin{array}{c}{[33,40,42,149,150,157,158,} \\
160,170,188,189,216]\end{array}$ \\
\hline RPS3 & $\begin{array}{c}\text { Component of DNA damage response pathway } \\
\text { Endonuclease activity } \\
\text { Interacts with OGG1, APE/Ref-1, UNG, TFIIH, } \\
\text { and RECQL4 repair proteins } \\
\text { Induction of proapoptotic genes } \\
\text { Essential subunit of NF- } \mathrm{KB} \\
\text { Binds Mdm2, p53, E2F1, and ERH } \\
\text { Associated with HP1a } \\
\text { Associated with RNAP II } \\
\text { Chromatin-associated } \\
\text { Found in the insoluble nuclear fraction }\end{array}$ & Mammals, flies, and plants & $\begin{array}{c}{[25,26,33,42,54,96,108,114-} \\
128,134,158,179,181- \\
186,216,294]\end{array}$ \\
\hline RPS3A & $\begin{array}{c}\text { Binds CHOP, EBNA5, and PARP } \\
\text { Interacts with the U5 and U11 snRNAs } \\
\text { Binds phosphatidylinositol trisphosphate } \\
\text { Associated with HP1a } \\
\text { Associated with RNAP II } \\
\text { Associated with histone H1 } \\
\text { Chromatin-associated } \\
\text { Component of interchromatin granule clusters } \\
\text { Found in the chromosome scaffold fraction } \\
\text { Found in the insoluble nuclear fraction } \\
\text { Found in nuclei of sperm }\end{array}$ & Mammals, flies, and plants & $\begin{array}{c}{[25,26,33,40-} \\
42,107,157,158,160,167- \\
169,216,326]\end{array}$ \\
\hline RPS4 & $\begin{array}{c}\text { Localized at active loci on chromosomes } \\
\text { Associated with TFIIIE } \\
\text { Associated with HP1a } \\
\text { Associated with RNAP II } \\
\text { Chromatin-associated } \\
\text { Component of interchromatin granule clusters } \\
\text { Found in the chromosome scaffold fraction } \\
\text { Found in the insoluble nuclear fraction }\end{array}$ & Mammals, flies, yeasts, and plants & $\begin{array}{c}{[25,26,33,40-} \\
42,149,150,158,161,216]\end{array}$ \\
\hline RPS5 & $\begin{array}{c}\text { Localized at active loci on chromosomes } \\
\text { Associated with TFIIIE } \\
\text { Associated with HP1a } \\
\text { Associated with RNAP II } \\
\text { Chromatin-associated } \\
\text { Component of interchromatin granule clusters } \\
\text { Found in the insoluble nuclear fraction }\end{array}$ & Mammals, flies, yeasts, and plants & $\begin{array}{c}{[25,26,33,40,42,149,150,158,} \\
161,216]\end{array}$ \\
\hline
\end{tabular}


Table 1. Cont.

\begin{tabular}{|c|c|c|c|}
\hline $\begin{array}{c}\text { Protein (RP Names are Indicated } \\
\text { According to [3]) }\end{array}$ & $\begin{array}{c}\text { Nuclear Functions } \\
\text { (Pooled Data for All Species) }\end{array}$ & $\begin{array}{l}\text { Species in which Nuclear } \\
\text { Localization Was Detected }\end{array}$ & References \\
\hline RPS6 & $\begin{array}{c}\text { Binds and downregulates promoters of } \\
\text { rRNA genes } \\
\text { Interacts with NAP1 } \\
\text { Interacts with LANA } \\
\text { Associated with HP1a } \\
\text { Associated with RNAP II } \\
\text { Chromatin-associated } \\
\text { Component of interchromatin granule clusters } \\
\text { Found in the chromosome scaffold fraction } \\
\text { Found in the insoluble nuclear fraction } \\
\text { Found in nuclei of sperm }\end{array}$ & Mammals and plants & $\begin{array}{c}{[25,26,33,40-} \\
42,111,158,160,212,213,216]\end{array}$ \\
\hline RPS7 & $\begin{array}{c}\text { Binds Mdm2, GADD } 45 \alpha \text {, and BCCIP } \beta \\
\text { Associated with nascent mRNA } \\
\text { Chromatin-associated } \\
\text { Component of interchromatin granule clusters } \\
\text { Found in the insoluble nuclear fraction } \\
\text { Found in nuclei of sperm }\end{array}$ & Mammals, yeasts, and plants & $\begin{array}{c}{[25,26,33,40,42,105,152,160} \\
186,191,208]\end{array}$ \\
\hline RPS7A & Unknown & Plants & [26] \\
\hline RPS8 & $\begin{array}{c}\text { Localized at active loci on chromosomes } \\
\text { Associated with TFIIIE } \\
\text { Associated with HP1a } \\
\text { Associated with RNAP II } \\
\text { Associated with histone H1 } \\
\text { Chromatin-associated } \\
\text { Component of interchromatin granule clusters } \\
\text { Found in the insoluble nuclear fraction } \\
\text { Found in the chromosome scaffold fraction }\end{array}$ & Mammals, flies, yeasts, and plants & $\begin{array}{c}{[25,26,33,40-} \\
42,149,150,157,158,161,216]\end{array}$ \\
\hline RPS9 & $\begin{array}{c}\text { Localized at active loci on chromosomes } \\
\text { Suppression of splicing of its own pre-mRNA } \\
\text { Interacts with nucleophosmin } \\
\text { Associated with TFIIIE } \\
\text { Associated with HP1a } \\
\text { Associated with RNAP II } \\
\text { Associated with histone H1 } \\
\text { Chromatin-associated } \\
\text { Component of interchromatin granule clusters } \\
\text { Found in the insoluble nuclear fraction } \\
\text { Found in nuclei of sperm }\end{array}$ & Mammals, flies, and yeasts & $\begin{array}{c}{[33,40,42,103,104,149,150} \\
157,158,160,161,204,216 \\
306]\end{array}$ \\
\hline RPS10 & $\begin{array}{l}\text { Associated with HP1a } \\
\text { Chromatin-associated } \\
\text { Component of interchromatin granule clusters } \\
\text { Found in the chromosome scaffold fraction } \\
\text { Found in the insoluble nuclear fraction }\end{array}$ & Mammals, flies, and plants & {$[25,26,33,40-42,95,158]$} \\
\hline RPS11 & $\begin{array}{c}\text { Localized at active loci on chromosomes } \\
\text { Associated with HP1a } \\
\text { Associated with RNAP II } \\
\text { Chromatin-associated }\end{array}$ & Mammals, flies, and plants & {$[25,26,33,149,150,158,216]$} \\
\hline RPS12 & $\begin{array}{c}\text { Localized at active loci on chromosomes } \\
\text { Associated with RNAP II } \\
\text { Chromatin-associated }\end{array}$ & Mammals, flies, and plants & {$[25,26,33,149,150,216]$} \\
\hline RPS13 & $\begin{array}{c}\text { Suppression of splicing of its own pre-mRNA } \\
\text { Localized at active loci on chromosomes } \\
\text { Associated with HP1a } \\
\text { Associated with RNAP II } \\
\text { Associated with histone H1 } \\
\text { Chromatin-associated } \\
\text { Found in the insoluble nuclear fraction }\end{array}$ & Mammals, flies, and plants & $\begin{array}{c}{[25,26,33,42,149,150,157} \\
158,216,305]\end{array}$ \\
\hline RPS14 & $\begin{array}{c}\text { Recruited to DNA damage sites } \\
\text { Binds Mdm2 and c-myc } \\
\text { Localized at active loci on chromosomes } \\
\text { Inhibits transcription of its own gene } \\
\text { Suppression of splicing of its own pre-mRNA } \\
\text { Associated with HP1a } \\
\text { Associated with RNAP II } \\
\text { Chromatin-associated } \\
\text { Component of interchromatin granule clusters } \\
\text { Found in the insoluble nuclear fraction }\end{array}$ & Mammals, flies, and yeasts & $\begin{array}{c}{[33,40,42,130,149,150,153,} \\
158,165,186,216,307,308]\end{array}$ \\
\hline RPS15 & $\begin{array}{c}\text { Binds Mdm2 } \\
\text { Localized at active loci on chromosomes } \\
\text { Associated with HP1a } \\
\text { Associated with RNAP II } \\
\text { Associated with histone H1 } \\
\text { Chromatin-associated } \\
\text { Found in the insoluble nuclear fraction }\end{array}$ & Mammals, flies, and plants & $\begin{array}{c}{[25,26,33,42,149,150,157} \\
158,186,216]\end{array}$ \\
\hline
\end{tabular}


Table 1. Cont.

\begin{tabular}{|c|c|c|c|}
\hline $\begin{array}{c}\text { Protein (RP Names are Indicated } \\
\text { According to [3]) }\end{array}$ & $\begin{array}{l}\text { Nuclear Functions } \\
\text { (Pooled Data for All Species) }\end{array}$ & $\begin{array}{l}\text { Species in which Nuclear } \\
\text { Localization Was Detected }\end{array}$ & References \\
\hline RPS15A & Associated with RNAP II & Humans and plants & {$[25,26,216]$} \\
\hline RPS16 & $\begin{array}{c}\text { Associated with HP1a } \\
\text { Associated with RNAP II } \\
\text { Component of interchromatin granule clusters } \\
\text { Found in the insoluble nuclear fraction }\end{array}$ & Mammals, flies, and plants & {$[26,40,42,158,216]$} \\
\hline RPS17 & $\begin{array}{l}\text { Associated with HP1a } \\
\text { Found in the insoluble nuclear fraction }\end{array}$ & Humans, flies, and plants & {$[25,26,42,158]$} \\
\hline RPS18 & $\begin{array}{c}\text { Localized at active loci on chromosomes } \\
\text { Associated with HP1a } \\
\text { Associated with RNAP II } \\
\text { Chromatin-associated } \\
\text { Found in the insoluble nuclear fraction }\end{array}$ & Mammals, flies, and plants & {$[26,33,42,149,150,158,216]$} \\
\hline RPS19 & $\begin{array}{l}\text { Associated with HP1a } \\
\text { Found in the insoluble nuclear fraction }\end{array}$ & Humans, flies, and plants & {$[25,26,42,158]$} \\
\hline RPS20 & $\begin{array}{c}\text { Binds Mdm2 } \\
\text { Involved in RNAP III transcription } \\
\text { Associated with HP1a } \\
\text { Associated with RNAP II } \\
\text { Chromatin-associated } \\
\text { Found in the insoluble nuclear fraction }\end{array}$ & Mammals, flies, and yeasts & {$[33,42,158,163,186,216]$} \\
\hline RPS21 & $\begin{array}{l}\text { Chromatin-associated } \\
\text { Found in the insoluble nuclear fraction }\end{array}$ & Mammals and plants & {$[26,33,42]$} \\
\hline RPS23 & $\begin{array}{l}\text { Associated with HP1a } \\
\text { Associated with histone H1 } \\
\text { Chromatin-associated }\end{array}$ & Mammals, flies, and plants & {$[25,33,157,158]$} \\
\hline RPS24 & $\begin{array}{c}\text { Localized at active loci on chromosomes } \\
\text { Associated with TFIIIE } \\
\text { Associated with HP1a } \\
\text { Associated with RNAP II } \\
\text { Associated with histone H1 } \\
\text { Chromatin-associated } \\
\text { Found in the insoluble nuclear fraction }\end{array}$ & Mammals, flies, and plants & $\begin{array}{c}{[25,26,33,42,149,150,157} \\
158,216]\end{array}$ \\
\hline RPS25 & $\begin{array}{c}\text { Binds Mdm2 } \\
\text { Associated with TFIIIE } \\
\text { Associated with HP1a } \\
\text { Associated with RNAP II } \\
\text { Chromatin-associated } \\
\text { Found in the insoluble nuclear fraction } \\
\text { Found in nuclei of sperm }\end{array}$ & Mammals, flies, yeasts, and plants & $\begin{array}{c}{[25,26,33,42,158,160,161} \\
186,216]\end{array}$ \\
\hline RPS26 & $\begin{array}{c}\text { Interacts with Mdm2, p53, and p300 } \\
\text { Suppression of splicing of its own pre-mRNA } \\
\text { Associated with HP1a } \\
\text { Associated with RNAP II } \\
\text { Chromatin-associated }\end{array}$ & Mammals, flies, and plants & $\begin{array}{c}{[25,26,33,158,186,202,216} \\
309]\end{array}$ \\
\hline RPS27 & $\begin{array}{l}\text { Binds FANCD2 and FANCI } \\
\text { Binds Mdm2 } \\
\text { Associated with RNAP II } \\
\text { Chromatin-associated }\end{array}$ & Mammals and plants & {$[26,33,131,186,216]$} \\
\hline RPS27A & $\begin{array}{l}\text { Binds Mdm2 } \\
\text { Chromatin-associated }\end{array}$ & Mammals and plants & {$[25,33,192,205]$} \\
\hline RPS28 & $\begin{array}{c}\text { Chromatin-associated } \\
\text { Associated with RNAP II } \\
\text { Component of interchromatin granule clusters }\end{array}$ & Mammals and plants & {$[26,33,40,216]$} \\
\hline RPS29 & Associated with HP1a & Flies & [158] \\
\hline RPS30 & Localized at active loci on chromosomes & Flies and plants & {$[26,149,150]$} \\
\hline RPLP0 & $\begin{array}{c}\text { Interacts with APE1/Ref-1 } \\
\text { Endonuclease activity } \\
\text { Modifies position effect variegation } \\
\text { Associated with HP1a } \\
\text { Associated with RNAP II } \\
\text { Associated with histone H1 } \\
\text { Chromatin-associated } \\
\text { Component of interchromatin granule clusters } \\
\text { Found in the insoluble nuclear fraction }\end{array}$ & Mammals and flies & $\begin{array}{c}{[33,40,42,54,132,133,157} \\
158,211,216]\end{array}$ \\
\hline RPLP1 & $\begin{array}{c}\text { Intrinsic transactivation potential } \\
\text { Associated with HP1a } \\
\text { Chromatin-associated } \\
\text { Component of interchromatin granule clusters }\end{array}$ & Mammals, flies, yeasts, and plants & {$[25,26,33,40,158,171]$} \\
\hline
\end{tabular}


Table 1. Cont.

\begin{tabular}{|c|c|c|c|}
\hline $\begin{array}{c}\text { Protein (RP Names are Indicated } \\
\text { According to [3]) }\end{array}$ & $\begin{array}{c}\text { Nuclear Functions } \\
\text { (Pooled Data for All Species) }\end{array}$ & $\begin{array}{l}\text { Species in which Nuclear } \\
\text { Localization Was Detected }\end{array}$ & References \\
\hline RPLP2 & $\begin{array}{l}\text { Intrinsic transactivation potential } \\
\text { Associated with HP1a } \\
\text { Chromatin-associated } \\
\text { Found in the insoluble nuclear fraction }\end{array}$ & Mammals, flies, yeasts, and plants & {$[25,26,33,42,158,171]$} \\
\hline RPL3 & $\begin{array}{c}\text { Control of DNA repair } \\
\text { Binds Sp1 } \\
\text { Downregulates E2F1-dependent promoters by } \\
\text { sequestering PARP1 } \\
\text { Controls alternative splicing of its own pre-mRNA } \\
\text { Associated with HP1a } \\
\text { Associated with RNAP II } \\
\text { Associated with histone H1 } \\
\text { Chromatin-associated } \\
\text { Found in the chromosome scaffold fraction } \\
\text { Found in the insoluble nuclear fraction } \\
\text { Found in nuclei of sperm }\end{array}$ & Mammals, flies, and plants & $\begin{array}{c}{[26,33,41,42,97,135,157,158,} \\
160,166,206,216,310,321, \\
\text { 322] }\end{array}$ \\
\hline RPL4 & $\begin{array}{c}\text { Suppression of splicing of its own pre-mRNA } \\
\text { Binds Mdm2, EBNA1 } \\
\text { Associated with HP1a } \\
\text { Associated with RNAP II } \\
\text { Associated with histone H1 } \\
\text { Chromatin-associated } \\
\text { Component of interchromatin granule clusters } \\
\text { Found in the chromosome scaffold fraction } \\
\text { Found in the insoluble nuclear fraction }\end{array}$ & Mammals, frogs, flies, and plants & $\begin{array}{c}{[26,33,40-} \\
42,142,157,158,187,216,311]\end{array}$ \\
\hline RPL5 & $\begin{array}{c}\text { Determines nucleolar localization of the NVL2 } \\
\text { Interacts with splicing factor SRSF1 } \\
\text { Binds Mdm2 and SPIN1 } \\
\text { Induces transcriptional activity of TAp73 } \\
\text { Participates in telomere length set point } \\
\text { Associated with HP1a } \\
\text { Associated with RNAP II } \\
\text { Associated with histone H1 } \\
\text { Chromatin-associated } \\
\text { Found in the insoluble nuclear fraction } \\
\text { Localized at active loci on chromosomes }\end{array}$ & Mammals, flies, and plants & $\begin{array}{c}{[25,26,33,42,87,88,140,149,} \\
150,157,158,166,186,195, \\
201,207,216,375]\end{array}$ \\
\hline RPL6 & $\begin{array}{c}\text { Interacts with histone } \mathrm{H} 2 \mathrm{~A} / \mathrm{H} 2 \mathrm{AX} \\
\text { Recruited to DNA damage sites, mediates } \\
\text { recruitment of repair proteins } \\
\text { Binds Mdm2 } \\
\text { Mediates DNA binding of Tax } \\
\text { Associated with TFIIIE } \\
\text { Associated with HP1a } \\
\text { Associated with RNAP II } \\
\text { Associated with histone H1 } \\
\text { Chromatin-associated } \\
\text { Found in the insoluble nuclear fraction }\end{array}$ & Mammals, flies, yeasts, and plants & $\begin{array}{c}{[25,26,33,42,130,157,158,} \\
161,175,190,216]\end{array}$ \\
\hline
\end{tabular}

Associated with centromeres

Localized at active loci on chromosomes

Counteracts the binding of VDR-RXR to DNA

Associated with nascent mRNA

Interacts with histone $\mathrm{H} 1$

RPL7 Associated with TFIIIE

Associated with HP1a

Associated with RNAP II

Associated with histone $\mathrm{H} 1$

Chromatin-associated

Found in the insoluble nuclear fraction

Localized at active loci on chromosomes

Associated with HP1a

Associated with RNAP II

RPL7A Associated with histone $\mathrm{H}$

Chromatin-associated

Mammals, flies, and plants

$[26,33,40,42,149,150,157$, $158,216]$

Component of interchromatin granule clusters

Found in the insoluble nuclear fraction

Recruited to DNA damage sites

Localized at active loci on chromosomes

Associated with HP1a

RPL8

Associated with RNAP II

Associated with histone $\mathrm{H}$

Chromatin-associated

Mammals, flies, yeasts, and plants

$[26,33,42,149-152,155,157$ $158,161,176,216]$

Component of interchromatin granule clusters 
Table 1. Cont.

\begin{tabular}{|c|c|c|c|}
\hline $\begin{array}{c}\text { Protein (RP Names are Indicated } \\
\text { According to [3]) }\end{array}$ & $\begin{array}{c}\text { Nuclear Functions } \\
\text { (Pooled Data for All Species) }\end{array}$ & $\begin{array}{l}\text { Species in which Nuclear } \\
\text { Localization Was Detected }\end{array}$ & References \\
\hline RPL9 & $\begin{array}{c}\text { Participates in intranuclear traffic of Gag protein } \\
\text { Associated with HP1a } \\
\text { Associated with RNAP II } \\
\text { Chromatin-associated } \\
\text { Found in the insoluble nuclear fraction } \\
\text { Found in nuclei of sperm }\end{array}$ & Mammals, flies, and plants & $\begin{array}{c}{[26,33,42,102,109,158,160} \\
216]\end{array}$ \\
\hline RPL10 & $\begin{array}{c}\text { Suppression of the binding of c-Jun homodimer } \\
\text { to DNA } \\
\text { Associated with RNAP II } \\
\text { Associated with histone H1 } \\
\text { Chromatin-associated } \\
\text { Found in the insoluble nuclear fraction }\end{array}$ & Mammals and plants & $\begin{array}{c}{[25,26,33,42,94,95,157,178} \\
216]\end{array}$ \\
\hline RPL10A & $\begin{array}{c}\text { Interacts with LIMYB and downregulates } \\
\text { expression of RP genes } \\
\text { Suppression of splicing of its own pre-mRNA } \\
\text { Associated with HP1a } \\
\text { Associated with RNAP II } \\
\text { Found in the insoluble nuclear fraction }\end{array}$ & Humans, flies, and plants & {$[42,158,173,174,216,312]$} \\
\hline RPL11 & $\begin{array}{c}\text { Binds c-myc, Mdm2, ARF, GRWD1, PML, } \\
\text { and PICT1 } \\
\text { Induces transcriptional activity of TAp73 } \\
\text { Counteracts binding of PPAR } \alpha \text { DNA } \\
\text { Stimulates p53-mediated transcription } \\
\text { Induces apoptosis } \\
\text { Nucleolar localization promotes } \\
\text { tumor progression } \\
\text { Association with centromeres } \\
\text { Localized at active loci on chromosomes } \\
\text { Required for integrity of the nucleolar structure } \\
\text { Associated with HP1a } \\
\text { Associated with RNAP II } \\
\text { Chromatin-associated } \\
\text { Found in the insoluble nuclear fraction }\end{array}$ & Mammals, flies, yeasts, and plants & $\begin{array}{c}{[25,26,33,42,84,110,149-} \\
151,158,162,164,166,177 \\
186,195,196,199,200,207 \\
216,372-374]\end{array}$ \\
\hline RPL12 & $\begin{array}{l}\text { Localized at active loci on chromosomes } \\
\text { Interacts with Corto } \\
\text { Required for transcription of the PHO } \\
\text { pathway genes } \\
\text { Suppression of splicing of its own pre-mRNA } \\
\text { Associated with HP1a } \\
\text { Associated with histone H1 } \\
\text { Chromatin-associated } \\
\text { Component of interchromatin granule clusters } \\
\text { Found in the insoluble nuclear fraction }\end{array}$ & $\begin{array}{c}\text { Mammals, flies, worms, yeasts, and } \\
\text { plants }\end{array}$ & $\begin{array}{l}{[26,33,40,42,149,150,154} \\
\quad 157,158,209,210,313]\end{array}$ \\
\hline
\end{tabular}

Promotes activity of $N F-\kappa B$ and IFN- $\beta$ promoters

Associated with TFIIIE

RPL13 Associated with RNAP II

Associated with HP1a

Chromatin-associated

Mammals, flies, yeasts, and plants $\quad[25,26,33,40,42,158,161,172$, 216]

Component of interchromatin granule clusters

Found in the insoluble nuclear fraction

\begin{tabular}{|c|c|c|c|}
\hline RPL13A & $\begin{array}{l}\text { Associated with HP1a } \\
\text { Associated with RNAP II } \\
\text { Found in the insoluble nuclear fraction }\end{array}$ & Humans and flies & {$[42,158,216]$} \\
\hline RPL14 & $\begin{array}{c}\text { Localized at active loci on chromosomes } \\
\text { Associated with TFIIIE } \\
\text { Associated with HP1a } \\
\text { Associated with RNAP II } \\
\text { Chromatin-associated } \\
\text { Component of interchromatin granule clusters } \\
\text { Found in the insoluble nuclear fraction }\end{array}$ & Mammals, flies, yeasts, and plants & $\begin{array}{c}{[25,26,33,40,42,149,150,158,} \\
161,216]\end{array}$ \\
\hline RPL15 & $\begin{array}{l}\text { Required for integrity of the nucleolar structure } \\
\text { Localized at active loci on chromosomes } \\
\text { Associated with HP1a } \\
\text { Associated with RNAP II } \\
\text { Chromatin-associated } \\
\text { Component of interchromatin granule clusters } \\
\text { Found in the insoluble nuclear fraction }\end{array}$ & Mammals, flies, and plants & $\begin{array}{c}{[26,33,40,42,84,149,150,158,} \\
216]\end{array}$ \\
\hline RPL17 & $\begin{array}{c}\text { Localized at active loci on chromosomes } \\
\text { Associated with HP1a } \\
\text { Associated with histone H1 } \\
\text { Chromatin-associated } \\
\text { Found in the insoluble nuclear fraction }\end{array}$ & Mammals, flies, and plants & {$[26,33,42,149,150,157,158]$} \\
\hline
\end{tabular}


Table 1. Cont.

\begin{tabular}{|c|c|c|c|}
\hline $\begin{array}{c}\text { Protein (RP Names are Indicated } \\
\text { According to [3]) }\end{array}$ & $\begin{array}{c}\text { Nuclear Functions } \\
\text { (Pooled Data for All Species) }\end{array}$ & $\begin{array}{l}\text { Species in which Nuclear } \\
\text { Localization Was Detected }\end{array}$ & References \\
\hline RPL18 & $\begin{array}{c}\text { Localized at active loci on chromosomes } \\
\text { Associated with HP1a } \\
\text { Associated with histone H1 } \\
\text { Chromatin-associated } \\
\text { Found in the insoluble nuclear fraction }\end{array}$ & Mammals, flies, and plants & $\begin{array}{c}{[25,26,33,42,149,150,157} \\
158]\end{array}$ \\
\hline RPL18A & $\begin{array}{c}\text { Associated with HP1a } \\
\text { Associated with RNAP II } \\
\text { Found in the insoluble nuclear fraction }\end{array}$ & Humans, flies, and plants & {$[25,26,42,158,216]$} \\
\hline RPL19 & $\begin{array}{c}\text { Interacts with ERH } \\
\text { Associated with HP1a } \\
\text { Associated with RNAP II } \\
\text { Chromatin-associated } \\
\text { Component of interchromatin granule clusters } \\
\text { Found in the insoluble nuclear fraction }\end{array}$ & Mammals, flies, and plants & $\begin{array}{c}{[25,26,33,40,42,108,158,} \\
216]\end{array}$ \\
\hline RPL21 & $\begin{array}{c}\text { Associated with HP1a } \\
\text { Associated with RNAP II } \\
\text { Associated with histone H1 } \\
\text { Chromatin-associated } \\
\text { Found in the insoluble nuclear fraction }\end{array}$ & Mammals, flies, and plants & {$[25,26,33,42,157,158,216]$} \\
\hline RPL22 & $\begin{array}{c}\text { Binds Mdm2 } \\
\text { Participates in alternative splicing of smad2 } \\
\text { pre-mRNA } \\
\text { Suppression of splicing of paralog pre-mRNA } \\
\text { Interacts with histone H1 } \\
\text { Associated with HP1a } \\
\text { Associated with RNAP II } \\
\text { Associated with histone H1 } \\
\text { Chromatin-associated }\end{array}$ & Mammals, fish, flies, and plants & $\begin{array}{l}{[25,26,33,98-100,155,157} \\
158,193,216,314,323,324]\end{array}$ \\
\hline RPL23 & $\begin{array}{c}\text { Binds Mdm2 and nucleophosmin } \\
\text { Associated with HP1a } \\
\text { Chromatin-associated } \\
\text { Component of interchromatin granule clusters } \\
\text { Found in the insoluble nuclear fraction }\end{array}$ & Humans, flies, and plants & $\begin{array}{c}{[25,26,33,40,42,106,158,186,} \\
242]\end{array}$ \\
\hline RPL23A & $\begin{array}{c}\text { Localized at active loci on chromosomes } \\
\text { Associated with HP1a } \\
\text { Associated with RNAP II } \\
\text { Chromatin-associated } \\
\text { Component of interchromatin granule clusters } \\
\text { Found in the insoluble nuclear fraction }\end{array}$ & Mammals, flies, and plants & {$[25,33,40,42,151,158,216]$} \\
\hline RPL24 & $\begin{array}{c}\text { Binds pre-miRNA and facilitates its processing } \\
\text { Associated with HP1a } \\
\text { Associated with RNAP II } \\
\text { Chromatin-associated } \\
\text { Found in the insoluble nuclear fraction }\end{array}$ & Mammals, flies, and plants & {$[25,26,33,42,158,216,327]$} \\
\hline RPL26 & $\begin{array}{c}\text { Participates in alternative splicing of } p 53 \\
\text { pre-mRNA } \\
\text { Binds Mdm2 } \\
\text { Associated with nascent mRNA } \\
\text { Associated with TFIIIE } \\
\text { Associated with HP1a } \\
\text { Chromatin-associated } \\
\text { Found in the insoluble nuclear fraction }\end{array}$ & Mammals, flies, and yeasts & {$[33,42,152,158,161,186,325]$} \\
\hline RPL27 & $\begin{array}{l}\text { Associated with HP1a } \\
\text { Chromatin-associated } \\
\text { Found in the insoluble nuclear fraction }\end{array}$ & Mammals, flies, and plants & {$[25,26,33,42,158]$} \\
\hline RPL27A & $\begin{array}{c}\text { Associated with HP1a } \\
\text { Associated with histone H1 } \\
\text { Chromatin-associated } \\
\text { Component of interchromatin granule clusters } \\
\text { Found in the insoluble nuclear fraction }\end{array}$ & Mammals and flies & {$[33,40,42,157,158]$} \\
\hline RPL28 & $\begin{array}{c}\text { Localized at active loci on chromosomes } \\
\text { Associated with HP1a } \\
\text { Associated with RNAP II } \\
\text { Chromatin-associated }\end{array}$ & Mammals, flies, and plants & $\begin{array}{c}{[25,26,33,88,149,150,158,} \\
216]\end{array}$ \\
\hline RPL29 & $\begin{array}{c}\text { Associated with HP1a } \\
\text { Associated with RNAP II }\end{array}$ & Humans, flies, and plants & {$[25,26,158,216]$} \\
\hline RPL30 & $\begin{array}{c}\text { Suppression of splicing of its own pre-mRNA } \\
\text { Associated with HP1a } \\
\text { Associated with RNAP II } \\
\text { Associated with histone H1 } \\
\text { Chromatin-associated }\end{array}$ & Mammals, flies, yeasts, and plants & $\begin{array}{c}{[25,26,33,157,158,216,315,} \\
316]\end{array}$ \\
\hline
\end{tabular}


Table 1. Cont.

\begin{tabular}{|c|c|c|c|}
\hline $\begin{array}{c}\text { Protein (RP Names are Indicated } \\
\text { According to [3]) }\end{array}$ & $\begin{array}{c}\text { Nuclear Functions } \\
\text { (Pooled Data for All Species) }\end{array}$ & $\begin{array}{l}\text { Species in which Nuclear } \\
\text { Localization Was Detected }\end{array}$ & References \\
\hline RPL31 & $\begin{array}{c}\text { Associated with HP1a } \\
\text { Associated with RNAP II } \\
\text { Chromatin-associated } \\
\text { Component of interchromatin granule clusters } \\
\text { Found in the insoluble nuclear fraction }\end{array}$ & Mammals, flies, and plants & {$[26,33,40,42,158,216]$} \\
\hline RPL32 & $\begin{array}{c}\text { Suppression of splicing of its own pre-mRNA } \\
\text { Localized at active loci on chromosomes } \\
\text { Associated with HP1a } \\
\text { Associated with RNAP II } \\
\text { Chromatin-associated } \\
\text { Found in the insoluble nuclear fraction }\end{array}$ & Mammals, flies, and plants & $\begin{array}{c}{[25,26,33,42,149,150,158} \\
216,317,318]\end{array}$ \\
\hline RPL34 & $\begin{array}{c}\text { Localized at active loci on chromosomes } \\
\text { Associated with nascent mRNA } \\
\text { Associated with HP1a } \\
\text { Associated with RNAP II }\end{array}$ & Humans, flies, yeasts, and plants & {$[25,26,149,150,152,158,216]$} \\
\hline RPL35 & $\begin{array}{c}\text { Associated with HP1a } \\
\text { Associated with RNAP II } \\
\text { Chromatin-associated } \\
\text { Component of interchromatin granule clusters } \\
\text { Found in the insoluble nuclear fraction }\end{array}$ & Mammals, flies, and plants & {$[26,33,40,42,158,216]$} \\
\hline RPL35A & $\begin{array}{l}\text { Associated with HP1a } \\
\text { Associated with RNAP II } \\
\text { Chromatin-associated }\end{array}$ & Mammals, flies, and plants & {$[26,33,158,216]$} \\
\hline RPL36 & $\begin{array}{c}\text { Localized at active loci on chromosomes } \\
\text { Associated with TFIIIE } \\
\text { Associated with HP1a } \\
\text { Associated with RNAP II } \\
\text { Chromatin-associated }\end{array}$ & Mammals, flies, yeasts, and plants & $\begin{array}{c}{[25,26,33,149,150,158,161} \\
216]\end{array}$ \\
\hline RPL36A & Chromatin-associated & Mammals & [33] \\
\hline RPL37 & Binds Mdm2 & Humans & {$[186,203]$} \\
\hline RPL37A & $\begin{array}{l}\text { Associated with HP1a } \\
\text { Chromatin-associated }\end{array}$ & Mammals and flies & {$[33,158]$} \\
\hline RPL38 & Chromatin-associated & Mammals and plants & {$[26,33]$} \\
\hline RPL39 & Localized at active loci on chromosomes & Flies and plants & {$[26,149,150]$} \\
\hline RPL41 & Induces export of ATF4 from nuclei & Humans & [246] \\
\hline eIF1 & Chromatin-associated & Mammals & {$[27,33]$} \\
\hline eIF1A & Chromatin-associated & Mammals, flies, and yeasts & {$[20,22,27,28,33]$} \\
\hline $\begin{array}{c}\text { eIF2 } \\
\text { (S1-S3 subunits) }\end{array}$ & $\begin{array}{c}\text { Stabilization of DNA-PKcs-Ku complex } \\
\text { Controls RRN3/TIF-IA and RNAP I activity } \\
\text { Associated with HP1a } \\
\text { Associated with RNAP II } \\
\text { Chromatin-associated }\end{array}$ & Mammals, flies, yeasts, and plants & $\begin{array}{c}{[20,23,25,26,33,50-} \\
53,136,158,216,220]\end{array}$ \\
\hline eIF2A & $\begin{array}{c}\text { Associated with mRNA } 3^{\prime} \text {-processing complex } \\
\text { Chromatin-associated }\end{array}$ & Mammals & {$[33,332]$} \\
\hline $\begin{array}{c}\text { eIF2B } \\
\text { (1-5 subunits) }\end{array}$ & Chromatin-associated & Mammals and yeasts & {$[20,33,54]$} \\
\hline eIF3a & $\begin{array}{c}\text { Interacts with RNAP II } \\
\text { Associated with mRNA } 3^{\prime} \text {-processing complex } \\
\text { Associated with histone H1 } \\
\text { Chromatin-associated }\end{array}$ & Mammals and plants & {$[26,33,157,214,332]$} \\
\hline eIF3b & $\begin{array}{c}\text { Associated with mRNA } 3^{\prime} \text {-processing complex } \\
\text { Associated with histone H1 } \\
\text { Chromatin-associated }\end{array}$ & Mammals and plants & {$[26,33,54,157,332]$} \\
\hline eIF3c & $\begin{array}{c}\text { Interacts with RNAP II } \\
\text { Interacts with the nuclear COP9 signalosome } \\
\text { Chromatin-associated }\end{array}$ & Mammals, yeasts, and plants & {$[26,33,49,54,215]$} \\
\hline eIF3d & $\begin{array}{l}\text { Associated with HP1a } \\
\text { Chromatin-associated }\end{array}$ & Mammals, flies, yeasts, and plants & {$[20,26,33,158]$} \\
\hline
\end{tabular}


Table 1. Cont.

\begin{tabular}{|c|c|c|c|}
\hline $\begin{array}{c}\text { Protein (RP Names are Indicated } \\
\text { According to [3]) }\end{array}$ & $\begin{array}{c}\text { Nuclear Functions } \\
\text { (Pooled Data for All Species) }\end{array}$ & $\begin{array}{l}\text { Species in which Nuclear } \\
\text { Localization Was Detected }\end{array}$ & References \\
\hline eIF3e & $\begin{array}{c}\text { Participates in DNA repair } \\
\text { Interacts with ATM } \\
\text { Promotes loading of the RAD51 } \\
\text { Interacts with Ub-MCM7 } \\
\text { Interacts with the nuclear COP9 } \\
\text { in the nucleus } \\
\text { signalosomeProper accumulation of proteasome } \\
\text { Interacts with Rfp, HIF-2 } \alpha \\
\text { Increases the transcriptional activity of Pap1 } \\
\text { Colocalized in certain PML nuclear bodies } \\
\text { Copurifies with CBP80 } \\
\text { Associated with mRNA 3'-processing complex } \\
\text { Chromatin-associated }\end{array}$ & Mammals and plants & $\begin{array}{c}{[26,33,38,45-48,70,137,138,} \\
141,221,249,332,335,379]\end{array}$ \\
\hline eIF3f & $\begin{array}{c}\text { Cooperates with STAT3 and other TFs } \\
\text { Associated with mRNA } 3^{\prime} \text {-processing complex } \\
\text { Colocalized in nucleus with CDK11 } \\
\text { Chromatin-associated }\end{array}$ & Mammals and plants & {$[24-26,33,157,222-224,332]$} \\
\hline eIF3g & Chromatin-associated & Mammals, yeasts, and plants & {$[20,25,26,33,54]$} \\
\hline eIF3h & $\begin{array}{c}\text { Enhancer of variegation function } \\
\text { Associated with mRNA } 3^{\prime} \text {-processing complex } \\
\text { Chromatin-associated }\end{array}$ & Mammals and plants & {$[26,33,225,332]$} \\
\hline eIF3i & $\begin{array}{c}\text { Interacts with RNAP II } \\
\text { Associated with mRNA } 3^{\prime} \text {-processing complex } \\
\text { Associated with histone H1 } \\
\text { Chromatin-associated }\end{array}$ & Mammals and yeasts & {$[20,33,157,214,332]$} \\
\hline eIF3j & Interacts with RNAP II & Yeasts & [215] \\
\hline eIF3k & $\begin{array}{l}\text { Colocalized with PML bodies } \\
\text { Interacts with cyclin D3 }\end{array}$ & Humans and plants & {$[26,36,37]$} \\
\hline eIF31 & $\begin{array}{l}\text { Cofactor of RNAP I } \\
\text { Associated with histone H1 } \\
\text { Chromatin-associated }\end{array}$ & Mammals & {$[33,157,218,219]$} \\
\hline eIF3m & $\begin{array}{l}\text { Interacts with RNAP II } \\
\text { Chromatin-associated }\end{array}$ & Mammals & {$[33,214]$} \\
\hline eIF4E & $\begin{array}{c}\text { Defines specific pathway of mRNA export } \\
\text { Binds LRPPRC } \\
\text { Interacts with PML } \\
\text { Interacts with factors of mRNA } 3^{\prime} \text {-processing } \\
\text { Participates in mRNA biogenesis } \\
\text { Stimulates mRNA capping and } \\
\text { alternative splicing } \\
\text { Associated with splicing factors } \\
\text { Participates in cancer cell transformation }\end{array}$ & $\begin{array}{l}\text { Humans, flies, frogs, yeasts, and } \\
\text { plants }\end{array}$ & $\begin{array}{c}{[17-19,24-} \\
26,32,39,65,66,329-331,354- \\
359,380-383]\end{array}$ \\
\hline eIF4A & $\begin{array}{c}\text { Associated with mRNA } 3^{\prime} \text {-processing complex } \\
\text { Interacts with CBP80 } \\
\text { Presumable role in splicing } \\
\text { Associated with HP1a and HP1c } \\
\text { Associated with RNAP II } \\
\text { Chromatin-associated } \\
\text { Component of interchromatin granule clusters } \\
\text { Found in the insoluble nuclear fraction }\end{array}$ & Mammals, flies, and plants & $\begin{array}{c}{[25,26,33,34,40,42,71,158} \\
159,216,332,336,337]\end{array}$ \\
\hline eIF4G & $\begin{array}{c}\text { Associated with mRNA } 3^{\prime} \text {-processing complex } \\
\text { Interacts with the nuclear CBC } \\
\text { and splicing factors } \\
\text { Localized in XY body of spermatocytes } \\
\text { Associated with HP1a } \\
\text { Associated with RNAP II } \\
\text { Chromatin-associated }\end{array}$ & Mammals, flies, and plants & $\begin{array}{c}{[25,26,33,54,72,158,216,332} \\
342-344]\end{array}$ \\
\hline eIF4B & $\begin{array}{l}\text { Associated with HP1a } \\
\text { Chromatin-associated }\end{array}$ & Mammals, flies, and plants & {$[26,33,54,158]$} \\
\hline eIF4H & Chromatin-associated & Mammals & [33] \\
\hline eIF5 & Chromatin-associated & Mammals and plants & {$[24,33]$} \\
\hline eIF5B & $\begin{array}{l}\text { Active transcription sites } \\
\text { Associated with RNAP II } \\
\text { Associated with histone H1 }\end{array}$ & Humans, flies, and plants & {$[26,54,150,157,216]$} \\
\hline eIF6 & $\begin{array}{l}\text { Participates in ribosome biogenesis } \\
\text { Associated with RNAP II } \\
\text { Chromatin-associated } \\
\text { Found in the insoluble nuclear fraction }\end{array}$ & Mammals, frogs, yeasts, and plants & $\begin{array}{c}{[20,21,25-27,30,32-} \\
34,42,106,216]\end{array}$ \\
\hline
\end{tabular}


Table 1. Cont.

\begin{tabular}{|c|c|c|c|}
\hline $\begin{array}{c}\text { Protein (RP Names are Indicated } \\
\text { According to [3]) }\end{array}$ & $\begin{array}{c}\text { Nuclear Functions } \\
\text { (Pooled Data for All Species) }\end{array}$ & $\begin{array}{l}\text { Species in which Nuclear } \\
\text { Localization Was Detected }\end{array}$ & References \\
\hline eEF1A & $\begin{array}{c}\text { Stimulates the recruitment of HSF1 to DNA and } \\
\text { activity of } H S P 70 \\
\text { Recruited to IFN- } \gamma \text { promoter and } \\
\text { stimulates transcription } \\
\text { Interacts with ZPR1, RNAP II, Zw5, ZIPIC, } \\
\text { and Grau } \\
\text { Promotes nuclear export of Sox10 and Snail } \\
\text { Stabilizes RNAP II-TAR RNA interaction } \\
\text { Associated with mRNA 3'-processing complex } \\
\text { Defines a specific protein export pathway } \\
\text { mRNA export, tRNA re-export } \\
\text { Associated with HP1a } \\
\text { Chromatin-associated } \\
\text { Found in the insoluble nuclear fraction }\end{array}$ & Humans, flies, yeasts, and plants & $\begin{array}{c}{[20,24,27,33,34,42,158,216,} \\
227-235,253-258,332- \\
334,390-392]\end{array}$ \\
\hline $\mathrm{eEF} 1 \mathrm{~B} \beta$ & $\begin{array}{c}\text { Chromatin-associated } \\
\text { Putative role in transcription, splicing, and DNA } \\
\text { damage response }\end{array}$ & Mammals and plants & {$[25,26,33,236,392]$} \\
\hline eEF1B $\gamma$ & $\begin{array}{l}\text { Putative role in splicing and control of mRNA } \\
\text { stability } \\
\text { Binds RNAP II and recruited to several promoters } \\
\text { Associated with mRNA } 3^{\prime} \text {-processing complex } \\
\text { Chromatin-associated } \\
\text { Found in the insoluble nuclear fraction }\end{array}$ & Mammals, flies, and plants & $\begin{array}{c}{[25,26,33,42,236-} \\
239,332,392]\end{array}$ \\
\hline eEF1B $\delta$ & Chromatin-associated & Mammals and plants & {$[26,33]$} \\
\hline eEF2 & $\begin{array}{c}\text { Induces nuclear morphological changes } \\
\text { and aneuploidy } \\
\text { Associated with HP1a } \\
\text { Chromatin-associated } \\
\text { Found in the insoluble nuclear fraction }\end{array}$ & Mammals, flies, and plants & {$[25,26,33,42,148,158]$} \\
\hline eIF5A & $\begin{array}{c}\text { Induction of apoptosis } \\
\text { Associated with intranuclear filaments of NPC } \\
\text { Binds the promoter of the HIF1 } \alpha \text { and activates } \\
\text { its transcription } \\
\text { Part of a specific RNA nuclear export pathway } \\
\text { Associated with oncogenesis } \\
\text { Associated with HP1a } \\
\text { Chromatin-associated } \\
\text { Found in the insoluble nuclear fraction }\end{array}$ & Mammals, flies, yeasts, and plants & $\begin{array}{c}{[20,25,26,33,42,55-} \\
64,158,226,361-369,384- \\
389]\end{array}$ \\
\hline eEFSec & Unknown & Humans and frogs & {$[31,32]$} \\
\hline eRF1 & $\begin{array}{l}\text { The quality control mechanism of } \\
\text { maturing ribosomes } \\
\text { Chromatin-associated }\end{array}$ & Mammals, yeasts, and plants & {$[20,25,35]$} \\
\hline eRF3 & $\begin{array}{c}\text { Found at active transcription sites } \\
\text { Chromatin-associated }\end{array}$ & Mammals and flies & [150] \\
\hline
\end{tabular}
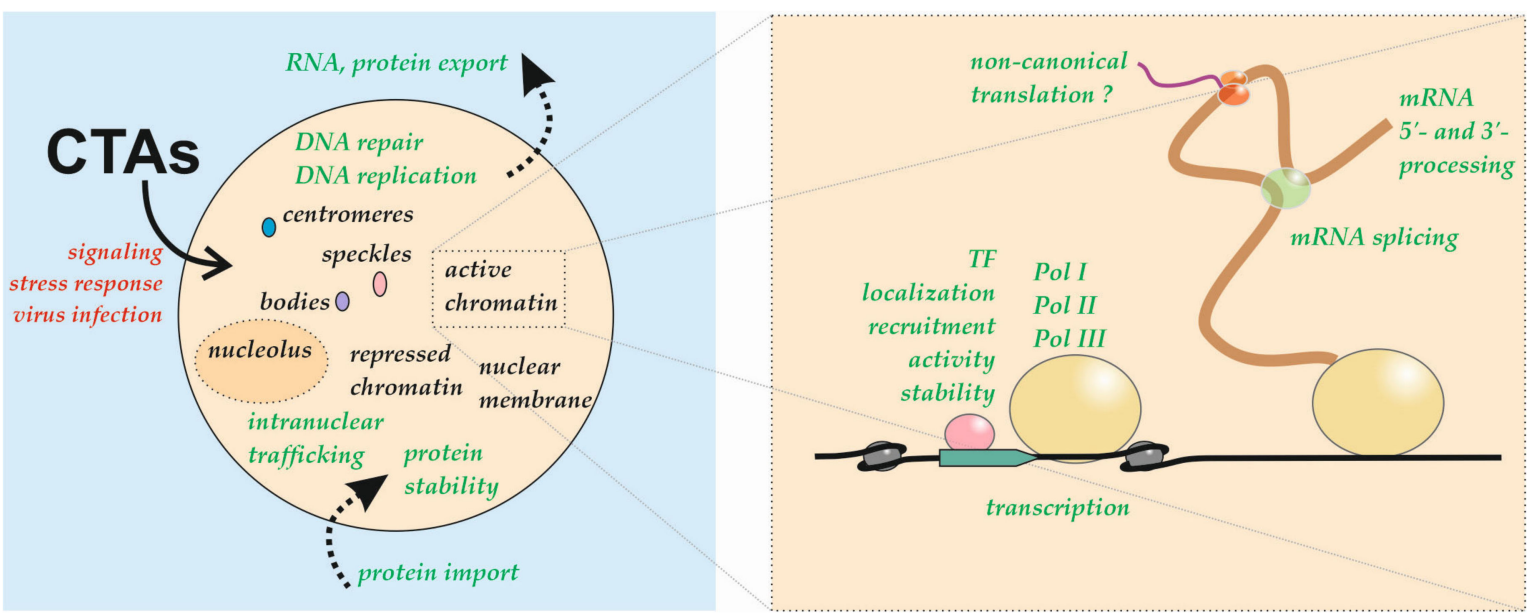

Figure 1. Components of the translation apparatus (CTAs) relocalize to the nucleus under various conditions (red). The intranuclear localization (black) and nuclear processes (green) in which CTAs participate are indicated. TF, transcription factor; Pol, RNA polymerase. 
The functional significance of some of CTAs in nuclei has been studied in detail, whereas the roles of others remain to be clarified. Despite a significant amount of experimental data in this field, general concepts of CTA functioning in the cell nucleus are poorly developed. The mechanisms through which translation factors are imported into the nucleus are unknown for many factors. Our analysis of predicted NLS patterns in core translation factors expressed in humans (NLSdb tool [409] was used) did not identify an NLS in most cases, which may be due to the poor prediction abilities of this instrument. Another possibility involves the joint import of translation factors with specific partners, as described for eIF4E.

Whether CTAs in the nucleus function as independent proteins or as components of larger complexes requires further study; for example, the subunits of eIF3 display various nuclear functions, but their cooperation in the nucleus remains unclear. A hypothesis regarding differences in the nuclear and cytoplasmic eIF3 complex variants was suggested [224].

One obvious functional output of the nuclear localization of specific CTAs is the prevention of interactions with cytosolic CTAs, disrupting cellular translation, as was demonstrated for PABPC. However, in most cases, nuclear CTAs appear to possess specific nuclear functions.

CTAs in the nucleus are involved in multiple processes, including genome integrity control, DNA repair, replication, and nuclear stages of gene expression. Participation in gene expression appears to be the predominant function, including the regulation of TF DNA binding, TF activity and stability, and mRNA synthesis, processing, splicing, and export. An association between CTAs and silent chromatin was also shown. At the molecular level, CTAs bind proteins and RNAs, control their intranuclear localization, and modulate their interactions and activities.

CTAs contribute to the formation and function of some subnuclear structures, particularly the nucleolus, which plays an important role in the control of protein trafficking and many forms of the stress response [410]. Biochemical purifications showed an association between CTAs and architectural nuclear structures, indicating a putative structural function for CTAs (particularly RPs).

The nuclear localization of CTAs in many cases is regulated by external stimuli and internal pathways, which likely accounts for discrepancies observed in nuclear localization data reported by different studies, as the nuclear entry of a CTA may be induced by different signals in different cell types. In this model, CTAs may play optional or compensatory roles in various nuclear processes. This mode of function is confirmed by the existence of exclusively nuclear CTAs paralogs (eIF1AD, eIF4A3, eEF1B8L, and PTI-1), which share the domains, involved in some nuclear processes. The auxiliary functions of CTAs are hijacked by viruses to run their own cellular programs. RPs are common viral targets during cellular infections [411].

CTAs are abundant cell proteins and represent the targets of various signaling pathways in the cytoplasm [412]. Thus, CTAs appear to serve as reliable tools for the delivery of certain messages to the nucleus, where they can modulate nuclear processes. RPs have been suggested to play a substantial role in the cell stress response due to extraribosomal functions [186,413]. Moreover, RPs are involved in the realization of specific gene expression patterns [414]. The integration of general CTAs into cell response pathways appears to be intrinsically related to their roles in cancer phenotype development. The misregulation of certain cellular cascades leads to oncogenesis, which is partially realized by the modulation of the nuclear functions of CTAs.

Some nuclear activities of CTAs are evidently related to their ability to bind or participate in RNA metabolism. Growing evidence has indicated the crucial role of RNA and RNA-binding proteins in nuclear structure and function [33,287,415-417]. RNA-binding proteins also contribute significantly to eukaryotic cell regulatory networks, which are particularly important for more complex eukaryotes [418]. 
In addition to CTAs with additional nuclear functions, as described here, various multifunctional factors can affect the steps of the gene expression process, many of which are RNA-binding factors. For example, multifunctional factor Ago2 is involved in translational regulation and multiple nuclear activities, including chromatin regulation, transcription repression and activation, splicing, and DNA repair [419]. The Y-box binding protein (YB1) protein regulates translation but is also involved in transcription, splicing, and DNA repair [420-422].

CTAs could be regarded as multifunctional or moonlighting proteins. Moonlighting proteins were initially proposed to coordinate several cellular activities and participate in the cellular response to environmental signals. Switching between functions occurs due to the binding of specific molecules, other protein partners, or modifications [423]. These features can clearly be observed for CTAs. Similar to other moonlighting proteins, most CTAs contribute significantly to the complexity of cellular metabolism and the cell stress response [424]. Finally, moonlighting proteins are often associated with diseases, especially cancer development $[425,426]$. An analysis of CTA functions strongly supports a view that virtually no protein in the cell has only one specific function, and almost all proteins can be regarded as multifunctional [427].

The relationship between transcription and translation in eukaryotes remains poorly understood [428]; however, a deep interconnection between these stages of protein expression is expected. An integrative response to stress at all levels of the gene expression process was recently described for Arabidopsis [429]. A systematic analysis of protein-protein interactions predicted the extensive coupling of gene expression subprocesses, including translation, transcription, and mRNA metabolism [430]. CTAs and other multifunctional factors might serve as components of cellular mechanisms that couple the various stages of a global gene expression process. However, to date, the effects of specific CTAs at all stages of the gene expression process and the global interplay between CTAs have very rarely been investigated. Factors with integral effects on gene expression at various levels represent promising targets for applied research, including the development of treatments for viral infections and tumors.

In conclusion, the nuclear localization of CTAs is a common phenomenon and often serves as a cellular response to stress conditions and specific stimuli. Additional systematic and complex studies at all stages of gene expression examining the participation of multiple proteins and RNAs remain necessary to decipher this layer of the integrative cell response.

Author Contributions: Conceptualization, Z.M.K. and Y.V.S.; writing-original draft preparation, Z.M.K., S.D.I., E.N.K., L.A.L., Y.V.S.; writing—review and editing, Z.M.K. and Y.V.S.; supervision, Y.V.S.; project administration, Y.V.S.; funding acquisition, Y.V.S. All authors have read and agreed to the published version of the manuscript.

Funding: This research was funded by the Russian Foundation for Basic Research, grant number 19-34-51003.

Institutional Review Board Statement: Not applicable.

Informed Consent Statement: Not applicable.

Data Availability Statement: Data sharing not applicable.

Conflicts of Interest: The authors declare no conflict of interest. 


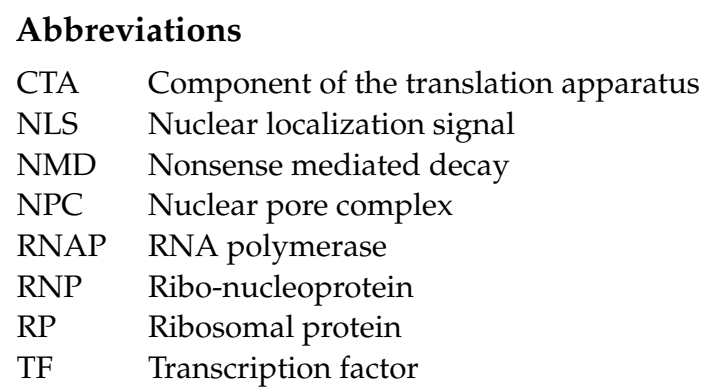

\section{References}

1. Jackson, R.J.; Hellen, C.U.; Pestova, T.V. The mechanism of eukaryotic translation initiation and principles of its regulation. Nat. Rev. Mol. Cell Biol. 2010, 11, 113-127. [CrossRef]

2. Lecompte, O.; Ripp, R.; Thierry, J.C.; Moras, D.; Poch, O. Comparative analysis of ribosomal proteins in complete genomes: An example of reductive evolution at the domain scale. Nucleic Acids Res. 2002, 30, 5382-5390. [CrossRef] [PubMed]

3. Nakao, A.; Yoshihama, M.; Kenmochi, N. RPG: The Ribosomal Protein Gene database. Nucleic Acids Res. 2004, 32, D168-D170. [CrossRef] [PubMed]

4. De la Cruz, J.; Karbstein, K.; Woolford, J.L., Jr. Functions of ribosomal proteins in assembly of eukaryotic ribosomes in vivo. Annu. Rev. Biochem. 2015, 84, 93-129. [CrossRef] [PubMed]

5. Perry, R.P. Balanced production of ribosomal proteins. Gene 2007, 401, 1-3. [CrossRef]

6. Xiao, L.; Grove, A. Coordination of Ribosomal Protein and Ribosomal RNA Gene Expression in Response to TOR Signaling. Curr. Genom. 2009, 10, 198-205. [CrossRef] [PubMed]

7. Pecoraro, A.; Pagano, M.; Russo, G.; Russo, A. Ribosome Biogenesis and Cancer: Overview on Ribosomal Proteins. Int. J. Mol. Sci. 2021, 22, 5496. [CrossRef] [PubMed]

8. Warner, J.R. The economics of ribosome biosynthesis in yeast. Trends Biochem. Sci. 1999, 24, 437-440. [CrossRef]

9. Petibon, C.; Malik Ghulam, M.; Catala, M.; Abou Elela, S. Regulation of ribosomal protein genes: An ordered anarchy. Wiley Interdiscip. Rev. RNA 2021, 12, e1632. [CrossRef] [PubMed]

10. Hao, P.; Yu, J.; Ward, R.; Liu, Y.; Hao, Q.; An, S.; Xu, T. Eukaryotic translation initiation factors as promising targets in cancer therapy. Cell Commun. Signal. 2020, 18, 175. [CrossRef] [PubMed]

11. Fukao, A.; Tomohiro, T.; Fujiwara, T. Translation Initiation Regulated by RNA-Binding Protein in Mammals: The Modulation of Translation Initiation Complex by Trans-Acting Factors. Cells 2021, 10, 1711. [CrossRef] [PubMed]

12. Atkinson, G.C. The evolutionary and functional diversity of classical and lesser-known cytoplasmic and organellar translational GTPases across the tree of life. BMC Genom. 2015, 16, 78. [CrossRef] [PubMed]

13. Marygold, S.J.; Attrill, H.; Lasko, P. The translation factors of Drosophila melanogaster. Fly 2017, 11, 65-74. [CrossRef] [PubMed]

14. Dever, T.E.; Green, R. The elongation, termination, and recycling phases of translation in eukaryotes. Cold Spring Harb Perspect. Biol. 2012, 4, a013706. [CrossRef]

15. Knight, J.R.P.; Garland, G.; Poyry, T.; Mead, E.; Vlahov, N.; Sfakianos, A.; Grosso, S.; De-Lima-Hedayioglu, F.; Mallucci, G.R.; von der Haar, T.; et al. Control of translation elongation in health and disease. Dis. Model Mech. 2020, 13, dmm043208. [CrossRef] [PubMed]

16. Genuth, N.R.; Barna, M. Heterogeneity and specialized functions of translation machinery: From genes to organisms. Nat. Rev. Genet. 2018, 19, 431-452. [CrossRef] [PubMed]

17. Lejbkowicz, F.; Goyer, C.; Darveau, A.; Neron, S.; Lemieux, R.; Sonenberg, N. A fraction of the mRNA $5^{\prime}$ cap-binding protein, eukaryotic initiation factor 4E, localizes to the nucleus. Proc. Natl. Acad. Sci. USA 1992, 89, 9612-9616. [CrossRef] [PubMed]

18. Lang, V.; Zanchin, N.I.; Lunsdorf, H.; Tuite, M.; McCarthy, J.E. Initiation factor eIF-4E of Saccharomyces cerevisiae. Distribution within the cell, binding to mRNA, and consequences of its overproduction. J. Biol. Chem. 1994, 269, 6117-6123. [CrossRef]

19. Robalino, J.; Joshi, B.; Fahrenkrug, S.C.; Jagus, R. Two zebrafish eIF4E family members are differentially expressed and functionally divergent. J. Biol. Chem. 2004, 279, 10532-10541. [CrossRef] [PubMed]

20. Matsuyama, A.; Arai, R.; Yashiroda, Y.; Shirai, A.; Kamata, A.; Sekido, S.; Kobayashi, Y.; Hashimoto, A.; Hamamoto, M.; Hiraoka, Y.; et al. ORFeome cloning and global analysis of protein localization in the fission yeast Schizosaccharomyces pombe. Nat. Biotechnol. 2006, 24, 841-847. [CrossRef] [PubMed]

21. Huh, W.K.; Falvo, J.V.; Gerke, L.C.; Carroll, A.S.; Howson, R.W.; Weissman, J.S.; O'Shea, E.K. Global analysis of protein localization in budding yeast. Nature 2003, 425, 686-691. [CrossRef]

22. Lye, C.M.; Naylor, H.W.; Sanson, B. Subcellular localisations of the CPTI collection of YFP-tagged proteins in Drosophila embryos. Development 2014, 141, 4006-4017. [CrossRef]

23. Bae, M.S.; Cho, E.J.; Choi, E.Y.; Park, O.K. Analysis of the Arabidopsis nuclear proteome and its response to cold stress. Plant J. 2003, 36, 652-663. [CrossRef] [PubMed]

24. Koroleva, O.A.; Tomlinson, M.L.; Leader, D.; Shaw, P.; Doonan, J.H. High-throughput protein localization in Arabidopsis using Agrobacterium-mediated transient expression of GFP-ORF fusions. Plant J. 2005, 41, 162-174. [CrossRef] [PubMed] 
25. Goto, C.; Hashizume, S.; Fukao, Y.; Hara-Nishimura, I.; Tamura, K. Comprehensive nuclear proteome of Arabidopsis obtained by sequential extraction. Nucleus 2019, 10, 81-92. [CrossRef]

26. Ayash, M.; Abukhalaf, M.; Thieme, D.; Proksch, C.; Heilmann, M.; Schattat, M.; Hoehenwarter, W. LC-MS Based Draft Map of the Arabidopsis thaliana Nuclear Proteome and Protein Import in Pattern Triggered Immunity. Front. Plant Sci. 2021, $12,744103$. [CrossRef]

27. Bohnsack, M.T.; Regener, K.; Schwappach, B.; Saffrich, R.; Paraskeva, E.; Hartmann, E.; Gorlich, D. Exp5 exports eEF1A via tRNA from nuclei and synergizes with oTher. transport pathways to confine translation to the cytoplasm. EMBO J. 2002, 21, 6205-6215. [CrossRef]

28. Mingot, J.M.; Kostka, S.; Kraft, R.; Hartmann, E.; Gorlich, D. Importin 13: A novel mediator of nuclear import and export. EMBO J. 2001, 20, 3685-3694. [CrossRef] [PubMed]

29. Smirnova, E.V.; Rakitina, T.V.; Bogatova, O.V.; Ivanova, D.L.; Vorobyeva, E.E.; Lipkin, A.V.; Kostanyan, I.A.; Lipkin, V.M. Novel protein haponin regulates cellular response to oxidative stress. Dokl. Biochem. Biophys. 2011, 440, 225-227. [CrossRef]

30. Sanvito, F.; Piatti, S.; Villa, A.; Bossi, M.; Lucchini, G.; Marchisio, P.C.; Biffo, S. The beta4 integrin interactor p27(BBP/eIF6) is an essential nuclear matrix protein involved in 60S ribosomal subunit assembly. J. Cell Biol. 1999, 144, 823-837. [CrossRef]

31. Dubey, A.; Copeland, P.R. The Selenocysteine-Specific Elongation Factor Contains Unique Sequences That Are Required for Both Nuclear Export and Selenocysteine Incorporation. PLoS ONE 2016, 11, e0165642. [CrossRef]

32. Wuhr, M.; Guttler, T.; Peshkin, L.; McAlister, G.C.; Sonnett, M.; Ishihara, K.; Groen, A.C.; Presler, M.; Erickson, B.K.; Mitchison, T.J.; et al. The Nuclear Proteome of a Vertebrate. Curr. Biol. 2015, 25, 2663-2671. [CrossRef]

33. Rafiee, M.-R.; Zagalak, J.A.; Sidorov, S.; Steinhauser, S.; Davey, K.; Ule, J.; Luscombe, N.M. Chromatin-contact atlas reveals disorder-mediated protein interactions and moonlighting chromatin-associated RBPs. bioRxiv 2021, 200212. [CrossRef]

34. Pendle, A.F.; Clark, G.P.; Boon, R.; Lewandowska, D.; Lam, Y.W.; Andersen, J.; Mann, M.; Lamond, A.I.; Brown, J.W.; Shaw, P.J. Proteomic analysis of the Arabidopsis nucleolus suggests novel nucleolar functions. Mol. Biol. Cell 2005, 16, 260-269. [CrossRef]

35. Lacoux, C.; Wacheul, L.; Saraf, K.; Pythoud, N.; Huvelle, E.; Figaro, S.; Graille, M.; Carapito, C.; Lafontaine, D.L.J.; HeurgueHamard, V. The catalytic activity of the translation termination factor methyltransferase Mtq2-Trm112 complex is required for large ribosomal subunit biogenesis. Nucleic Acids Res. 2020, 48, 12310-12325. [CrossRef]

36. Salsman, J.; Pinder, J.; Tse, B.; Corkery, D.; Dellaire, G. The translation initiation factor 3 subunit eIF3K interacts with PML and associates with PML nuclear bodies. Exp. Cell Res. 2013, 319, 2554-2565. [CrossRef]

37. Shen, X.; Yang, Y.; Liu, W.; Sun, M.; Jiang, J.; Zong, H.; Gu, J. Identification of the p28 subunit of eukaryotic initiation factor 3(eIF3k) as a new interaction partner of cyclin D3. FEBS Lett. 2004, 573, 139-146. [CrossRef]

38. Morris-Desbois, C.; Bochard, V.; Reynaud, C.; Jalinot, P. Interaction between the Ret finger protein and the Int-6 gene product and co-localisation into nuclear bodies. J. Cell Sci. 1999, 112 Pt 19, 3331-3342. [CrossRef]

39. Lai, H.K.; Borden, K.L. The promyelocytic leukemia (PML) protein suppresses cyclin D1 protein production by altering the nuclear cytoplasmic distribution of cyclin D1 mRNA. Oncogene 2000, 19, 1623-1634. [CrossRef]

40. Saitoh, N.; Spahr, C.S.; Patterson, S.D.; Bubulya, P.; Neuwald, A.F.; Spector, D.L. Proteomic analysis of interchromatin granule clusters. Mol. Biol. Cell 2004, 15, 3876-3890. [CrossRef]

41. Gassmann, R.; Henzing, A.J.; Earnshaw, W.C. Novel components of human mitotic chromosomes identified by proteomic analysis of the chromosome scaffold fraction. Chromosoma 2005, 113, 385-397. [CrossRef]

42. Takata, H.; Nishijima, H.; Ogura, S.; Sakaguchi, T.; Bubulya, P.A.; Mochizuki, T.; Shibahara, K. Proteome analysis of human nuclear insoluble fractions. Genes Cells 2009, 14, 975-990. [CrossRef]

43. Piazzi, M.; Blalock, W.L.; Bavelloni, A.; Faenza, I.; D’Angelo, A.; Maraldi, N.M.; Cocco, L. Phosphoinositide-specific phospholipase $\mathrm{C}$ beta $1 \mathrm{~b}$ (PI-PLCbeta1b) interactome: Affinity purification-mass spectrometry analysis of PI-PLCbeta1b with nuclear protein. Mol. Cell Proteom. 2013, 12, 2220-2235. [CrossRef]

44. Guruharsha, K.G.; Rual, J.F.; Zhai, B.; Mintseris, J.; Vaidya, P.; Vaidya, N.; Beekman, C.; Wong, C.; Rhee, D.Y.; Cenaj, O.; et al. A protein complex network of Drosophila melanogaster. Cell 2011, 147, 690-703. [CrossRef]

45. Sesen, J.; Casaos, J.; Scotland, S.J.; Seva, C.; Eisinger-Mathason, T.S.; Skuli, N. The Bad, the Good and eIF3e/INT6. Front. BioSci. (Landmark Ed) 2017, 22, 1-20. [CrossRef]

46. Hoareau Alves, K.; Bochard, V.; Rety, S.; Jalinot, P. Association of the mammalian proto-oncoprotein Int- 6 with the three protein complexes eIF3, COP9 signalosome and $26 \mathrm{~S}$ proteasome. FEBS Lett. 2002, 527, 15-21. [CrossRef]

47. Yen, H.C.; Gordon, C.; Chang, E.C. Schizosaccharomyces pombe Int6 and Ras homologs regulate cell division and mitotic fidelity via the proteasome. Cell 2003, 112, 207-217. [CrossRef]

48. Sha, Z.; Brill, L.M.; Cabrera, R.; Kleifeld, O.; Scheliga, J.S.; Glickman, M.H.; Chang, E.C.; Wolf, D.A. The eIF3 interactome reveals the translasome, a supercomplex linking protein synthesis and degradation machineries. Mol. Cell 2009, 36, 141-152. [CrossRef]

49. Yahalom, A.; Kim, T.H.; Winter, E.; Karniol, B.; von Arnim, A.G.; Chamovitz, D.A. Arabidopsis eIF3e (INT-6) associates with both eIF3c and the COP9 signalosome subunit CSN7. J. Biol. Chem. 2001, 276, 334-340. [CrossRef]

50. Kimball, S.R.; Horetsky, R.L.; Ron, D.; Jefferson, L.S.; Harding, H.P. Mammalian stress granules represent sites of accumulation of stalled translation initiation complexes. Am. J. Physiol. Cell Physiol. 2003, 284, C273-C284. [CrossRef]

51. Goldstein, E.N.; Owen, C.R.; White, B.C.; Rafols, J.A. Ultrastructural localization of phosphorylated eIF2alpha [eIF2alpha(P)] in rat dorsal hippocampus during reperfusion. Acta Neuropathol. 1999, 98, 493-505. [CrossRef] 
52. Lobo, M.V.; Alonso, F.J.; Rodriguez, S.; Alcazar, A.; Martin, E.; Munoz, F.; Santander, R.G.; Salinas, M.; Fando, J.L. Localization of eukaryotic initiation factor 2 in neuron primary cultuRes. and established cell lines. Histochem. J. 1997, 29, 453-468. [CrossRef]

53. DeGracia, D.J.; Sullivan, J.M.; Neumar, R.W.; Alousi, S.S.; Hikade, K.R.; Pittman, J.E.; White, B.C.; Rafols, J.A.; Krause, G.S. Effect of brain ischemia and reperfusion on the localization of phosphorylated eukaryotic initiation factor 2 alpha. J. Cereb. Blood Flow Metab. 1997, 17, 1291-1302. [CrossRef]

54. Beausoleil, S.A.; Jedrychowski, M.; Schwartz, D.; Elias, J.E.; Villen, J.; Li, J.; Cohn, M.A.; Cantley, L.C.; Gygi, S.P. Large-scale characterization of HeLa cell nuclear phosphoproteins. Proc. Natl. Acad. Sci. USA 2004, 101, 12130-12135. [CrossRef]

55. Turpaev, K.T. Translation Factor eIF5A, Modification with Hypusine and Role in Regulation of Gene Expression. eIF5A as a Target for Pharmacological Interventions. Biochemistry 2018, 83, 863-873. [CrossRef]

56. Lee, S.B.; Park, J.H.; Kaevel, J.; Sramkova, M.; Weigert, R.; Park, M.H. The effect of hypusine modification on the intracellular localization of eIF5A. Biochem. Biophys. Res. Commun. 2009, 383, 497-502. [CrossRef]

57. Aksu, M.; Trakhanov, S.; Gorlich, D. Structure of the exportin Xpo4 in complex with RanGTP and the hypusine-containing translation factor eIF5A. Nat. Commun. 2016, 7, 11952. [CrossRef]

58. Ren, B.; Chen, Q.; Hong, S.; Zhao, W.; Feng, J.; Feng, H.; Zuo, J. The Arabidopsis eukaryotic translation initiation factor eIF5A-2 regulates root protoxylem development by modulating cytokinin signaling. Plant Cell 2013, 25, 3841-3857. [CrossRef]

59. Hopkins, M.T.; Lampi, Y.; Wang, T.W.; Liu, Z.; Thompson, J.E. Eukaryotic translation initiation factor 5A is involved in pathogeninduced cell death and development of disease symptoms in Arabidopsis. Plant Physiol. 2008, 148, 479-489. [CrossRef]

60. Lebska, M.; Ciesielski, A.; Szymona, L.; Godecka, L.; Lewandowska-Gnatowska, E.; Szczegielniak, J.; Muszynska, G. Phosphorylation of maize eukaryotic translation initiation factor 5A (eIF5A) by casein kinase 2: Identification of phosphorylated residue and influence on intracellular localization of eIF5A. J. Biol. Chem. 2010, 285, 6217-6226. [CrossRef]

61. Lewandowska-Gnatowska, E.; Szymona, L.; Lebska, M.; Szczegielniak, J.; Muszynska, G. Phosphorylation of maize eukaryotic translation initiation factor on Ser2 by catalytic subunit CK2. Mol. Cell Biochem. 2011, 356, 241-244. [CrossRef]

62. Jao, D.L.; Yu Chen, K. Subcellular localization of the hypusine-containing eukaryotic initiation factor 5A by immunofluorescent staining and green fluorescent protein tagging. J. Cell Biochem. 2002, 86, 590-600. [CrossRef]

63. Parreiras, E.S.L.T.; Gomes, M.D.; Oliveira, E.B.; Costa-Neto, C.M. The N-terminal region of eukaryotic translation initiation factor 5A signals to nuclear localization of the protein. Biochem. Biophys. Res. Commun. 2007, 362, 393-398. [CrossRef]

64. Wu, G.Q.; Xu, Y.M.; Lau, A.T.Y. Recent insights into eukaryotic translation initiation factors 5A1 and 5A2 and their roles in human health and disease. Cancer Cell Int. 2020, 20, 142. [CrossRef]

65. Dostie, J.; Ferraiuolo, M.; Pause, A.; Adam, S.A.; Sonenberg, N. A novel shuttling protein, 4E-T, mediates the nuclear import of the mRNA 5' cap-binding protein, eIF4E. EMBO J. 2000, 19, 3142-3156. [CrossRef]

66. Kamenska, A.; Lu, W.T.; Kubacka, D.; Broomhead, H.; Minshall, N.; Bushell, M.; Standart, N. Human 4E-T represses translation of bound mRNAs and enhances microRNA-mediated silencing. Nucleic Acids Res. 2014, 42, 3298-3313. [CrossRef]

67. Marnef, A.; Weil, D.; Standart, N. RNA-related nuclear functions of human Pat1b, the P-body mRNA decay factor. Mol. Biol. Cell 2012, 23, 213-224. [CrossRef]

68. Huang, J.H.; Ku, W.C.; Chen, Y.C.; Chang, Y.L.; Chu, C.Y. Dual mechanisms regulate the nucleocytoplasmic localization of human DDX6. Sci. Rep. 2017, 7, 42853. [CrossRef]

69. Zappavigna, V.; Piccioni, F.; Villaescusa, J.C.; Verrotti, A.C. Cup is a nucleocytoplasmic shuttling protein that interacts with the eukaryotic translation initiation factor 4E to modulate Drosophila ovary development. Proc. Natl. Acad. Sci. USA 2004, 101, 14800-14805. [CrossRef]

70. Desbois, C.; Rousset, R.; Bantignies, F.; Jalinot, P. Exclusion of Int-6 from PML nuclear bodies by binding to the HTLV-I Tax oncoprotein. Science 1996, 273, 951-953. [CrossRef]

71. Toro-Ascuy, D.; Rojas-Araya, B.; Garcia-de-Gracia, F.; Rojas-Fuentes, C.; Pereira-Montecinos, C.; Gaete-Argel, A.; ValienteEcheverria, F.; Ohlmann, T.; Soto-Rifo, R. A Rev-CBP80-eIF4AI complex drives Gag synthesis from the HIV-1 unspliced mRNA. Nucleic Acids Res. 2018, 46, 11539-11552. [CrossRef]

72. Etchison, D.; Etchison, J.R. Monoclonal antibody-aided characterization of cellular p220 in uninfected and poliovirus-infected HeLa cells: Subcellular distribution and identification of conformers. J. Virol. 1987, 61, 2702-2710. [CrossRef]

73. Cakmakci, N.G.; Lerner, R.S.; Wagner, E.J.; Zheng, L.; Marzluff, W.F. SLIP1, a factor required for activation of histone mRNA translation by the stem-loop binding protein. Mol. Cell Biol. 2008, 28, 1182-1194. [CrossRef] [PubMed]

74. Yamaji, M.; Tanaka, T.; Shigeta, M.; Chuma, S.; Saga, Y.; Saitou, M. Functional reconstruction of NANOS3 expression in the germ cell lineage by a novel transgenic reporter reveals distinct subcellular localizations of NANOS3. Reproduction 2010, 139, 381-393. [CrossRef]

75. Julaton, V.T.; Reijo Pera, R.A. NANOS3 function in human germ cell development. Hum. Mol. Genet. 2011, 20 , 2238-2250. [CrossRef] [PubMed]

76. Zhou, X.; Zhong, Y.; Molinar-Inglis, O.; Kunkel, M.T.; Chen, M.; Sun, T.; Zhang, J.; Shyy, J.Y.; Trejo, J.; Newton, A.C.; et al. Location-specific inhibition of Akt reveals regulation of mTORC1 activity in the nucleus. Nat. Commun. 2020, 11, 6088. [CrossRef]

77. Schule, M.; Butto, T.; Dewi, S.; Schlichtholz, L.; Strand, S.; Gerber, S.; Endres, K.; Schweiger, S.; Winter, J. mTOR Driven Gene Transcription Is Required for Cholesterol Production in Neurons of the Developing Cerebral Cortex. Int. J. Mol. Sci. 2021, 22, 6034. [CrossRef] 
78. Blalock, W.L.; Bavelloni, A.; Piazzi, M.; Tagliavini, F.; Faenza, I.; Martelli, A.M.; Follo, M.Y.; Cocco, L. Multiple forms of PKR present in the nuclei of acute leukemia cells represent an active kinase that is responsive to stress. Leukemia 2011, 25, 236-245. [CrossRef]

79. Bernstein, K.A.; Gallagher, J.E.; Mitchell, B.M.; Granneman, S.; Baserga, S.J. The small-subunit processome is a ribosome assembly intermediate. Eukaryot Cell 2004, 3, 1619-1626. [CrossRef]

80. Kressler, D.; Bange, G.; Ogawa, Y.; Stjepanovic, G.; Bradatsch, B.; Pratte, D.; Amlacher, S.; Strauss, D.; Yoneda, Y.; Katahira, J.; et al Synchronizing nuclear import of ribosomal proteins with ribosome assembly. Science 2012, 338, 666-671. [CrossRef]

81. Robledo, S.; Idol, R.A.; Crimmins, D.L.; Ladenson, J.H.; Mason, P.J.; Bessler, M. The role of human ribosomal proteins in the maturation of rRNA and ribosome production. RNA 2008, 14, 1918-1929. [CrossRef]

82. Sekiguchi, T.; Hayano, T.; Yanagida, M.; Takahashi, N.; Nishimoto, T. NOP132 is required for proper nucleolus localization of DEAD-box RNA helicase DDX47. Nucleic Acids Res. 2006, 34, 4593-4608. [CrossRef]

83. Fong, K.W.; Li, Y.; Wang, W.; Ma, W.; Li, K.; Qi, R.Z.; Liu, D.; Songyang, Z.; Chen, J. Whole-genome screening identifies proteins localized to distinct nuclear bodies. J. Cell Biol. 2013, 203, 149-164. [CrossRef] [PubMed]

84. Nicolas, E.; Parisot, P.; Pinto-Monteiro, C.; de Walque, R.; De Vleeschouwer, C.; Lafontaine, D.L. Involvement of human ribosomal proteins in nucleolar structure and p53-dependent nucleolar stress. Nat. Commun. 2016, 7, 11390. [CrossRef]

85. Melnikov, S.; Ben-Shem, A.; Yusupova, G.; Yusupov, M. Insights into the origin of the nuclear localization signals in conserved ribosomal proteins. Nat. Commun. 2015, 6, 8382. [CrossRef] [PubMed]

86. Stelter, P.; Huber, F.M.; Kunze, R.; Flemming, D.; Hoelz, A.; Hurt, E. Coordinated Ribosomal L4 Protein Assembly into the Pre-Ribosome Is Regulated by Its Eukaryote-Specific Extension. Mol. Cell 2015, 58, 854-862. [CrossRef]

87. Claussen, M.; Rudt, F.; Pieler, T. Functional modules in ribosomal protein L5 for ribonucleoprotein complex formation and nucleocytoplasmic transport. J. Biol. Chem. 1999, 274, 33951-33958. [CrossRef] [PubMed]

88. Nagahama, M.; Hara, Y.; Seki, A.; Yamazoe, T.; Kawate, Y.; Shinohara, T.; Hatsuzawa, K.; Tani, K.; Tagaya, M. NVL2 is a nucleolar AAA-ATPase that interacts with ribosomal protein L5 through its nucleolar localization sequence. Mol. Biol. Cell 2004, 15, 5712-5723. [CrossRef] [PubMed]

89. Plafker, S.M.; Macara, I.G. Ribosomal protein L12 uses a distinct nuclear import pathway mediated by importin 11. Mol. Cell Biol. 2002, 22, 1266-1275. [CrossRef] [PubMed]

90. Jakel, S.; Gorlich, D. Importin beta, transportin, RanBP5 and RanBP7 mediate nuclear import of ribosomal proteins in mammalian cells. EMBO J. 1998, 17, 4491-4502. [CrossRef]

91. Mitterer, V.; Gantenbein, N.; Birner-Gruenberger, R.; Murat, G.; Bergler, H.; Kressler, D.; Pertschy, B. Nuclear import of dimerized ribosomal protein Rps3 in complex with its chaperone Yar1. Sci. Rep. 2016, 6, 36714. [CrossRef]

92. Andersen, J.S.; Lam, Y.W.; Leung, A.K.; Ong, S.E.; Lyon, C.E.; Lamond, A.I.; Mann, M. Nucleolar proteome dynamics. Nature 2005, 433, 77-83. [CrossRef]

93. Kazyken, D.; Kaz, Y.; Kiyan, V.; Zhylkibayev, A.A.; Chen, C.H.; Agarwal, N.K.; dos Sarbassov, D. The nuclear import of ribosomal proteins is regulated by mTOR. Oncotarget 2014, 5, 9577-9593. [CrossRef]

94. Falcone Ferreyra, M.L.; Casadevall, R.; Luciani, M.D.; Pezza, A.; Casati, P. New evidence for differential roles of 110 ribosomal proteins from Arabidopsis. Plant Physiol. 2013, 163, 378-391. [CrossRef] [PubMed]

95. Ren, J.; Wang, Y.; Liang, Y.; Zhang, Y.; Bao, S.; Xu, Z. Methylation of ribosomal protein S10 by protein-arginine methyltransferase 5 regulates ribosome biogenesis. J. Biol. Chem. 2010, 285, 12695-12705. [CrossRef]

96. Shin, H.S.; Jang, C.Y.; Kim, H.D.; Kim, T.S.; Kim, S.; Kim, J. Arginine methylation of ribosomal protein S3 affects ribosome assembly. Biochem. Biophys. Res. Commun. 2009, 385, 273-278. [CrossRef] [PubMed]

97. Malecki, J.M.; Odonohue, M.F.; Kim, Y.; Jakobsson, M.E.; Gessa, L.; Pinto, R.; Wu, J.; Davydova, E.; Moen, A.; Olsen, J.V.; et al Human METTL18 is a histidine-specific methyltransferase that targets RPL3 and affects ribosome biogenesis and function. Nucleic Acids Res. 2021, 49, 3185-3203. [CrossRef] [PubMed]

98. Kearse, M.G.; Ireland, J.A.; Prem, S.M.; Chen, A.S.; Ware, V.C. RpL22e, but not RpL22e-like-PA, is SUMOylated and localizes to the nucleoplasm of Drosophila meiotic spermatocytes. Nucleus 2013, 4, 241-258. [CrossRef]

99. Fok, V.; Mitton-Fry, R.M.; Grech, A.; Steitz, J.A. Multiple domains of EBER 1, an Epstein-Barr virus noncoding RNA, recruit human ribosomal protein L22. RNA 2006, 12, 872-882. [CrossRef]

100. Toczyski, D.P.; Matera, A.G.; Ward, D.C.; Steitz, J.A. The Epstein-Barr virus (EBV) small RNA EBER1 binds and relocalizes ribosomal protein L22 in EBV-infected human B lymphocytes. Proc. Natl. Acad. Sci. USA 1994, 91, 3463-3467. [CrossRef]

101. Rajamaki, M.L.; Sikorskaite-Gudziuniene, S.; Sarmah, N.; Varjosalo, M.; Valkonen, J.P.T. Nuclear proteome of virus-infected and healthy potato leaves. BMC Plant Biol. 2020, 20, 355. [CrossRef]

102. Li, Y.; Dong, W.; Shi, Y.; Deng, F.; Chen, X.; Wan, C.; Zhou, M.; Zhao, L.; Fu, Z.F.; Peng, G. Rabies virus phosphoprotein interacts with ribosomal protein L9 and affects rabies virus replication. Virology 2016, 488, 216-224. [CrossRef]

103. Lindstrom, M.S.; Zhang, Y. Ribosomal protein S9 is a novel B23/NPM-binding protein required for normal cell proliferation. J. Biol. Chem. 2008, 283, 15568-15576. [CrossRef]

104. Lindstrom, M.S. Elucidation of motifs in ribosomal protein S9 that mediate its nucleolar localization and binding to NPM1/nucleophosmin. PLoS ONE 2012, 7, e52476. [CrossRef] [PubMed]

105. Ba, Q.; Li, X.; Huang, C.; Li, J.; Fu, Y.; Chen, P.; Duan, J.; Hao, M.; Zhang, Y.; Li, J.; et al. BCCIPbeta modulates the ribosomal and extraribosomal function of S7 through a direct interaction. J. Mol. Cell Biol. 2017, 9, 209-219. [CrossRef] 
106. Wyler, E.; Wandrey, F.; Badertscher, L.; Montellese, C.; Alper, D.; Kutay, U. The beta-isoform of the BRCA2 and CDKN1A(p21)interacting protein (BCCIP) stabilizes nuclear RPL23/uL14. FEBS Lett. 2014, 588, 3685-3691. [CrossRef] [PubMed]

107. Hamaguchi, N.; Ohdaira, T.; Shinohara, A.; Iwamatsu, A.; Ihara, S.; Fukui, Y. Identification of ribosomal protein S3a as a candidate for a novel PI 3-kinase target in the nucleus. Cytotechnology 2002, 40, 85-92. [CrossRef]

108. Tsubota, S.I.; Phillips, A.C. Drosophila Enhancer of Rudimentary Homolog, ERH, Is a Binding Partner of RPS3, RPL19, and DDIT4, Suggesting a Mechanism for the Nuclear Localization of ERH. Mol. Biol. Int. 2016, 2016, 8371819. [CrossRef] [PubMed]

109. Beyer, A.R.; Bann, D.V.; Rice, B.; Pultz, I.S.; Kane, M.; Goff, S.P.; Golovkina, T.V.; Parent, L.J. Nucleolar trafficking of the mouse mammary tumor virus gag protein induced by interaction with ribosomal protein L9. J. Virol. 2013, 87, 1069-1082. [CrossRef]

110. Bernardi, R.; Scaglioni, P.P.; Bergmann, S.; Horn, H.F.; Vousden, K.H.; Pandolfi, P.P. PML regulates p53 stability by sequestering Mdm2 to the nucleolus. Nat. Cell Biol. 2004, 6, 665-672. [CrossRef]

111. Chen, W.; Dittmer, D.P. Ribosomal protein S6 interacts with the latency-associated nuclear antigen of Kaposi's sarcoma-associated herpesvirus. J. Virol. 2011, 85, 9495-9505. [CrossRef]

112. Robles, M.S.; Boyault, C.; Knutti, D.; Padmanabhan, K.; Weitz, C.J. Identification of RACK1 and protein kinase Calpha as integral components of the mammalian circadian clock. Science 2010, 327, 463-466. [CrossRef]

113. Guo, J.; Wang, S.; Valerius, O.; Hall, H.; Zeng, Q.; Li, J.F.; Weston, D.J.; Ellis, B.E.; Chen, J.G. Involvement of Arabidopsis RACK1 in protein translation and its regulation by abscisic acid. Plant Physiol. 2011, 155, 370-383. [CrossRef]

114. Yadavilli, S.; Hegde, V.; Deutsch, W.A. Translocation of human ribosomal protein S3 to sites of DNA damage is dependant on ERK-mediated phosphorylation following genotoxic stress. DNA Repair 2007, 6, 1453-1462. [CrossRef] [PubMed]

115. Yoon, I.S.; Chung, J.H.; Hahm, S.H.; Park, M.J.; Lee, Y.R.; Ko, S.I.; Kang, L.W.; Kim, T.S.; Kim, J.; Han, Y.S. Ribosomal protein S3 is phosphorylated by Cdk1/cdc2 during G2/M phase. BMB Rep. 2011, 44, 529-534. [CrossRef] [PubMed]

116. Kim, T.S.; Kim, H.D.; Kim, J. PKCdelta-dependent functional switch of rpS3 between translation and DNA repair. Biochim. Biophys. Acta 2009, 1793, 395-405. [CrossRef]

117. Kim, H.D.; Lee, J.Y.; Kim, J. Erk phosphorylates threonine 42 residue of ribosomal protein S3. Biochem. Biophys. Res. Commun. 2005, 333, 110-115. [CrossRef]

118. Kim, T.S.; Kim, H.D.; Shin, H.S.; Kim, J. Phosphorylation status of nuclear ribosomal protein S3 is reciprocally regulated by protein kinase C\{delta\} and protein phosphatase 2A. J. Biol. Chem. 2009, 284, 21201-21208. [CrossRef]

119. Kim, J.; Chubatsu, L.S.; Admon, A.; Stahl, J.; Fellous, R.; Linn, S. Implication of mammalian ribosomal protein S3 in the processing of DNA damage. J. Biol. Chem. 1995, 270, 13620-13629. [CrossRef] [PubMed]

120. Kim, S.H.; Lee, J.Y.; Kim, J. Characterization of a wide range base-damage-endonuclease activity of mammalian rpS3. Biochem. Biophys. Res. Commun. 2005, 328, 962-967. [CrossRef]

121. Wilson, D.M., 3rd; Deutsch, W.A.; Kelley, M.R. Drosophila ribosomal protein S3 contains an activity that cleaves DNA at apurinic/apyrimidinic sites. J. Biol. Chem. 1994, 269, 25359-25364. [CrossRef]

122. Grosheva, A.S.; Zharkov, D.O.; Stahl, J.; Gopanenko, A.V.; Tupikin, A.E.; Kabilov, M.R.; Graifer, D.M.; Karpova, G.G. Recognition but no repair of abasic site in single-stranded DNA by human ribosomal uS3 protein residing within intact 40S subunit. Nucleic Acids Res. 2017, 45, 3833-3843. [CrossRef] [PubMed]

123. Hegde, V.; Wang, M.; Deutsch, W.A. Human ribosomal protein S3 interacts with DNA base excision repair proteins hAPE/Ref-1 and hOGG1. Biochemistry 2004, 43, 14211-14217. [CrossRef]

124. Ko, S.I.; Park, J.H.; Park, M.J.; Kim, J.; Kang, L.W.; Han, Y.S. Human ribosomal protein S3 (hRpS3) interacts with uracil-DNA glycosylase (hUNG) and stimulates its glycosylase activity. Mutat. Res. 2008, 648, 54-64. [CrossRef] [PubMed]

125. Park, Y.J.; Kim, S.H.; Kim, T.S.; Lee, S.M.; Cho, B.S.; Seo, C.I.; Kim, H.D.; Kim, J. Ribosomal protein S3 associates with the TFIIH complex and positively regulates nucleotide excision repair. Cell Mol. Life Sci. 2021, 78, 3591-3606. [CrossRef]

126. Patil, A.V.; Hsieh, T.S. Ribosomal Protein S3 Negatively Regulates Unwinding Activity of RecQ-like Helicase 4 through Their Physical Interaction. J. Biol. Chem. 2017, 292, 4313-4325. [CrossRef]

127. Lee, S.B.; Kwon, I.S.; Park, J.; Lee, K.H.; Ahn, Y.; Lee, C.; Kim, J.; Choi, S.Y.; Cho, S.W.; Ahn, J.Y. Ribosomal protein S3, a new substrate of Akt, serves as a signal mediator between neuronal apoptosis and DNA repair. J. Biol. Chem. 2010, 285, 29457-29468. [CrossRef] [PubMed]

128. Jang, C.Y.; Lee, J.Y.; Kim, J. RpS3, a DNA repair endonuclease and ribosomal protein, is involved in apoptosis. FEBS Lett. 2004, 560, 81-85. [CrossRef]

129. Guerra-Rebollo, M.; Mateo, F.; Franke, K.; Huen, M.S.; Lopitz-Otsoa, F.; Rodriguez, M.S.; Plans, V.; Thomson, T.M. Nucleolar exit of RNF8 and BRCA1 in response to DNA damage. Exp. Cell Res. 2012, 318, 2365-2376. [CrossRef]

130. Yang, C.; Zang, W.; Ji, Y.; Li, T.; Yang, Y.; Zheng, X. Ribosomal protein L6 (RPL6) is recruited to DNA damage sites in a poly(ADP-ribose) polymerase-dependent manner and regulates the DNA damage response. J. Biol. Chem. 2019, 294, 2827-2838. [CrossRef]

131. Sun, S.; He, H.; Ma, Y.; Xu, J.; Chen, G.; Sun, Y.; Xiong, X. Inactivation of ribosomal protein S27-like impairs DNA interstrand cross-link repair by destabilization of FANCD2 and FANCI. Cell Death Dis. 2020, 11, 852. [CrossRef] [PubMed]

132. Vascotto, C.; Fantini, D.; Romanello, M.; Cesaratto, L.; Deganuto, M.; Leonardi, A.; Radicella, J.P.; Kelley, M.R.; D’Ambrosio, C.; Scaloni, A.; et al. APE1/Ref-1 interacts with NPM1 within nucleoli and plays a role in the rRNA quality control process. Mol. Cell Biol. 2009, 29, 1834-1854. [CrossRef] 
133. Grabowski, D.T.; Deutsch, W.A.; Derda, D.; Kelley, M.R. Drosophila AP3, a presumptive DNA repair protein, is homologous to human ribosomal associated protein P0. Nucleic Acids Res. 1991, 19, 4297. [CrossRef] [PubMed]

134. Molavi, G.; Samadi, N.; Hosseingholi, E.Z. The roles of moonlight ribosomal proteins in the development of human cancers. J. Cell Physiol. 2019, 234, 8327-8341. [CrossRef] [PubMed]

135. Esposito, D.; Crescenzi, E.; Sagar, V.; Loreni, F.; Russo, A.; Russo, G. Human rpL3 plays a crucial role in cell response to nucleolar stress induced by 5-FU and L-OHP. Oncotarget 2014, 5, 11737-11751. [CrossRef]

136. Ting, N.S.; Kao, P.N.; Chan, D.W.; Lintott, L.G.; Lees-Miller, S.P. DNA-dependent protein kinase interacts with antigen receptor response element binding proteins NF90 and NF45. J. Biol. Chem. 1998, 273, 2136-2145. [CrossRef]

137. Morris, C.; Tomimatsu, N.; Richard, D.J.; Cluet, D.; Burma, S.; Khanna, K.K.; Jalinot, P. INT6/EIF3E interacts with ATM and is required for proper execution of the DNA damage response in human cells. Cancer Res. 2012, 72, 2006-2016. [CrossRef]

138. Morris, C.; Tomimatsu, N.; Burma, S.; Jalinot, P. INT6/EIF3E Controls the RNF8-Dependent Ubiquitylation Pathway and Facilitates DNA Double-Strand Break Repair in Human Cells. Cancer Res. 2016, 76, 6054-6065. [CrossRef]

139. Chung, D.; Dellaire, G. The Role of the COP9 Signalosome and Neddylation in DNA Damage Signaling and Repair. Biomolecules 2015, 5, 2388-2416. [CrossRef]

140. Abdulkina, L.R.; Kobayashi, C.; Lovell, J.T.; Chastukhina, I.B.; Aklilu, B.B.; Agabekian, I.A.; Suescun, A.V.; Valeeva, L.R.; Nyamsuren, C.; Aglyamova, G.V.; et al. Components of the ribosome biogenesis pathway underlie establishment of telomere length set poInt. in Arabidopsis. Nat. Commun. 2019, 10, 5479. [CrossRef]

141. Buchsbaum, S.; Morris, C.; Bochard, V.; Jalinot, P. Human INT6 interacts with MCM7 and regulates its stability during S phase of the cell cycle. Oncogene 2007, 26, 5132-5144. [CrossRef]

142. Shen, C.L.; Liu, C.D.; You, R.I.; Ching, Y.H.; Liang, J.; Ke, L.; Chen, Y.L.; Chen, H.C.; Hsu, H.J.; Liou, J.W.; et al. Ribosome Protein L4 is essential for Epstein-Barr Virus Nuclear Antigen 1 function. Proc. Natl. Acad. Sci. USA 2016, 113, 2229-2234. [CrossRef]

143. Park, B.J.; Kang, J.W.; Lee, S.W.; Choi, S.J.; Shin, Y.K.; Ahn, Y.H.; Choi, Y.H.; Choi, D.; Lee, K.S.; Kim, S. The haploinsufficient tumor suppressor p18 upregulates p53 via interactions with ATM/ATR. Cell 2005, 120, 209-221. [CrossRef] [PubMed]

144. Kim, S.M.; Jeon, Y.; Kim, D.; Jang, H.; Bae, J.S.; Park, M.K.; Kim, H.; Kim, S.; Lee, H. AIMP3 depletion causes genome instability and loss of stemness in mouse embryonic stem cells. Cell Death Dis. 2018, 9, 972. [CrossRef] [PubMed]

145. Kim, D.; Kim, S.; Oh, Y.; Park, S.; Jeon, Y.; Kim, H.; Lee, H.; Kim, S. AIMP3 Deletion Induces Acute Radiation Syndrome-like Phenotype in Mice. Sci. Rep. 2018, 8, 15025. [CrossRef]

146. Han, J.M.; Park, B.J.; Park, S.G.; Oh, Y.S.; Choi, S.J.; Lee, S.W.; Hwang, S.K.; Chang, S.H.; Cho, M.H.; Kim, S. AIMP2/p38, the scaffold for the multi-tRNA synthetase complex, responds to genotoxic stresses via p53. Proc. Natl. Acad. Sci. USA 2008, 105, 11206-11211. [CrossRef]

147. Kim, D.G.; Lee, J.Y.; Lee, J.H.; Cho, H.Y.; Kang, B.S.; Jang, S.Y.; Kim, M.H.; Guo, M.; Han, J.M.; Kim, S.J.; et al. Oncogenic Mutation of AIMP2/p38 Inhibits Its Tumor-Suppressive Interaction with Smurf2. Cancer Res. 2016, 76, 3422-3436. [CrossRef]

148. Yao, Q.; Liu, B.Q.; Li, H.; McGarrigle, D.; Xing, B.W.; Zhou, M.T.; Wang, Z.; Zhang, J.J.; Huang, X.Y.; Guo, L. C-terminal Src kinase (Csk)-mediated phosphorylation of eukaryotic elongation factor 2 (eEF2) promotes proteolytic cleavage and nuclear translocation of eEF2. J. Biol. Chem. 2014, 289, 12666-12678. [CrossRef] [PubMed]

149. Rugjee, K.N.; Roy Chaudhury, S.; Al-Jubran, K.; Ramanathan, P.; Matina, T.; Wen, J.; Brogna, S. Fluorescent protein tagging confirms the presence of ribosomal proteins at Drosophila polytene chromosomes. Peer] 2013, 12, e15. [CrossRef]

150. Brogna, S.; Sato, T.A.; Rosbash, M. Ribosome components are associated with sites of transcription. Mol. Cell 2002, 10, 93-104. [CrossRef]

151. De, S.; Varsally, W.; Falciani, F.; Brogna, S. Ribosomal proteins' association with transcription sites peaks at tRNA genes in Schizosaccharomyces pombe. RNA 2011, 17, 1713-1726. [CrossRef]

152. Schroder, P.A.; Moore, M.J. Association of ribosomal proteins with nascent transcripts in S. cerevisiae. RNA 2005, 11, 1521-1529. [CrossRef]

153. Tasheva, E.S.; Roufa, D.J. Regulation of human RPS14 transcription by intronic antisense RNAs and ribosomal protein S14. Genes Dev. 1995, 9, 304-316. [CrossRef] [PubMed]

154. Tu, W.Y.; Huang, Y.C.; Liu, L.F.; Chang, L.H.; Tam, M.F. Rpl12p affects the transcription of the PHO pathway high-affinity inorganic phosphate transporters and repressible phosphatases. Yeast 2011, 28, 481-493. [CrossRef]

155. Ni, J.Q.; Liu, L.P.; Hess, D.; Rietdorf, J.; Sun, F.L. Drosophila ribosomal proteins are associated with linker histone H1 and suppress gene transcription. Genes Dev. 2006, 20, 1959-1973. [CrossRef]

156. Hollmuller, E.; Greiner, K.; Kienle, S.M.; Scheffner, M.; Marx, A.; Stengel, F. Interactome of Site-Specifically Acetylated Linker Histone H1. J. Proteome Res. 2021, 20, 4443-4451. [CrossRef] [PubMed]

157. Kalashnikova, A.A.; Winkler, D.D.; McBryant, S.J.; Henderson, R.K.; Herman, J.A.; DeLuca, J.G.; Luger, K.; Prenni, J.E.; Hansen, J.C. Linker histone H1.0 interacts with an extensive network of proteins found in the nucleolus. Nucleic Acids Res. 2013, 41, 4026-4035. [CrossRef]

158. Swenson, J.M.; Colmenares, S.U.; Strom, A.R.; Costes, S.V.; Karpen, G.H. The composition and organization of Drosophila heterochromatin are heterogeneous and dynamic. Elife 2016, 5, e16096. [CrossRef] [PubMed]

159. Abel, J.; Eskeland, R.; Raffa, G.D.; Kremmer, E.; Imhof, A. Drosophila HP1c is regulated by an auto-regulatory feedback loop through its binding partner Woc. PLoS ONE 2009, 4, e5089. [CrossRef] 
160. De Mateo, S.; Castillo, J.; Estanyol, J.M.; Ballesca, J.L.; Oliva, R. Proteomic characterization of the human sperm nucleus. Proteomics 2011, 11, 2714-2726. [CrossRef]

161. Dieci, G.; Ruotolo, R.; Braglia, P.; Carles, C.; Carpentieri, A.; Amoresano, A.; Ottonello, S. Positive modulation of RNA polymerase III transcription by ribosomal proteins. Biochem. Biophys. Res. Commun. 2009, 379, 489-493. [CrossRef]

162. Dai, M.S.; Sun, X.X.; Lu, H. Ribosomal protein L11 associates with c-Myc at $5 \mathrm{~S}$ rRNA and tRNA genes and regulates their expression. J. Biol. Chem. 2010, 285, 12587-12594. [CrossRef]

163. Hermann-Le Denmat, S.; Sipiczki, M.; Thuriaux, P. Suppression of yeast RNA polymerase III mutations by the URP2 gene encoding a protein homologous to the mammalian ribosomal protein S20. J. Mol. Biol. 1994, 240, 1-7. [CrossRef] [PubMed]

164. Dai, M.S.; Arnold, H.; Sun, X.X.; Sears, R.; Lu, H. Inhibition of c-Myc activity by ribosomal protein L11. EMBO J. 2007, 26, 3332-3345. [CrossRef] [PubMed]

165. Zhou, X.; Hao, Q.; Liao, J.M.; Liao, P.; Lu, H. Ribosomal protein S14 negatively regulates c-Myc activity. J. Biol. Chem. 2013, 288, 21793-21801. [CrossRef] [PubMed]

166. Russo, A.; Russo, G. Ribosomal Proteins Control or Bypass p53 during Nucleolar Stress. Int. J. Mol. Sci. 2017, 18, 140. [CrossRef] [PubMed]

167. Cui, K.; Coutts, M.; Stahl, J.; Sytkowski, A.J. Novel interaction between the transcription factor CHOP (GADD153) and the ribosomal protein FTE/S3a modulates erythropoiesis. J. Biol. Chem. 2000, 275, 7591-7596. [CrossRef]

168. Kashuba, E.; Yurchenko, M.; Szirak, K.; Stahl, J.; Klein, G.; Szekely, L. Epstein-Barr virus-encoded EBNA-5 binds to Epstein-Barr virus-induced Fte1/S3a protein. Exp. Cell Res. 2005, 303, 47-55. [CrossRef] [PubMed]

169. Song, D.; Sakamoto, S.; Taniguchi, T. Inhibition of poly(ADP-ribose) polymerase activity by Bcl-2 in association with the ribosomal protein S3a. Biochemistry 2002, 41, 929-934. [CrossRef]

170. Dionne, K.L.; Bergeron, D.; Landry-Voyer, A.M.; Bachand, F. The $40 S$ ribosomal protein uS5 (RPS2) assembles into an extraribosomal complex with human ZNF277 that competes with the PRMT3-uS5 interaction. J. Biol. Chem. 2019, 294, $1944-1955$. [CrossRef]

171. Tchorzewski, M.; Boldyreff, B.; Grankowski, N. Extraribosomal function of the acidic ribosomal P1-protein YP1alpha from Saccharomyces cerevisiae. Acta Biochim. Pol. 1999, 46, 901-910. [CrossRef] [PubMed]

172. Guan, J.; Han, S.; Wu, J.; Zhang, Y.; Bai, M.; Abdullah, S.W.; Sun, S.; Guo, H. Ribosomal Protein L13 Participates in Innate Immune Response Induced by Foot-and-Mouth Disease Virus. Front. Immunol. 2021, 12, 616402. [CrossRef]

173. Carvalho, C.M.; Santos, A.A.; Pires, S.R.; Rocha, C.S.; Saraiva, D.I.; Machado, J.P.; Mattos, E.C.; Fietto, L.G.; Fontes, E.P. Regulated nuclear trafficking of rpL10A mediated by NIK1 represents a defense strategy of plant cells against virus. PLoS Pathog. 2008, 4, e1000247. [CrossRef] [PubMed]

174. Zorzatto, C.; Machado, J.P.; Lopes, K.V.; Nascimento, K.J.; Pereira, W.A.; Brustolini, O.J.; Reis, P.A.; Calil, I.P.; Deguchi, M.; Sachetto-Martins, G.; et al. NIK1-mediated translation suppression functions as a plant antiviral immunity mechanism. Nature 2015, 520, 679-682. [CrossRef]

175. Shen, B.; Arese, M.; Gualandris, A.; Rifkin, D.B. Intracellular association of FGF-2 with the ribosomal protein L6/TAXREB107. Biochem. Biophys. Res. Commun. 1998, 252, 524-528. [CrossRef]

176. Berghofer-Hochheimer, Y.; Zurek, C.; Wolfl, S.; Hemmerich, P.; Munder, T. L7 protein is a coregulator of vitamin D receptorretinoid $X$ receptor-mediated transactivation. J. Cell Biochem. 1998, 69, 1-12. [CrossRef]

177. Gray, J.P.; Davis, J.W., 2nd; Gopinathan, L.; Leas, T.L.; Nugent, C.A.; Vanden Heuvel, J.P. The ribosomal protein rpL11 associates with and inhibits the transcriptional activity of peroxisome proliferator-activated receptor-alpha. Toxicol. Sci. 2006, 89, 535-546. [CrossRef] [PubMed]

178. Imafuku, I.; Masaki, T.; Waragai, M.; Takeuchi, S.; Kawabata, M.; Hirai, S.; Ohno, S.; Nee, L.E.; Lippa, C.F.; Kanazawa, I.; et al. Presenilin 1 suppresses the function of c-Jun homodimers via interaction with QM/Jif-1. J. Cell Biol. 1999, 147, 121-134. [CrossRef] [PubMed]

179. Wan, F.; Anderson, D.E.; Barnitz, R.A.; Snow, A.; Bidere, N.; Zheng, L.; Hegde, V.; Lam, L.T.; Staudt, L.M.; Levens, D.; et al. Ribosomal protein S3: A KH domain subunit in NF-kappaB complexes that mediates selective gene regulation. Cell 2007, 131, 927-939. [CrossRef] [PubMed]

180. Sen, N.; Paul, B.D.; Gadalla, M.M.; Mustafa, A.K.; Sen, T.; Xu, R.; Kim, S.; Snyder, S.H. Hydrogen sulfide-linked sulfhydration of NF-kappaB mediates its antiapoptotic actions. Mol. Cell 2012, 45, 13-24. [CrossRef]

181. Huang, Z.; Zhang, Y.; Li, H.; Zhou, Y.; Zhang, Q.; Chen, R.; Jin, T.; Hu, K.; Li, S.; Wang, Y.; et al. Vitamin D promotes the cisplatin sensitivity of oral squamous cell carcinoma by inhibiting LCN2-modulated NF-kappaB pathway activation through RPS3. Cell Death Dis. 2019, 10, 936. [CrossRef]

182. Wan, F.; Weaver, A.; Gao, X.; Bern, M.; Hardwidge, P.R.; Lenardo, M.J. IKKbeta phosphorylation regulates RPS3 nuclear translocation and NF-kappaB function during infection with Escherichia coli strain O157:H7. Nat. Immunol. 2011, 12, 335-343. [CrossRef]

183. Yang, H.J.; Youn, H.; Seong, K.M.; Jin, Y.W.; Kim, J.; Youn, B. Phosphorylation of ribosomal protein S3 and antiapoptotic TRAF2 protein mediates radioresistance in non-small cell lung cancer cells. J. Biol. Chem. 2013, 288, 2965-2975. [CrossRef] [PubMed]

184. Wu, M.; El Qaidi, S.; Hardwidge, P.R. SseL Deubiquitinates RPS3 to Inhibit Its Nuclear Translocation. Pathogens 2018, 7, 86. [CrossRef] 
185. Yadavilli, S.; Mayo, L.D.; Higgins, M.; Lain, S.; Hegde, V.; Deutsch, W.A. Ribosomal protein S3: A multi-functional protein that interacts with both 553 and MDM2 through its KH domain. DNA Repair 2009, 8, 1215-1224. [CrossRef] [PubMed]

186. Kim, T.H.; Leslie, P.; Zhang, Y. Ribosomal proteins as unrevealed caretakers for cellular stress and genomic instability. Oncotarget 2014, 5, 860-871. [CrossRef]

187. He, X.; Li, Y.; Dai, M.S.; Sun, X.X. Ribosomal protein L4 is a novel regulator of the MDM2-p53 loop. Oncotarget 2016, 7, 16217-16226. [CrossRef]

188. Cho, J.; Park, J.; Shin, S.C.; Kim, J.H.; Kim, E.E.; Song, E.J. Ribosomal protein S2 interplays with MDM2 to induce p53. Biochem. Biophys. Res. Commun. 2020, 523, 542-547. [CrossRef]

189. Cho, J.; Park, J.; Shin, S.C.; Jang, M.; Kim, J.H.; Kim, E.E.; Song, E.J. USP47 Promotes Tumorigenesis by Negative Regulation of p53 through Deubiquitinating Ribosomal Protein S2. Cancers 2020, 12, 1137. [CrossRef] [PubMed]

190. Bai, D.; Zhang, J.; Xiao, W.; Zheng, X. Regulation of the HDM2-p53 pathway by ribosomal protein L6 in response to ribosomal stress. Nucleic Acids Res. 2014, 42, 1799-1811. [CrossRef]

191. Zhu, Y.; Poyurovsky, M.V.; Li, Y.; Biderman, L.; Stahl, J.; Jacq, X.; Prives, C. Ribosomal protein S7 is both a regulator and a substrate of MDM2. Mol. Cell 2009, 35, 316-326. [CrossRef]

192. Sun, X.X.; DeVine, T.; Challagundla, K.B.; Dai, M.S. Interplay between ribosomal protein S27a and MDM2 protein in p53 activation in response to ribosomal stress. J. Biol. Chem. 2011, 286, 22730-22741. [CrossRef] [PubMed]

193. Cao, B.; Fang, Z.; Liao, P.; Zhou, X.; Xiong, J.; Zeng, S.; Lu, H. Cancer-mutated ribosome protein L22 (RPL22/eL22) suppresses cancer cell survival by blocking p53-MDM2 circuit. Oncotarget 2017, 8, 90651-90661. [CrossRef]

194. Liu, Y.; Deisenroth, C.; Zhang, Y. RP-MDM2-p53 Pathway: Linking Ribosomal Biogenesis and Tumor Surveillance. Trends Cancer 2016, 2, 191-204. [CrossRef]

195. Wang, H.T.; Chen, T.Y.; Weng, C.W.; Yang, C.H.; Tang, M.S. Acrolein preferentially damages nucleolus eliciting ribosomal stress and apoptosis in human cancer cells. Oncotarget 2016, 7, 80450-80464. [CrossRef] [PubMed]

196. Mahata, B.; Sundqvist, A.; Xirodimas, D.P. Recruitment of RPL11 at promoter sites of p53-regulated genes upon nucleolar stress through NEDD8 and in an Mdm2-dependent manner. Oncogene 2012, 31, 3060-3071. [CrossRef]

197. Sundqvist, A.; Liu, G.; Mirsaliotis, A.; Xirodimas, D.P. Regulation of nucleolar signalling to p53 through NEDDylation of L11. EMBO Rep. 2009, 10, 1132-1139. [CrossRef]

198. Ebina, M.; Tsuruta, F.; Katoh, M.C.; Kigoshi, Y.; Someya, A.; Chiba, T. Myeloma overexpressed 2 (Myeov2) regulates L11 subnuclear localization through Nedd8 modification. PLoS ONE 2013, 8, e65285. [CrossRef]

199. Dai, M.S.; Challagundla, K.B.; Sun, X.X.; Palam, L.R.; Zeng, S.X.; Wek, R.C.; Lu, H. Physical and functional interaction between ribosomal protein L11 and the tumor suppressor ARF. J. Biol. Chem. 2012, 287, 17120-17129. [CrossRef]

200. Kayama, K.; Watanabe, S.; Takafuji, T.; Tsuji, T.; Hironaka, K.; Matsumoto, M.; Nakayama, K.I.; Enari, M.; Kohno, T.; Shiraishi, K.; et al. GRWD1 negatively regulates p53 via the RPL11-MDM2 pathway and promotes tumorigenesis. EMBO Rep. 2017, 18, 123-137. [CrossRef] [PubMed]

201. Fang, Z.; Cao, B.; Liao, J.M.; Deng, J.; Plummer, K.D.; Liao, P.; Liu, T.; Zhang, W.; Zhang, K.; Li, L.; et al. SPIN1 promotes tumorigenesis by blocking the uL18 (universal large ribosomal subunit protein 18)-MDM2-p53 pathway in human cancer. Elife 2018, 7, e31275. [CrossRef] [PubMed]

202. Cui, D.; Li, L.; Lou, H.; Sun, H.; Ngai, S.M.; Shao, G.; Tang, J. The ribosomal protein S26 regulates p53 activity in response to DNA damage. Oncogene 2014, 33, 2225-2235. [CrossRef]

203. Llanos, S.; Serrano, M. Depletion of ribosomal protein L37 occurs in response to DNA damage and activates p53 through the L11/MDM2 pathway. Cell Cycle 2010, 9, 4005-4012. [CrossRef]

204. Lindstrom, M.S.; Nister, M. Silencing of ribosomal protein S9 elicits a multitude of cellular responses inhibiting the growth of cancer cells subsequent to p53 activation. PLoS ONE 2010, 5, e9578. [CrossRef] [PubMed]

205. Xiong, X.; Zhao, Y.; He, H.; Sun, Y. Ribosomal protein S27-like and S27 interplay with p53-MDM2 axis as a target, a substrate and a regulator. Oncogene 2011, 30, 1798-1811. [CrossRef] [PubMed]

206. Pecoraro, A.; Carotenuto, P.; Russo, G.; Russo, A. Ribosomal protein uL3 targets E2F1 and Cyclin D1 in cancer cell response to nucleolar stress. Sci. Rep. 2019, 9, 15431. [CrossRef]

207. Zhou, X.; Hao, Q.; Zhang, Q.; Liao, J.M.; Ke, J.W.; Liao, P.; Cao, B.; Lu, H. Ribosomal proteins L11 and L5 activate TAp73 by overcoming MDM2 inhibition. Cell Death Differ. 2015, 22, 755-766. [CrossRef]

208. Gao, M.; Li, X.; Dong, W.; Jin, R.; Ma, H.; Yang, P.; Hu, M.; Li, Y.; Hao, Y.; Yuan, S.; et al. Ribosomal protein S7 regulates arsenite-induced GADD45alpha expression by attenuating MDM2-mediated GADD45alpha ubiquitination and degradation. Nucleic Acids Res. 2013, 41, 5210-5222. [CrossRef]

209. Coleno-Costes, A.; Jang, S.M.; de Vanssay, A.; Rougeot, J.; Bouceba, T.; Randsholt, N.B.; Gibert, J.M.; Le Crom, S.; Mouchel-Vielh, E.; Bloyer, S.; et al. New partners in regulation of gene expression: The enhancer of Trithorax and Polycomb Corto interacts with methylated ribosomal protein 112 via its chromodomain. PLoS Genet. 2012, 8, e1003006. [CrossRef]

210. Grunchec, H.; Deraze, J.; Dardalhon-Cumenal, D.; Ribeiro, V.; Coleno-Costes, A.; Dias, K.; Bloyer, S.; Mouchel-Vielh, E.; Peronnet, F.; Thomassin, H. Single amino-acid mutation in the Drosophila melanogaster ribosomal protein uL11: An insight in its transcriptional activity. bioRxiv 2021, 456895. [CrossRef]

211. Frolov, M.V.; Birchler, J.A. Mutation in P0, a dual function ribosomal protein/apurinic/apyrimidinic endonuclease, modifies gene expression and position effect variegation in Drosophila. Genetics 1998, 150, 1487-1495. [CrossRef] [PubMed] 
212. Kim, Y.K.; Kim, S.; Shin, Y.J.; Hur, Y.S.; Kim, W.Y.; Lee, M.S.; Cheon, C.I.; Verma, D.P. Ribosomal protein S6, a target of rapamycin, is involved in the regulation of rRNA genes by possible epigenetic changes in Arabidopsis. J. Biol. Chem. 2014, 289, 3901-3912. [CrossRef] [PubMed]

213. Son, O.; Kim, S.; Shin, Y.J.; Kim, W.Y.; Koh, H.J.; Cheon, C.I. Identification of nucleosome assembly protein 1 (NAP1) as an interacting partner of plant ribosomal protein S6 (RPS6) and a positive regulator of rDNA transcription. Biochem. Biophys. Res. Commun. 2015, 465, 200-205. [CrossRef]

214. Proshkin, S.A.; Shematorova, E.K.; Souslova, E.A.; Proshkina, G.M.; Shpakovski, G.V. A minor isoform of the human RNA polymerase II subunit hRPB11 (POLR2J) interacts with several components of the translation initiation factor eIF3. Biochemistry 2011, 76, 976-980. [CrossRef]

215. Harel-Sharvit, L.; Eldad, N.; Haimovich, G.; Barkai, O.; Duek, L.; Choder, M. RNA polymerase II subunits link transcription and mRNA decay to translation. Cell 2010, 143, 552-563. [CrossRef]

216. Moller, A.; Xie, S.Q.; Hosp, F.; Lang, B.; Phatnani, H.P.; James, S.; Ramirez, F.; Collin, G.B.; Naggert, J.K.; Babu, M.M.; et al. Proteomic analysis of mitotic RNA polymerase II reveals novel interactors and association with proteins dysfunctional in disease. Mol. Cell Proteom. 2012, 11, M111011767. [CrossRef] [PubMed]

217. Smekalova, E.M.; Gerashchenko, M.V.; O’Connor, P.B.F.; Whittaker, C.A.; Kauffman, K.J.; Fefilova, A.S.; Zatsepin, T.S.; Bogorad, R.L.; Baranov, P.V.; Langer, R.; et al. In Vivo RNAi-Mediated eIF3m Knockdown Affects Ribosome Biogenesis and Transcription but Has Limited Impact on mRNA-Specific Translation. Mol. Ther. Nucleic Acids 2020, 19, 252-266. [CrossRef]

218. Seither, P.; Iben, S.; Thiry, M.; Grummt, I. PAF67, a novel protein that is associated with the initiation-competent form of RNA polymerase I. Biol. Chem. 2001, 382, 1163-1170. [CrossRef]

219. Yuan, X.; Zhao, J.; Zentgraf, H.; Hoffmann-Rohrer, U.; Grummt, I. Multiple interactions between RNA polymerase I, TIF-IA and TAF(I) subunits regulate preinitiation complex assembly at the ribosomal gene promoter. EMBO Rep. 2002, 3, 1082-1087. [CrossRef]

220. DuRose, J.B.; Scheuner, D.; Kaufman, R.J.; Rothblum, L.I.; Niwa, M. Phosphorylation of eukaryotic translation initiation factor 2alpha coordinates rRNA transcription and translation inhibition during endoplasmic reticulum stress. Mol. Cell Biol. 2009, 29, 4295-4307. [CrossRef]

221. Jenkins, C.C.; Mata, J.; Crane, R.F.; Thomas, B.; Akoulitchev, A.; Bahler, J.; Norbury, C.J. Activation of AP-1-dependent transcription by a truncated translation initiation factor. Eukaryot Cell 2005, 4, 1840-1850. [CrossRef]

222. Esteves, P.; Dard, L.; Brillac, A.; Hubert, C.; Sarlak, S.; Rousseau, B.; Dumon, E.; Izotte, J.; Bonneu, M.; Lacombe, D.; et al. Nuclear control of lung cancer cells migration, invasion and bioenergetics by eukaryotic translation initiation factor 3F. Oncogene 2020, 39, 617-636. [CrossRef] [PubMed]

223. Shi, J.; Feng, Y.; Goulet, A.C.; Vaillancourt, R.R.; Sachs, N.A.; Hershey, J.W.; Nelson, M.A. The p34cdc2-related cyclin-dependent kinase 11 interacts with the p47 subunit of eukaryotic initiation factor 3 during apoptosis. J. Biol. Chem. 2003, $278,5062-5071$. [CrossRef] [PubMed]

224. Shi, J.; Hershey, J.W.; Nelson, M.A. Phosphorylation of the eukaryotic initiation factor $3 f$ by cyclin-dependent kinase 11 during apoptosis. FEBS Lett. 2009, 583, 971-977. [CrossRef] [PubMed]

225. Daxinger, L.; Oey, H.; Apedaile, A.; Sutton, J.; Ashe, A.; Whitelaw, E. A forward genetic screen identifies eukaryotic translation initiation factor 3, subunit $\mathrm{H}$ (eIF3h), as an enhancer of variegation in the mouse. G3 2012, 2, 1393-1396. [CrossRef]

226. Li, Y.; Fu, L.; Li, J.B.; Qin, Y.; Zeng, T.T.; Zhou, J.; Zeng, Z.L.; Chen, J.; Cao, T.T.; Ban, X.; et al. Increased expression of EIF5A2, via hypoxia or gene amplification, contributes to metastasis and angiogenesis of esophageal squamous cell carcinoma. Gastroenterology 2014, 146, 1701-1713. [CrossRef]

227. Sanders, J.; Brandsma, M.; Janssen, G.M.; Dijk, J.; Moller, W. Immunofluorescence studies of human fibroblasts demonstrate the presence of the complex of elongation factor-1 beta gamma delta in the endoplasmic reticulum. J. Cell Sci. 1996, 109 Pt 5, 1113-1117. [CrossRef]

228. Vera, M.; Pani, B.; Griffiths, L.A.; Muchardt, C.; Abbott, C.M.; Singer, R.H.; Nudler, E. The translation elongation factor eEF1A1 couples transcription to translation during heat shock response. Elife 2014, 16, 3164. [CrossRef]

229. Wu-Baer, F.; Lane, W.S.; Gaynor, R.B. Identification of a group of cellular cofactors that stimulate the binding of RNA polymerase II and TRP-185 to human immunodeficiency virus 1 TAR RNA. J. Biol. Chem. 1996, 271, 4201-4208. [CrossRef]

230. Billaut-Mulot, O.; Fernandez-Gomez, R.; Loyens, M.; Ouaissi, A. Trypanosoma cruzi elongation factor 1-alpha: Nuclear localization in parasites undergoing apoptosis. Gene 1996, 174, 19-26. [CrossRef]

231. Zolotarev, N.A.; Maksimenko, O.G.; Shidlovskii, Y.V.; Georgiev, P.G.; Bonchuk, A.N. [Translation elongation factor EF1 $\alpha 1$ interacts with ZAD domains of transcription factors from Drosophila melanogaster]. Mol. Biol. 2016, 50, 1014-1019. [CrossRef]

232. Maruyama, T.; Nara, K.; Yoshikawa, H.; Suzuki, N. Txk, a member of the non-receptor tyrosine kinase of the Tec family, forms a complex with poly(ADP-ribose) polymerase 1 and elongation factor 1alpha and regulates interferon-gamma gene transcription in Th1 cells. Clin. Exp. Immunol. 2007, 147, 164-175. [CrossRef] [PubMed]

233. Gangwani, L.; Mikrut, M.; Galcheva-Gargova, Z.; Davis, R.J. Interaction of ZPR1 with translation elongation factor-1alpha in proliferating cells. J. Cell Biol. 1998, 143, 1471-1484. [CrossRef]

234. Mishra, A.K.; Gangwani, L.; Davis, R.J.; Lambright, D.G. Structural insights into the interaction of the evolutionarily conserved ZPR1 domain tandem with eukaryotic EF1A, receptors, and SMN complexes. Proc. Natl. Acad. Sci. USA 2007, 104, 13930-13935. [CrossRef] [PubMed] 
235. Piazzi, M.; Bavelloni, A.; Faenza, I.; Blalock, W.; Urbani, A.; D’Aguanno, S.; Fiume, R.; Ramazzotti, G.; Maraldi, N.M.; Cocco, L. eEF1A phosphorylation in the nucleus of insulin-stimulated C2C12 myoblasts: Ser(5)(3) is a novel substrate for protein kinase C betaI. Mol. Cell Proteom. 2010, 9, 2719-2728. [CrossRef]

236. Negrutskii, B. Non-translational Connections of eEF1B in the Cytoplasm and Nucleus of Cancer Cells. Front. Mol. Biosci. 2020, 7, 56. [CrossRef] [PubMed]

237. Corbi, N.; Batassa, E.M.; Pisani, C.; Onori, A.; Di Certo, M.G.; Strimpakos, G.; Fanciulli, M.; Mattei, E.; Passananti, C. The eEF1gamma subunit contacts RNA polymerase II and binds vimentin promoter region. PLoS ONE 2010, 5, e14481. [CrossRef]

238. Pisani, C.; Onori, A.; Gabanella, F.; Delle Monache, F.; Borreca, A.; Ammassari-Teule, M.; Fanciulli, M.; Di Certo, M.G.; Passananti, C.; Corbi, N. eEF1Bgamma binds the Che-1 and TP53 gene promoters and their transcripts. J. Exp. Clin. Cancer Res. 2016, 35, 146. [CrossRef]

239. Fan, Y.; Schlierf, M.; Gaspar, A.C.; Dreux, C.; Kpebe, A.; Chaney, L.; Mathieu, A.; Hitte, C.; Gremy, O.; Sarot, E.; et al. Drosophila translational elongation factor-1gamma is modified in response to DOA kinase activity and is essential for cellular viability. Genetics 2010, 184, 141-154. [CrossRef]

240. Kaitsuka, T.; Tomizawa, K.; Matsushita, M. Transformation of eEF1Bdelta into heat-shock response transcription factor by alternative splicing. EMBO Rep. 2011, 12, 673-681. [CrossRef]

241. In, S.; Kim, Y.I.; Lee, J.E.; Kim, J. RNF20/40-mediated eEF1BdeltaL monoubiquitylation stimulates transcription of heat shockresponsive genes. Nucleic Acids Res. 2019, 47, 2840-2855. [CrossRef] [PubMed]

242. Wanzel, M.; Russ, A.C.; Kleine-Kohlbrecher, D.; Colombo, E.; Pelicci, P.G.; Eilers, M. A ribosomal protein L23-nucleophosmin circuit coordinates Mizl function with cell growth. Nat. Cell Biol. 2008, 10, 1051-1061. [CrossRef] [PubMed]

243. Yang, Z.Y.; Qu, Y.; Zhang, Q.; Wei, M.; Liu, C.X.; Chen, X.H.; Yan, M.; Zhu, Z.G.; Liu, B.Y.; Chen, G.Q.; et al. Knockdown of metallopanstimulin-1 inhibits NF-kappaB signaling at different levels: The role of apoptosis induction of gastric cancer cells. Int. J. Cancer 2012, 130, 2761-2770. [CrossRef] [PubMed]

244. Diao, M.Q.; Li, C.; Xu, J.D.; Zhao, X.F.; Wang, J.X. RPS27, a sORF-Encoded Polypeptide, Functions Antivirally by Activating the NF-kappaB Pathway and Interacting With Viral Envelope Proteins in Shrimp. Front. Immunol. 2019, 10, 2763. [CrossRef]

245. Lim, K.H.; Kim, K.H.; Choi, S.I.; Park, E.S.; Park, S.H.; Ryu, K.; Park, Y.K.; Kwon, S.Y.; Yang, S.I.; Lee, H.C.; et al. RPS3a over-expressed in HBV-associated hepatocellular carcinoma enhances the HBx-induced NF-kappaB signaling via its novel chaperoning function. PLoS ONE 2011, 6, e22258. [CrossRef]

246. Wang, A.; Xu, S.; Zhang, X.; He, J.; Yan, D.; Yang, Z.; Xiao, S. Ribosomal protein RPL41 induces rapid degradation of ATF4, a transcription factor critical for tumour cell survival in stress. J. Pathol. 2011, 225, 285-292. [CrossRef]

247. Harding, H.P.; Novoa, I.; Zhang, Y.; Zeng, H.; Wek, R.; Schapira, M.; Ron, D. Regulated translation initiation controls stressinduced gene expression in mammalian cells. Mol. Cell 2000, 6, 1099-1108. [CrossRef]

248. Xu, S.; Wu, X.; Zhang, X.; Chen, C.; Chen, H.; She, F. CagA orchestrates eEF1A1 and PKCdelta to induce interleukin-6 expression in Helicobacter pylori-infected gastric epithelial cells. Gut Pathog. 2020, 12, 31. [CrossRef]

249. Chen, L.; Uchida, K.; Endler, A.; Shibasaki, F. Mammalian tumor suppressor Int6 specifically targets hypoxia inducible factor 2 alpha for degradation by hypoxia- and pVHL-independent regulation. J. Biol. Chem. 2007, 282, 12707-12716. [CrossRef]

250. Moretti, J.; Chastagner, P.; Gastaldello, S.; Heuss, S.F.; Dirac, A.M.; Bernards, R.; Masucci, M.G.; Israel, A.; Brou, C. The translation initiation factor $3 \mathrm{f}$ (eIF3f) exhibits a deubiquitinase activity regulating Notch activation. PLoS Biol. 2010, 8, e1000545. [CrossRef]

251. Zhou, Z.; Zhou, H.; Ponzoni, L.; Luo, A.; Zhu, R.; He, M.; Huang, Y.; Guan, K.L.; Bahar, I.; Liu, Z.; et al. EIF3H Orchestrates Hippo Pathway-Mediated Oncogenesis via Catalytic Control of YAP Stability. Cancer Res. 2020, 80, 2550-2563. [CrossRef] [PubMed]

252. Guo, X.; Zhu, R.; Luo, A.; Zhou, H.; Ding, F.; Yang, H.; Liu, Z. EIF3H promotes aggressiveness of esophageal squamous cell carcinoma by modulating Snail stability. J. Exp. Clin. Cancer Res. 2020, 39, 175. [CrossRef] [PubMed]

253. Khacho, M.; Mekhail, K.; Pilon-Larose, K.; Pause, A.; Cote, J.; Lee, S. eEF1A is a novel component of the mammalian nuclear protein export machinery. Mol. Biol. Cell 2008, 19, 5296-5308. [CrossRef]

254. Li, L.; Ng, N.K.; Koon, A.C.; Chan, H.Y. Expanded polyalanine tracts function as nuclear export signals and promote protein mislocalization via eEF1A1 factor. J. Biol. Chem. 2017, 292, 5784-5800. [CrossRef] [PubMed]

255. Duman, M.; Vaquie, A.; Nocera, G.; Heller, M.; Stumpe, M.; Siva Sankar, D.; Dengjel, J.; Meijer, D.; Yamaguchi, T.; Matthias, P.; et al. EEF1A1 deacetylation enables transcriptional activation of remyelination. Nat. Commun. 2020, 11, 3420. [CrossRef]

256. Mingot, J.M.; Vega, S.; Cano, A.; Portillo, F.; Nieto, M.A. eEF1A mediates the nuclear export of SNAG-containing proteins via the Exportin5-aminoacyl-tRNA complex. Cell Rep. 2013, 5, 727-737. [CrossRef] [PubMed]

257. Calado, A.; Treichel, N.; Muller, E.C.; Otto, A.; Kutay, U. Exportin-5-mediated nuclear export of eukaryotic elongation factor 1A and tRNA. EMBO J. 2002, 21, 6216-6224. [CrossRef]

258. Huang, H.Y.; Hopper, A.K. In vivo biochemical analyses reveal distinct roles of beta-importins and eEF1A in tRNA subcellular traffic. Genes Dev. 2015, 29, 772-783. [CrossRef]

259. Wei, N.; Shi, Y.; Truong, L.N.; Fisch, K.M.; Xu, T.; Gardiner, E.; Fu, G.; Hsu, Y.O.; Kishi, S.; Su, A.I.; et al. Oxidative stress diverts tRNA synthetase to nucleus for protection against DNA damage. Mol. Cell 2014, 56, 323-332. [CrossRef]

260. Wei, N.; Cui, H.; Shi, Y.; Fu, G.; Rauniyar, N.; Yates, J.R.; Yang, X.-L. Nucleus translocation of tRNA synthetase mediates late integrated stress response. bioRxiv 2020, 138792. [CrossRef]

261. Cao, X.; Li, C.; Xiao, S.; Tang, Y.; Huang, J.; Zhao, S.; Li, X.; Li, J.; Zhang, R.; Yu, W. Acetylation promotes TyrRS nuclear translocation to prevent oxidative damage. Proc. Natl. Acad. Sci. USA 2017, 114, 687-692. [CrossRef] 
262. Bervoets, S.; Wei, N.; Erfurth, M.L.; Yusein-Myashkova, S.; Ermanoska, B.; Mateiu, L.; Asselbergh, B.; Blocquel, D.; Kakad, P.; Penserga, T.; et al. Transcriptional dysregulation by a nucleus-localized aminoacyl-tRNA synthetase associated with CharcotMarie-Tooth neuropathy. Nat. Commun. 2019, 10, 5045. [CrossRef] [PubMed]

263. Harb, M.; Becker, M.M.; Vitour, D.; Baron, C.H.; Vende, P.; Brown, S.C.; Bolte, S.; Arold, S.T.; Poncet, D. Nuclear localization of cytoplasmic poly(A)-binding protein upon rotavirus infection involves the interaction of NSP3 with eIF4G and RoXaN. J. Virol. 2008, 82, 11283-11293. [CrossRef] [PubMed]

264. Ma, S.; Bhattacharjee, R.B.; Bag, J. Expression of poly(A)-binding protein is upregulated during recovery from heat shock in HeLa cells. FEBS J. 2009, 276, 552-570. [CrossRef]

265. Salaun, C.; MacDonald, A.I.; Larralde, O.; Howard, L.; Lochtie, K.; Burgess, H.M.; Brook, M.; Malik, P.; Gray, N.K.; Graham, S.V. Poly(A)-binding protein 1 partially relocalizes to the nucleus during herpes simplex virus type 1 infection in an ICP27-independent manner and does not inhibit virus replication. J. Virol. 2010, 84, 8539-8548. [CrossRef]

266. Lee, Y.J.; Glaunsinger, B.A. Aberrant herpesvirus-induced polyadenylation correlates with cellular messenger RNA destruction. PLoS Biol. 2009, 7, e1000107. [CrossRef] [PubMed]

267. Dobrikova, E.; Shveygert, M.; Walters, R.; Gromeier, M. Herpes simplex virus proteins ICP27 and UL47 associate with polyadenylate-binding protein and control its subcellular distribution. J. Virol. 2010, 84, 270-279. [CrossRef]

268. Massimelli, M.J.; Majerciak, V.; Kruhlak, M.; Zheng, Z.M. Interplay between polyadenylate-binding protein 1 and Kaposi's sarcoma-associated herpesvirus ORF57 in accumulation of polyadenylated nuclear RNA, a viral long noncoding RNA. J. Virol. 2013, 87, 243-256. [CrossRef]

269. Park, R.; El-Guindy, A.; Heston, L.; Lin, S.F.; Yu, K.P.; Nagy, M.; Borah, S.; Delecluse, H.J.; Steitz, J.; Miller, G. Nuclear translocation and regulation of intranuclear distribution of cytoplasmic poly(A)-binding protein are distinct processes mediated by two Epstein Barr virus proteins. PLoS ONE 2014, 9, e92593. [CrossRef] [PubMed]

270. Duarte, M.; Vende, P.; Charpilienne, A.; Gratia, M.; Laroche, C.; Poncet, D. Rotavirus Infection Alters Splicing of the Stress-Related Transcription Factor XBP1. J. Virol. 2019, 93, e01739-18. [CrossRef]

271. Blakqori, G.; van Knippenberg, I.; Elliott, R.M. Bunyamwera orthobunyavirus S-segment untranslated regions mediate poly(A) tail-independent translation. J. Virol. 2009, 83, 3637-3646. [CrossRef]

272. Kanno, T.; Sato, Y.; Sata, T.; Katano, H. Expression of Kaposi's sarcoma-associated herpesvirus-encoded K10/10.1 protein in tissues and its interaction with poly(A)-binding protein. Virology 2006, 352, 100-109. [CrossRef] [PubMed]

273. Khaperskyy, D.A.; Emara, M.M.; Johnston, B.P.; Anderson, P.; Hatchette, T.F.; McCormick, C. Influenza a virus host shutoff disables antiviral stress-induced translation arrest. PLoS Pathog. 2014, 10, e1004217. [CrossRef]

274. Montero, H.; Rojas, M.; Arias, C.F.; Lopez, S. Rotavirus infection induces the phosphorylation of eIF2alpha but prevents the formation of stress granules. J. Virol. 2008, 82, 1496-1504. [CrossRef] [PubMed]

275. Beauchemin, C.; Laliberte, J.F. The poly(A) binding protein is internalized in virus-induced vesicles or redistributed to the nucleolus during turnip mosaic virus infection. J. Virol. 2007, 81, 10905-10913. [CrossRef]

276. Cheng, C.A.; Luo, J.M.; Chiang, M.H.; Fang, K.Y.; Li, C.H.; Chen, C.W.; Wang, Y.S.; Chang, C.Y. Nervous Necrosis Virus Coat Protein Mediates Host Translation Shutoff through Nuclear Translocalization and Degradation of Polyadenylate Binding Protein. J. Virol. 2021, 95, e0236420. [CrossRef]

277. Copeland, A.M.; Altamura, L.A.; Van Deusen, N.M.; Schmaljohn, C.S. Nuclear relocalization of polyadenylate binding protein during rift valley fever virus infection involves expression of the NSs gene. J. Virol. 2013, 87, 11659-11669. [CrossRef] [PubMed]

278. Borah, S.; Darricarrere, N.; Darnell, A.; Myoung, J.; Steitz, J.A. A viral nuclear noncoding RNA binds re-localized poly(A) binding protein and is required for late KSHV gene expression. PLoS Pathog. 2011, 7, e1002300. [CrossRef] [PubMed]

279. Kumar, G.R.; Glaunsinger, B.A. Nuclear import of cytoplasmic poly(A) binding protein restricts gene expression via hyperadenylation and nuclear retention of mRNA. Mol. Cell Biol. 2010, 30, 4996-5008. [CrossRef]

280. Burgess, H.M.; Richardson, W.A.; Anderson, R.C.; Salaun, C.; Graham, S.V.; Gray, N.K. Nuclear relocalisation of cytoplasmic poly(A)-binding proteins PABP1 and PABP4 in response to UV irradiation reveals mRNA-dependent export of metazoan PABPs. J. Cell Sci. 2011, 124, 3344-3355. [CrossRef] [PubMed]

281. Afonina, E.; Stauber, R.; Pavlakis, G.N. The human poly(A)-binding protein 1 shuttles between the nucleus and the cytoplasm. J. Biol. Chem. 1998, 273, 13015-13021. [CrossRef]

282. Hosoda, N.; Lejeune, F.; Maquat, L.E. Evidence that poly(A) binding protein C1 binds nuclear pre-mRNA poly(A) tails. Mol. Cell Biol. 2006, 26, 3085-3097. [CrossRef]

283. Burgess, H.M.; Gray, N.K. An integrated model for the nucleo-cytoplasmic transport of cytoplasmic poly(A)-binding proteins. Commun. Integr Biol. 2012, 5, 243-247. [CrossRef] [PubMed]

284. Dai, L.; Taylor, M.S.; O'Donnell, K.A.; Boeke, J.D. Poly(A) binding protein C1 is essential for efficient L1 retrotransposition and affects L1 RNP formation. Mol. Cell Biol. 2012, 32, 4323-4336. [CrossRef]

285. Rivas, H.G.; Schmaling, S.K.; Gaglia, M.M. Shutoff of Host Gene Expression in Influenza A Virus and Herpesviruses: Similar Mechanisms and Common Themes. Viruses 2016, 8, 102. [CrossRef]

286. Kumar, G.R.; Shum, L.; Glaunsinger, B.A. Importin alpha-mediated nuclear import of cytoplasmic poly(A) binding protein occurs as a direct consequence of cytoplasmic mRNA depletion. Mol. Cell Biol. 2011, 31, 3113-3125. [CrossRef] [PubMed]

287. Gilbertson, S.; Federspiel, J.D.; Hartenian, E.; Cristea, I.M.; Glaunsinger, B. Changes in mRNA abundance drive shuttling of RNA binding proteins, linking cytoplasmic RNA degradation to transcription. Elife 2018, 7, e37663. [CrossRef] [PubMed] 
288. Hartenian, E.; Glaunsinger, B.A. Feedback to the central dogma: Cytoplasmic mRNA decay and transcription are interdependent processes. Crit. Rev. Biochem. Mol. Biol. 2019, 54, 385-398. [CrossRef]

289. Duncan-Lewis, C.; Hartenian, E.; King, V.; Glaunsinger, B.A. Cytoplasmic mRNA decay represses RNA polymerase II transcription during early apoptosis. Elife 2021, 10, e58342. [CrossRef] [PubMed]

290. Shih, J.W.; Wang, W.T.; Tsai, T.Y.; Kuo, C.Y.; Li, H.K.; Wu Lee, Y.H. Critical roles of RNA helicase DDX3 and its interactions with eIF4E/PABP1 in stress granule assembly and stress response. Biochem. J. 2012, 441, 119-129. [CrossRef] [PubMed]

291. Copsey, A.C.; Cooper, S.; Parker, R.; Lineham, E.; Lapworth, C.; Jallad, D.; Sweet, S.; Morley, S.J. The helicase, DDX3X, interacts with poly(A)-binding protein 1 (PABP1) and caprin-1 at the leading edge of migrating fibroblasts and is required for efficient cell spreading. Biochem. J. 2017, 474, 3109-3120. [CrossRef]

292. Woods, A.J.; Kantidakis, T.; Sabe, H.; Critchley, D.R.; Norman, J.C. Interaction of paxillin with poly(A)-binding protein 1 and its role in focal adhesion turnover and cell migration. Mol. Cell Biol. 2005, 25, 3763-3773. [CrossRef]

293. Eisermann, K.; Dar, J.A.; Dong, J.; Wang, D.; Masoodi, K.Z.; Wang, Z. Poly (A) Binding Protein Cytoplasmic 1 Is a Novel Co-Regulator of the Androgen Receptor. PLoS ONE 2015, 10, e0128495. [CrossRef]

294. Sen, A.; De Castro, I.; Defranco, D.B.; Deng, F.M.; Melamed, J.; Kapur, P.; Raj, G.V.; Rossi, R.; Hammes, S.R. Paxillin mediates extranuclear and intranuclear signaling in prostate cancer proliferation. J. Clin. Investig. 2012, 122, 2469-2481. [CrossRef] [PubMed]

295. Kamiyama, T.; Sun, W.; Tani, N.; Nakamura, A.; Niwa, R. Poly(A) Binding Protein Is Required for Nuclear Localization of the Ecdysteroidogenic Transcription Factor Molting Defective in the Prothoracic Gland of Drosophila melanogaster. Front. Genet. 2020, 11, 636. [CrossRef]

296. Brune, C.; Munchel, S.E.; Fischer, N.; Podtelejnikov, A.V.; Weis, K. Yeast poly(A)-binding protein Pab1 shuttles between the nucleus and the cytoplasm and functions in mRNA export. RNA 2005, 11, 517-531. [CrossRef]

297. Minvielle-Sebastia, L.; Preker, P.J.; Wiederkehr, T.; Strahm, Y.; Keller, W. The major yeast poly(A)-binding protein is associated with cleavage factor IA and functions in premessenger RNA 3'-end formation. Proc. Natl. Acad. Sci. USA 1997, 94, 7897-7902. [CrossRef]

298. Khaleghpour, K.; Svitkin, Y.V.; Craig, A.W.; DeMaria, C.T.; Deo, R.C.; Burley, S.K.; Sonenberg, N. Translational repression by a novel partner of human poly(A) binding protein, Paip2. Mol. Cell 2001, 7, 205-216. [CrossRef]

299. Kachaev, Z.M.; Lebedeva, L.A.; Kozlov, E.N.; Toropygin, I.Y.; Schedl, P.; Shidlovskii, Y.V. Paip2 is localized to active promoters and loaded onto nascent mRNA in Drosophila. Cell Cycle 2018, 17, 1708-1720. [CrossRef] [PubMed]

300. Kachaev, Z.M.; Lebedeva, L.A.; Shaposhnikov, A.V.; Moresco, J.J.; Yates, J.R., 3rd; Schedl, P.; Shidlovskii, Y.V. Paip2 cooperates with Cbp80 at an active promoter and participates in RNA Polymerase II phosphorylation in Drosophila. FEBS Lett. 2019, 593, 1102-1112. [CrossRef]

301. Kachaev, Z.M.; Lebedeva, L.A.; Kozlov, E.N.; Shidlovskii, Y.V. Interplay of mRNA capping and transcription machineries. BioSci. Rep. 2020, 40, BSR20192825. [CrossRef]

302. Wool, I.G. Extraribosomal functions of ribosomal proteins. Trends Biochem. Sci. 1996, 21, 164-165. [CrossRef]

303. Lindstrom, M.S. Emerging functions of ribosomal proteins in gene-specific transcription and translation. Biochem. Biophys. Res. Commun. 2009, 379, 167-170. [CrossRef] [PubMed]

304. Warner, J.R.; McIntosh, K.B. How common are extraribosomal functions of ribosomal proteins? Mol. Cell 2009, 34, 3-11. [CrossRef]

305. Malygin, A.A.; Parakhnevitch, N.M.; Ivanov, A.V.; Eperon, I.C.; Karpova, G.G. Human ribosomal protein S13 regulates expression of its own gene at the splicing step by a feedback mechanism. Nucleic Acids Res. 2007, 35, 6414-6423. [CrossRef]

306. Petibon, C.; Parenteau, J.; Catala, M.; Elela, S.A. Introns regulate the production of ribosomal proteins by modulating splicing of duplicated ribosomal protein genes. Nucleic Acids Res. 2016, 44, 3878-3891. [CrossRef]

307. Fewell, S.W.; Woolford, J.L., Jr. Ribosomal protein S14 of Saccharomyces cerevisiae regulates its expression by binding to RPS14B pre-mRNA and to 18S rRNA. Mol. Cell Biol. 1999, 19, 826-834. [CrossRef] [PubMed]

308. Li, Z.; Paulovich, A.G.; Woolford, J.L., Jr. Feedback inhibition of the yeast ribosomal protein gene CRY2 is mediated by the nucleotide sequence and secondary structure of CRY2 pre-mRNA. Mol. Cell Biol. 1995, 15, 6454-6464. [CrossRef]

309. Ivanov, A.V.; Malygin, A.A.; Karpova, G.G. Human ribosomal protein S26 suppresses the splicing of its pre-mRNA. Biochim. Biophys. Acta 2005, 1727, 134-140. [CrossRef]

310. Cuccurese, M.; Russo, G.; Russo, A.; Pietropaolo, C. Alternative splicing and nonsense-mediated mRNA decay regulate mammalian ribosomal gene expression. Nucleic Acids Res. 2005, 33, 5965-5977. [CrossRef]

311. Bozzoni, I.; Fragapane, P.; Annesi, F.; Pierandrei-Amaldi, P.; Amaldi, F.; Beccari, E. Expression of two Xenopus laevis ribosomal protein genes in injected frog oocytes. A specific splicing block interfeRes. with the L1 RNA maturation. J. Mol. Biol. 1984, 180, 987-1005. [CrossRef]

312. Takei, S.; Togo-Ohno, M.; Suzuki, Y.; Kuroyanagi, H. Evolutionarily conserved autoregulation of alternative pre-mRNA splicing by ribosomal protein L10a. Nucleic Acids Res. 2016, 44, 5585-5596. [CrossRef] [PubMed]

313. Mitrovich, Q.M.; Anderson, P. Unproductively spliced ribosomal protein mRNAs are natural targets of mRNA surveillance in C. elegans. Genes Dev. 2000, 14, 2173-2184. [CrossRef]

314. Gabunilas, J.; Chanfreau, G. Splicing-Mediated Autoregulation Modulates Rpl22p Expression in Saccharomyces cerevisiae. PLoS Genet. 2016, 12, e1005999. [CrossRef] [PubMed] 
315. Vilardell, J.; Warner, J.R. Regulation of splicing at an intermediate step in the formation of the spliceosome. Genes Dev. 1994, 8, 211-220. [CrossRef]

316. White, S.A.; Hoeger, M.; Schweppe, J.J.; Shillingford, A.; Shipilov, V.; Zarutskie, J. Internal loop mutations in the ribosomal protein L30 binding site of the yeast L30 RNA transcript. RNA 2004, 10, 369-377. [CrossRef]

317. Eng, F.J.; Warner, J.R. Structural basis for the regulation of splicing of a yeast messenger RNA. Cell 1991, 65, 797-804. [CrossRef]

318. Dabeva, M.D.; Warner, J.R. Ribosomal protein L32 of Saccharomyces cerevisiae regulates both splicing and translation of its own transcript. J. Biol. Chem. 1993, 268, 19669-19674. [CrossRef]

319. Parenteau, J.; Durand, M.; Morin, G.; Gagnon, J.; Lucier, J.F.; Wellinger, R.J.; Chabot, B.; Elela, S.A. Introns within ribosomal protein genes regulate the production and function of yeast ribosomes. Cell 2011, 147, 320-331. [CrossRef] [PubMed]

320. Parenteau, J.; Maignon, L.; Berthoumieux, M.; Catala, M.; Gagnon, V.; Abou Elela, S. Introns are mediators of cell response to starvation. Nature 2019, 565, 612-617. [CrossRef]

321. Russo, A.; Siciliano, G.; Catillo, M.; Giangrande, C.; Amoresano, A.; Pucci, P.; Pietropaolo, C.; Russo, G. hnRNP H1 and intronic G runs in the splicing control of the human rpL3 gene. Biochim. Biophys. Acta 2010, 1799, 419-428. [CrossRef]

322. Russo, A.; Catillo, M.; Esposito, D.; Briata, P.; Pietropaolo, C.; Russo, G. Autoregulatory circuit of human rpL3 expression requiRes. hnRNP H1, NPM and KHSRP. Nucleic Acids Res. 2011, 39, 7576-7585. [CrossRef]

323. Zhang, Y.; O'Leary, M.N.; Peri, S.; Wang, M.; Zha, J.; Melov, S.; Kappes, D.J.; Feng, Q.; Rhodes, J.; Amieux, P.S.; et al. Ribosomal Proteins Rpl22 and Rpl2211 Control Morphogenesis by Regulating Pre-mRNA Splicing. Cell Rep. 2017, 18, 545-556. [CrossRef] [PubMed]

324. Abrhamova, K.; Nemcko, F.; Libus, J.; Prevorovsky, M.; Halova, M.; Puta, F.; Folk, P. Introns provide a platform for intergenic regulatory feedback of RPL22 paralogs in yeast. PLoS ONE 2018, 13, e0190685. [CrossRef]

325. Chen, J.; Crutchley, J.; Zhang, D.; Owzar, K.; Kastan, M.B. Identification of a DNA Damage-Induced Alternative Splicing Pathway That Regulates p53 and Cellular Senescence Markers. Cancer Discov. 2017, 7, 766-781. [CrossRef]

326. Gopanenko, A.V.; Malygin, A.A.; Tupikin, A.E.; Laktionov, P.P.; Kabilov, M.R.; Karpova, G.G. Human ribosomal protein eS1 is engaged in cellular events related to processing and functioning of U11 snRNA. Nucleic Acids Res. 2017, 45, 9121-9137. [CrossRef] [PubMed]

327. Li, S.; Liu, K.; Zhang, S.; Wang, X.; Rogers, K.; Ren, G.; Zhang, C.; Yu, B. STV1, a ribosomal protein, binds primary microRNA transcripts to promote their interaction with the processing complex in Arabidopsis. Proc. Natl. Acad. Sci. USA 2017, 114, 1424-1429. [CrossRef]

328. Dostie, J.; Lejbkowicz, F.; Sonenberg, N. Nuclear eukaryotic initiation factor 4E (eIF4E) colocalizes with splicing factors in speckles. J. Cell Biol. 2000, 148, 239-247. [CrossRef]

329. Graham, P.L.; Yanowitz, J.L.; Penn, J.K.; Deshpande, G.; Schedl, P. The translation initiation factor eIF4E regulates the sex-specific expression of the master switch gene Sxl in Drosophila melanogaster. PLoS Genet. 2011, 7, e1002185. [CrossRef]

330. Davis, M.R.; Delaleau, M.; Borden, K.L.B. Nuclear eIF4E Stimulates 3'-End Cleavage of Target RNAs. Cell Rep. 2019, 27, 1397-1408.e4. [CrossRef]

331. Culjkovic-Kraljacic, B.; Skrabanek, L.; Revuelta, M.V.; Gasiorek, J.; Cowling, V.H.; Cerchietti, L.; Borden, K.L.B. The eukaryotic translation initiation factor eIF4E elevates steady-state m(7)G capping of coding and noncoding transcripts. Proc. Natl. Acad. Sci. USA 2020, 117, 26773-26783. [CrossRef] [PubMed]

332. Shi, Y.; Di Giammartino, D.C.; Taylor, D.; Sarkeshik, A.; Rice, W.J.; Yates, J.R., 3rd; Frank, J.; Manley, J.L. Molecular architecture of the human pre-mRNA $3^{\prime}$ processing complex. Mol. Cell 2009, 33, 365-376. [CrossRef]

333. Gross, S.; Moore, C. Five subunits are required for reconstitution of the cleavage and polyadenylation activities of Saccharomyces cerevisiae cleavage factor I. Proc. Natl. Acad. Sci. USA 2001, 98, 6080-6085. [CrossRef] [PubMed]

334. Kessler, M.M.; Zhao, J.; Moore, C.L. Purification of the Saccharomyces cerevisiae cleavage/polyadenylation factor I. Separation into two components that are required for both cleavage and polyadenylation of mRNA $3^{\prime}$ ends. J. Biol. Chem. 1996, 271, 27167-27175. [CrossRef] [PubMed]

335. Morris, C.; Wittmann, J.; Jack, H.M.; Jalinot, P. Human INT6/eIF3e is required for nonsense-mediated mRNA decay. EMBO Rep. 2007, 8, 596-602. [CrossRef]

336. Lee, S.Y.; Ramirez, J.; Franco, M.; Lectez, B.; Gonzalez, M.; Barrio, R.; Mayor, U. Ube3a, the E3 ubiquitin ligase causing Angelman syndrome and linked to autism, regulates protein homeostasis through the proteasomal shuttle Rpn10. Cell Mol. Life Sci. 2014, 71, 2747-2758. [CrossRef] [PubMed]

337. Park, J.W.; Parisky, K.; Celotto, A.M.; Reenan, R.A.; Graveley, B.R. Identification of alternative splicing regulators by RNA interference in Drosophila. Proc. Natl. Acad. Sci. USA 2004, 101, 15974-15979. [CrossRef]

338. Zhan, X.; Yan, C.; Zhang, X.; Lei, J.; Shi, Y. Structure of a human catalytic step I spliceosome. Science 2018, 359, 537-545. [CrossRef]

339. Kanellis, D.C.; Espinoza, J.A.; Zisi, A.; Sakkas, E.; Bartkova, J.; Katsori, A.M.; Bostrom, J.; Dyrskjot, L.; Broholm, H.; Altun, M.; et al. The exon-junction complex helicase eIF4A3 controls cell fate via coordinated regulation of ribosome biogenesis and translational output. Sci. Adv. 2021, 7, eabf7561. [CrossRef]

340. Koroleva, O.A.; Calder, G.; Pendle, A.F.; Kim, S.H.; Lewandowska, D.; Simpson, C.G.; Jones, I.M.; Brown, J.W.; Shaw, P.J. Dynamic behavior of Arabidopsis eIF4A-III, putative core protein of exon junction complex: Fast relocation to nucleolus and splicing speckles under hypoxia. Plant Cell 2009, 21, 1592-1606. [CrossRef] 
341. Cui, P.; Chen, T.; Qin, T.; Ding, F.; Wang, Z.; Chen, H.; Xiong, L. The RNA Polymerase II C-Terminal Domain Phosphatase-Like Protein FIERY2/CPL1 Interacts with eIF4AIII and Is Essential for Nonsense-Mediated mRNA Decay in Arabidopsis. Plant Cell 2016, 28, 770-785. [CrossRef]

342. McKendrick, L.; Thompson, E.; Ferreira, J.; Morley, S.J.; Lewis, J.D. Interaction of eukaryotic translation initiation factor 4G with the nuclear cap-binding complex provides a link between nuclear and cytoplasmic functions of the m(7) guanosine cap. Mol. Cell Biol. 2001, 21, 3632-3641. [CrossRef]

343. Kafasla, P.; Barrass, J.D.; Thompson, E.; Fromont-Racine, M.; Jacquier, A.; Beggs, J.D.; Lewis, J. Interaction of yeast eIF4G with spliceosome components: Implications in pre-mRNA processing events. RNA Biol. 2009, 6, 563-574. [CrossRef]

344. Hu, J.; Sun, F.; Handel, M.A. Nuclear localization of EIF4G3 suggests a role for the XY body in translational regulation during spermatogenesis in mice. Biol. Reprod. 2018, 98, 102-114. [CrossRef] [PubMed]

345. Ivshina, M.; Lasko, P.; Richter, J.D. Cytoplasmic polyadenylation element binding proteins in development, health, and disease. Annu. Rev. Cell Dev. Biol. 2014, 30, 393-415. [CrossRef]

346. Kozlov, E.; Shidlovskii, Y.V.; Gilmutdinov, R.; Schedl, P.; Zhukova, M. The role of CPEB family proteins in the nervous system function in the norm and pathology. Cell BioSci. 2021, 11, 64. [CrossRef]

347. Kan, M.C.; Oruganty-Das, A.; Cooper-Morgan, A.; Jin, G.; Swanger, S.A.; Bassell, G.J.; Florman, H.; van Leyen, K.; Richter, J.D. CPEB4 is a cell survival protein retained in the nucleus upon ischemia or endoplasmic reticulum calcium depletion. Mol. Cell Biol. 2010, 30, 5658-5671. [CrossRef]

348. Ernoult-Lange, M.; Wilczynska, A.; Harper, M.; Aigueperse, C.; Dautry, F.; Kress, M.; Weil, D. Nucleocytoplasmic traffic of CPEB1 and accumulation in Crm1 nucleolar bodies. Mol. Biol. Cell 2009, 20, 176-187. [CrossRef] [PubMed]

349. Lin, C.L.; Evans, V.; Shen, S.; Xing, Y.; Richter, J.D. The nuclear experience of CPEB: Implications for RNA processing and translational control. RNA 2010, 16, 338-348. [CrossRef] [PubMed]

350. Bava, F.A.; Eliscovich, C.; Ferreira, P.G.; Miñana, B.; Ben-Dov, C.; Guigó, R.; Valcárcel, J.; Méndez, R. CPEB1 coordinates alternative 3'-UTR formation with translational regulation. Nature 2013, 495, 121-125. [CrossRef]

351. Qu, W.; Jin, H.; Chen, B.P.; Liu, J.; Li, R.; Guo, W.; Tian, H. CPEB3 regulates neuron-specific alternative splicing and involves neurogenesis gene expression. Aging 2020, 13, 2330-2347. [CrossRef] [PubMed]

352. Chao, H.W.; Lai, Y.T.; Lu, Y.L.; Lin, C.L.; Mai, W.; Huang, Y.S. NMDAR signaling facilitates the IPO5-mediated nuclear import of CPEB3. Nucleic Acids Res. 2012, 40, 8484-8498. [CrossRef]

353. Peng, S.C.; Lai, Y.T.; Huang, H.Y.; Huang, H.D.; Huang, Y.S. A novel role of CPEB3 in regulating EGFR gene transcription via association with Stat5b in neurons. Nucleic Acids Res. 2010, 38, 7446-7457. [CrossRef]

354. Culjkovic, B.; Topisirovic, I.; Skrabanek, L.; Ruiz-Gutierrez, M.; Borden, K.L. eIF4E promotes nuclear export of cyclin D1 mRNAs via an element in the $3^{\prime}$ UTR. J. Cell Biol. 2005, 169, 245-256. [CrossRef]

355. Culjkovic-Kraljacic, B.; Baguet, A.; Volpon, L.; Amri, A.; Borden, K.L. The oncogene eIF4E reprograms the nuclear pore complex to promote mRNA export and oncogenic transformation. Cell Rep. 2012, 2, 207-215. [CrossRef]

356. Culjkovic, B.; Topisirovic, I.; Skrabanek, L.; Ruiz-Gutierrez, M.; Borden, K.L. eIF4E is a central node of an RNA regulon that governs cellular proliferation. J. Cell Biol. 2006, 175, 415-426. [CrossRef]

357. Topisirovic, I.; Siddiqui, N.; Lapointe, V.L.; Trost, M.; Thibault, P.; Bangeranye, C.; Pinol-Roma, S.; Borden, K.L. Molecular dissection of the eukaryotic initiation factor 4E (eIF4E) export-competent RNP. EMBO J. 2009, 28, 1087-1098. [CrossRef] [PubMed]

358. Volpon, L.; Culjkovic-Kraljacic, B.; Sohn, H.S.; Blanchet-Cohen, A.; Osborne, M.J.; Borden, K.L.B. A biochemical framework for eIF4E-dependent mRNA export and nuclear recycling of the export machinery. RNA 2017, 23, 927-937. [CrossRef] [PubMed]

359. Cohen, N.; Sharma, M.; Kentsis, A.; Perez, J.M.; Strudwick, S.; Borden, K.L. PML RING suppresses oncogenic transformation by reducing the affinity of eIF4E for mRNA. EMBO J. 2001, 20, 4547-4559. [CrossRef]

360. Topisirovic, I.; Kentsis, A.; Perez, J.M.; Guzman, M.L.; Jordan, C.T.; Borden, K.L. Eukaryotic translation initiation factor 4E activity is modulated by HOXA9 at multiple levels. Mol. Cell Biol. 2005, 25, 1100-1112. [CrossRef]

361. Rosorius, O.; Reichart, B.; Kratzer, F.; Heger, P.; Dabauvalle, M.C.; Hauber, J. Nuclear pore localization and nucleocytoplasmic transport of eIF-5A: Evidence for direct interaction with the export receptor CRM1. J. Cell Sci. 1999, 112 Pt 14, $2369-2380$. [CrossRef]

362. Elfgang, C.; Rosorius, O.; Hofer, L.; Jaksche, H.; Hauber, J.; Bevec, D. Evidence for specific nucleocytoplasmic transport pathways used by leucine-rich nuclear export signals. Proc. Natl. Acad. Sci. USA 1999, 96, 6229-6234. [CrossRef]

363. Ruhl, M.; Himmelspach, M.; Bahr, G.M.; Hammerschmid, F.; Jaksche, H.; Wolff, B.; Aschauer, H.; Farrington, G.K.; Probst, H.; Bevec, D.; et al. Eukaryotic initiation factor 5A is a cellular target of the human immunodeficiency virus type 1 Rev. activation domain mediating trans-activation. J. Cell Biol. 1993, 123, 1309-1320. [CrossRef]

364. Bevec, D.; Jaksche, H.; Oft, M.; Wohl, T.; Himmelspach, M.; Pacher, A.; Schebesta, M.; Koettnitz, K.; Dobrovnik, M.; Csonga, R.; et al. Inhibition of HIV-1 replication in lymphocytes by mutants of the Rev. cofactor eIF-5A. Science 1996, 271, 1858-1860. [CrossRef]

365. Katahira, J.; Ishizaki, T.; Sakai, H.; Adachi, A.; Yamamoto, K.; Shida, H. Effects of translation initiation factor eIF-5A on the functioning of human T-cell leukemia virus type I Rex and human immunodeficiency virus Rev. inhibited trans dominantly by a Rex mutant deficient in RNA binding. J. Virol. 1995, 69, 3125-3133. [CrossRef] [PubMed]

366. Balukoff, N.C.; Ho, J.J.D.; Theodoridis, P.R.; Wang, M.; Bokros, M.; Llanio, L.M.; Krieger, J.R.; Schatz, J.H.; Lee, S. A translational program that suppresses metabolism to shield the genome. Nat. Commun. 2020, 11, 5755. [CrossRef] 
367. Gobert, A.P.; Finley, J.L.; Latour, Y.L.; Asim, M.; Smith, T.M.; Verriere, T.G.; Barry, D.P.; Allaman, M.M.; Delagado, A.G.; Rose, K.L.; et al. Hypusination Orchestrates the Antimicrobial Response of Macrophages. Cell Rep. 2020, 33, 108510. [CrossRef] [PubMed]

368. Maier, B.; Ogihara, T.; Trace, A.P.; Tersey, S.A.; Robbins, R.D.; Chakrabarti, S.K.; Nunemaker, C.S.; Stull, N.D.; Taylor, C.A.; Thompson, J.E.; et al. The unique hypusine modification of eIF5A promotes islet beta cell inflammation and dysfunction in mice. J. Clin. Investig. 2010, 120, 2156-2170. [CrossRef] [PubMed]

369. Kruse, M.; Rosorius, O.; Kratzer, F.; Bevec, D.; Kuhnt, C.; Steinkasserer, A.; Schuler, G.; Hauber, J. Inhibition of CD83 cell surface expression during dendritic cell maturation by interference with nuclear export of CD83 mRNA. J. Exp. Med. 2000, 191, 1581-1590. [CrossRef]

370. Bohm, M.; Sawicka, K.; Siebrasse, J.P.; Brehmer-Fastnacht, A.; Peters, R.; Klempnauer, K.H. The transformation suppressor protein Pdcd4 shuttles between nucleus and cytoplasm and binds RNA. Oncogene 2003, 22, 4905-4910. [CrossRef]

371. Tran, T.T.; Rane, C.K.; Zito, C.R.; Weiss, S.A.; Jessel, S.; Lucca, L.; Lu, B.Y.; Oria, V.O.; Adeniran, A.; Chiang, V.L.; et al. Clinical Significance of PDCD4 in Melanoma by Subcellular Expression and in Tumor-Associated Immune Cells. Cancers 2021, 13, 1049. [CrossRef]

372. Sasaki, M.; Kawahara, K.; Nishio, M.; Mimori, K.; Kogo, R.; Hamada, K.; Itoh, B.; Wang, J.; Komatsu, Y.; Yang, Y.R.; et al. Regulation of the MDM2-P53 pathway and tumor growth by PICT1 via nucleolar RPL11. Nat. Med. 2011, 17, 944-951. [CrossRef]

373. Chen, H.; Han, L.; Tsai, H.; Wang, Z.; Wu, Y.; Duo, Y.; Cao, W.; Chen, L.; Tan, Z.; Xu, N.; et al. PICT-1 is a key nucleolar sensor in DNA damage response signaling that regulates apoptosis through the RPL11-MDM2-p53 pathway. Oncotarget 2016, 7, 83241-83257. [CrossRef] [PubMed]

374. Nishimura, K.; Kumazawa, T.; Kuroda, T.; Katagiri, N.; Tsuchiya, M.; Goto, N.; Furumai, R.; Murayama, A.; Yanagisawa, J.; Kimura, K. Perturbation of ribosome biogenesis drives cells into senescence through 5S RNP-mediated p53 activation. Cell Rep. 2015, 10, 1310-1323. [CrossRef]

375. Fregoso, O.I.; Das, S.; Akerman, M.; Krainer, A.R. Splicing-factor oncoprotein SRSF1 stabilizes p53 via RPL5 and induces cellular senescence. Mol. Cell 2013, 50, 56-66. [CrossRef]

376. Zhou, H.; Zhang, J.; Gu, Y.; Gan, X.; Gan, Y.; Zheng, W.; Kim, B.W.; Xu, X.; Lu, X.; Dong, Q.; et al. Identification of a novel RNA giant nuclear body in cancer cells. Oncotarget 2016, 7, 4724-4734. [CrossRef]

377. Lobo, M.V.; Martin, M.E.; Perez, M.I.; Alonso, F.J.; Redondo, C.; Alvarez, M.I.; Salinas, M. Levels, phosphorylation status and cellular localization of translational factor eIF2 in gastrointestinal carcinomas. HistoChem. J. 2000, 32, 139-150. [CrossRef]

378. Tejada, S.; Lobo, M.V.; Garcia-Villanueva, M.; Sacristan, S.; Perez-Morgado, M.I.; Salinas, M.; Martin, M.E. Eukaryotic initiation factors (eIF) 2alpha and $4 \mathrm{E}$ expression, localization, and phosphorylation in brain tumors. J. HistoChem. CytoChem. 2009, 57, 503-512. [CrossRef] [PubMed]

379. Watkins, S.J.; Norbury, C.J. Cell cycle-related variation in subcellular localization of eIF3e/INT6 in human fibroblasts. Cell Prolif. 2004, 37, 149-160. [CrossRef] [PubMed]

380. Pisera, A.; Campo, A.; Campo, S. Structure and functions of the translation initiation factor eIF4E and its role in cancer development and treatment. J. Genet. Genom. 2018, 45, 13-24. [CrossRef]

381. ZHOU, H.; JIA, X.; YANG, F. Elevated nuclear phospho-eIF4E body levels are associated with tumor progression and poor prognosis for acute myeloid leukemia. Biocell 2021, 45, 711-722. [CrossRef]

382. Volpon, L.; Culjkovic-Kraljacic, B.; Osborne, M.J.; Ramteke, A.; Sun, Q.; Niesman, A.; Chook, Y.M.; Borden, K.L. Importin 8 mediates $\mathrm{m} 7 \mathrm{G}$ cap-sensitive nuclear import of the eukaryotic translation initiation factor eIF4E. Proc. Natl. Acad. Sci. USA 2016, 113, 5263-5268. [CrossRef]

383. Jia, X.F.; Zhou, H. Phospho-eIF4E: A new target for acute myeloid leukemia. Curr. Protein Pept. Sci. 2021, 22, 328-335. [CrossRef]

384. Chen, G.; Gharib, T.G.; Thomas, D.G.; Huang, C.C.; Misek, D.E.; Kuick, R.D.; Giordano, T.J.; Iannettoni, M.D.; Orringer, M.B.; Hanash, S.M.; et al. Proteomic analysis of eIF-5A in lung adenocarcinomas. Proteomics 2003, 3, 496-504. [CrossRef]

385. Ning, L.; Wang, L.; Zhang, H.; Jiao, X.; Chen, D. Eukaryotic translation initiation factor 5A in the pathogenesis of cancers. Oncol. Lett. 2020, 20, 81. [CrossRef] [PubMed]

386. Taylor, C.A.; Sun, Z.; Cliche, D.O.; Ming, H.; Eshaque, B.; Jin, S.; Hopkins, M.T.; Thai, B.; Thompson, J.E. Eukaryotic translation initiation factor $5 \mathrm{~A}$ induces apoptosis in colon cancer cells and associates with the nucleus in response to tumour necrosis factor alpha signalling. Exp. Cell Res. 2007, 313, 437-449. [CrossRef] [PubMed]

387. Moghanibashi, M.; Rastgar Jazii, F.; Soheili, Z.S.; Zare, M.; Karkhane, A.; Parivar, K.; Mohamadynejad, P. Esophageal cancer alters the expression of nuclear pore complex binding protein Hsc70 and eIF5A-1. Funct. Integr. Genomics 2013, 13, 253-260. [CrossRef]

388. Khosravi, S.; Martinka, M.; Zhou, Y.; Ong, C.J. Prognostic significance of the expression of nuclear eukaryotic translation initiation factor 5A2 in human melanoma. Oncol Lett. 2016, 12, 3089-3100. [CrossRef]

389. Khosravi, S.; Wong, R.P.; Ardekani, G.S.; Zhang, G.; Martinka, M.; Ong, C.J.; Li, G. Role of EIF5A2, a downstream target of Akt, in promoting melanoma cell invasion. Br. J. Cancer 2014, 110, 399-408. [CrossRef]

390. Dapas, B.; Tell, G.; Scaloni, A.; Pines, A.; Ferrara, L.; Quadrifoglio, F.; Scaggiante, B. Identification of different isoforms of eEF1A in the nuclear fraction of human T-lymphoblastic cancer cell line specifically binding to aptameric cytotoxic GT oligomers. Eur. J. Biochem. 2003, 270, 3251-3262. [CrossRef] [PubMed]

391. Dahl, L.D.; Corydon, T.J.; Rankel, L.; Nielsen, K.M.; Fuchtbauer, E.M.; Knudsen, C.R. An eEF1A1 truncation encoded by PTI-1 exerts its oncogenic effect inside the nucleus. Cancer Cell Int. 2014, 14, 17. [CrossRef] [PubMed] 
392. Veremieva, M.; Kapustian, L.; Khoruzhenko, A.; Zakharychev, V.; Negrutskii, B.; El'skaya, A. Independent overexpression of the subunits of translation elongation factor complex eEF1H in human lung cancer. BMC Cancer 2014, 14, 913. [CrossRef]

393. Allfrey, V.G. Amino acid incorporation by isolated thymus nuclei. I. the role of desoxyribonucleic acid in protein synthesis. Proc. Natl. Acad. Sci. USA 1954, 40, 881-885. [CrossRef]

394. Allfrey, V.G.; Mirsky, A.E. Protein synthesis in isolated cell nuclei. Nature 1955, 176, 1042-1049. [CrossRef] [PubMed]

395. Iborra, F.J.; Jackson, D.A.; Cook, P.R. Coupled transcription and translation within nuclei of mammalian cells. Science 2001, 293, 1139-1142. [CrossRef] [PubMed]

396. Dahlberg, J.E.; Lund, E.; Goodwin, E.B. Nuclear translation: What is the evidence? RNA 2003, 9, 1-8. [CrossRef]

397. Hentze, M.W. Protein synthesis. Believe it or not-translation in the nucleus. Science 2001, 293, 1058-1059. [CrossRef] [PubMed]

398. Nickless, A.; Bailis, J.M.; You, Z. Control of gene expression through the nonsense-mediated RNA decay pathway. Cell BioSci. 2017, 7, 26. [CrossRef]

399. Al-Jubran, K.; Wen, J.; Abdullahi, A.; Roy Chaudhury, S.; Li, M.; Ramanathan, P.; Matina, A.; De, S.; Piechocki, K.; Rugjee, K.N.; et al. Visualization of the joining of ribosomal subunits reveals the presence of $80 \mathrm{~S}$ ribosomes in the nucleus. RNA 2013, 19, 1669-1683. [CrossRef]

400. David, A.; Dolan, B.P.; Hickman, H.D.; Knowlton, J.J.; Clavarino, G.; Pierre, P.; Bennink, J.R.; Yewdell, J.W. Nuclear translation visualized by ribosome-bound nascent chain puromycylation. J. Cell Biol. 2012, 197, 45-57. [CrossRef]

401. Apcher, S.; Millot, G.; Daskalogianni, C.; Scherl, A.; Manoury, B.; Fahraeus, R. Translation of pre-spliced RNAs in the nuclear compartment generates peptides for the MHC class I pathway. Proc. Natl. Acad. Sci. USA 2013, 110, 17951-17956. [CrossRef]

402. Martins, R.P.; Malbert-Colas, L.; Lista, M.J.; Daskalogianni, C.; Apcher, S.; Pla, M.; Findakly, S.; Blondel, M.; Fahraeus, R. Nuclear processing of nascent transcripts determines synthesis of full-length proteins and antigenic peptides. Nucleic Acids Res. 2019, 47, 3086-3100. [CrossRef] [PubMed]

403. Duvallet, E.; Boulpicante, M.; Yamazaki, T.; Daskalogianni, C.; Prado Martins, R.; Baconnais, S.; Manoury, B.; Fahraeus, R.; Apcher, S. Exosome-driven transfer of tumor-associated Pioneer Translation Products (TA-PTPs) for the MHC class I cross-presentation pathway. Oncoimmunology 2016, 5, e1198865. [CrossRef]

404. Baboo, S.; Bhushan, B.; Jiang, H.; Grovenor, C.R.; Pierre, P.; Davis, B.G.; Cook, P.R. Most human proteins made in both nucleus and cytoplasm turn over within minutes. PLoS ONE 2014, 9, e99346. [CrossRef]

405. Boulpicante, M.; Darrigrand, R.; Pierson, A.; Salgues, V.; Rouillon, M.; Gaudineau, B.; Khaled, M.; Cattaneo, A.; Bachi, A.; Cascio, P.; et al. Tumors escape immunosurveillance by overexpressing the proteasome activator PSME3. Oncoimmunology 2020, 9, 1761205. [CrossRef] [PubMed]

406. Pierson, A.; Darrigrand, R.; Rouillon, M.; Boulpicante, M.; Renko, Z.D.; Garcia, C.; Ghosh, M.; Laiguillon, M.-C.; Lobry, C.; Alami, M.; et al. Splicing inhibition enhances the antitumor immune response through increased tumor antigen presentation and altered MHC-I immunopeptidome. bioRxiv 2019, 512681. [CrossRef]

407. Theodoridis, P.R.; Bokros, M.; Marijan, D.; Balukoff, N.C.; Wang, D.; Kirk, C.C.; Budine, T.D.; Goldsmith, H.D.; Wang, M.; Audas, T.E.; et al. Local translation in nuclear condensate amyloid bodies. Proc. Natl. Acad. Sci. USA 2021, 118. [CrossRef] [PubMed]

408. Lashkevich, K.A.; Dmitriev, S.E. mRNA Targeting, Transport and Local Translation in Eukaryotic Cells: From the Classical View to a Diversity of New Concepts. Mol. Biol. 2021, 55, 507-537. [CrossRef]

409. Bernhofer, M.; Goldberg, T.; Wolf, S.; Ahmed, M.; Zaugg, J.; Boden, M.; Rost, B. NLSdb-major update for database of nuclear localization signals and nuclear export signals. Nucleic Acids Res. 2018, 46, D503-D508. [CrossRef] [PubMed]

410. Nalabothula, N.; Indig, F.E.; Carrier, F. The Nucleolus Takes Control of Protein Trafficking Under Cellular Stress. Mol. Cell Pharmacol 2010, 2, 203-212.

411. Li, S. Regulation of Ribosomal Proteins on Viral Infection. Cells 2019, 8, 508. [CrossRef] [PubMed]

412. Roux, P.P.; Topisirovic, I. Signaling Pathways Involved in the Regulation of mRNA Translation. Mol. Cell Biol. 2018, 38, e00070-18. [CrossRef]

413. Xiong, W.; Lan, T.; Mo, B. Extraribosomal Functions of Cytosolic Ribosomal Proteins in Plants. Front. Plant. Sci. $2021,12,607157$. [CrossRef] [PubMed]

414. Luan, Y.; Tang, N.; Yang, J.; Chen, C.; Liu, S.; Cheng, C.; Wang, Y.; Guo, Y.-n.; Wang, H.; Xiang, M.; et al. Decoding regulatory specificity of human ribosomal proteins. bioRxiv 2021, 437302. [CrossRef]

415. Du, X.; Xiao, R. An emerging role of chromatin-interacting RNA-binding proteins in transcription regulation. Essays Biochem. 2020, 64, 907-918. [CrossRef] [PubMed]

416. Razin, S.V.; Gavrilov, A.A. Non-coding RNAs in chromatin folding and nuclear organization. Cell Mol. Life Sci. 2021, 78, 5489-5504. [CrossRef] [PubMed]

417. Chen, J.Y.; Lim, D.H.; Fu, X.D. Mechanistic Dissection of RNA-Binding Proteins in Regulated Gene Expression at Chromatin Levels. Cold Spring Harb. Symp. Quant. Biol. 2019, 84, 55-66. [CrossRef]

418. Balcerak, A.; Trebinska-Stryjewska, A.; Konopinski, R.; Wakula, M.; Grzybowska, E.A. RNA-protein interactions: Disorder, moonlighting and junk contribute to eukaryotic complexity. Open Biol. 2019, 9, 190096. [CrossRef]

419. Li, X.; Wang, X.; Cheng, Z.; Zhu, Q. AGO2 and its partners: A silencing complex, a chromatin modulator, and new features. Crit. Rev. Biochem. Mol. Biol. 2020, 55, 33-53. [CrossRef]

420. Sangermano, F.; Delicato, A.; Calabro, V. Y box binding protein 1 (YB-1) oncoprotein at the hub of DNA proliferation, damage and cancer progression. Biochimie 2020, 179, 205-216. [CrossRef] 
421. Kretov, D.A.; Mordovkina, D.A.; Eliseeva, I.A.; Lyabin, D.N.; Polyakov, D.N.; Joshi, V.; Desforges, B.; Hamon, L.; Lavrik, O.I.; Pastre, D.; et al. Inhibition of Transcription Induces Phosphorylation of YB-1 at Ser102 and Its Accumulation in the Nucleus. Cells 2019, 9, 104. [CrossRef]

422. Mordovkina, D.A.; Kim, E.R.; Buldakov, I.A.; Sorokin, A.V.; Eliseeva, I.A.; Lyabin, D.N.; Ovchinnikov, L.P. Transportin-1dependent YB-1 nuclear import. Biochem. Biophys. Res. Commun. 2016, 480, 629-634. [CrossRef]

423. Zanzoni, A.; Ribeiro, D.M.; Brun, C. Understanding protein multifunctionality: From short linear motifs to cellular functions. Cell Mol. Life Sci. 2019, 76, 4407-4412. [CrossRef] [PubMed]

424. Liu, H.; Jeffery, C.J. Moonlighting Proteins in the Fuzzy Logic of Cellular Metabolism. Molecules 2020, 25, 3440. [CrossRef]

425. Espinosa-Cantu, A.; Cruz-Bonilla, E.; Noda-Garcia, L.; DeLuna, A. Multiple Forms of Multifunctional Proteins in Health and Disease. Front. Cell Dev. Biol. 2020, 8, 451. [CrossRef] [PubMed]

426. Franco-Serrano, L.; Huerta, M.; Hernandez, S.; Cedano, J.; Perez-Pons, J.; Pinol, J.; Mozo-Villarias, A.; Amela, I.; Querol, E. Multifunctional Proteins: Involvement in Human Diseases and Targets of Current Drugs. Protein J. 2018, 37, 444-453. [CrossRef]

427. Gurevich, V.V. Protein multi-functionality: Introduction. Cell Mol. Life Sci. 2019, 76, 4405-4406. [CrossRef] [PubMed]

428. Slobodin, B.; Dikstein, R. So close, no matter how far: Multiple paths connecting transcription to mRNA translation in eukaryotes. EMBO Rep. 2020, 21, e50799. [CrossRef] [PubMed]

429. Lee, T.A.; Bailey-Serres, J. Integrative analysis from the epigenome through translation exposes patterns of dominant nuclear regulation during transient stress. Plant Cell 2019, 31, 2573-2595. [CrossRef]

430. Maciag, K.; Altschuler, S.J.; Slack, M.D.; Krogan, N.J.; Emili, A.; Greenblatt, J.F.; Maniatis, T.; Wu, L.F. Systems-level analyses identify extensive coupling among gene expression machines. Mol. Syst. Biol. 2006, 2, 2006.0003. [CrossRef] 